\title{
Geology and Uranium
}

Occurrences of the Northern

Half of the Lehighton

Pennsylvania, Quadrangle

And adjoining areas

$\begin{array}{lllll}\text { GE LOG I CAL SURVEY BULLETIN } & 1138\end{array}$

Prepared on behalf of the U.S. Atomic Energy Commission
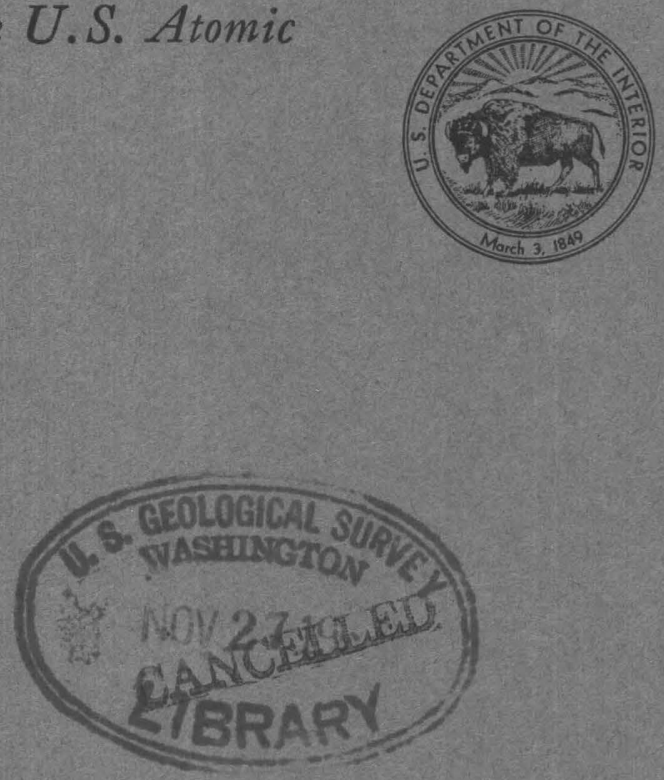



\section{Geology and Uranium}

\section{Occurrences of the Northern}

\section{Half of the Lehighton}

Pennsylvania, Quadrangle

\section{And adjoining areas}

By HARRY KLEMIC, JAMES C. WARMAN, and ALFRED R. TAYLOR

G E O L O G I C A L S U R V E Y B U L L E T I N 1138

Prepared on behalf of the U.S. Atomic Energy Commission

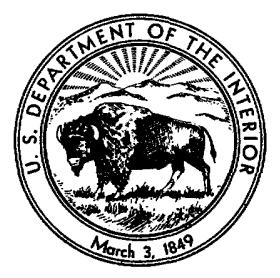


UNITED STATES DEPARTMENT OF THE INTERIOR

STEWART L. UDALL, Secretary

\section{GEOLOGIGAL SURVEY}

Thomas B. Nolan, Director

The U.S. Geological Survey Library catalog card for this publication appears after page 97. 


\section{CONTENTS}

\begin{tabular}{|c|c|}
\hline & Page \\
\hline & 1 \\
\hline 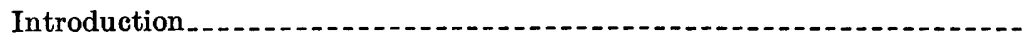 & 2 \\
\hline Purpose and scope of investigations & 2 \\
\hline Location and accessibility & 3 \\
\hline Physiography _........... & 3 \\
\hline Drainage & \\
\hline Glacial features & \\
\hline Climate and vegetation & 6 \\
\hline Field and laboratory methods & 7 \\
\hline Acknowledgments & 7 \\
\hline Previous geologic work & 8 \\
\hline Stratigraphy & 8 \\
\hline Stratigraphic nomenclature & 9 \\
\hline Middle Devonian series_...... & 10 \\
\hline Marcellus and Hamilton formations, undivided & 10 \\
\hline Upper Devonian series. & 13 \\
\hline group_... & 13 \\
\hline Trimmers Rock sandstone & 15 \\
\hline Catskill formation & 19 \\
\hline Walcksville sandstone member & 26 \\
\hline Beaverdam Run member. & 27 \\
\hline Damascus redbed member (Willard, 1939) & 28 \\
\hline Honesdale sandstone member (White, 1882) & 30 \\
\hline y Ridge redbed member (Willard, 1939) & 33 \\
\hline series & 37 \\
\hline ion & 37 \\
\hline Upper Mississippian series. & 44 \\
\hline formation & 44 \\
\hline Pennsylvanian system & 52 \\
\hline Pottsville formation & 52 \\
\hline Post-Pottsville rocks & 54 \\
\hline Unconsolidated Pleistocene and Recent surficial material & 55 \\
\hline Structure & 56 \\
\hline Folds & 57 \\
\hline Syncline near Jonesville & 57 \\
\hline Lehighton anticline & 57 \\
\hline Mount Pisgah-Call Mountain syncline & 58 \\
\hline Upper Wild Creek-Jonas anticline & 59 \\
\hline in anticline & 59 \\
\hline cline_-1-1- & 59 \\
\hline Bald Mountain-Unionville anticline & 60 \\
\hline Drakes Creek syncline & 60 \\
\hline Summer Mountain anticline & 60 \\
\hline Larrytown syncline_... & 60 \\
\hline
\end{tabular}


Structure-Continued $\quad$ Page

Pocono Plateau . . .

Relief of stress during folding

Bedding-plane slippage, faults, and drag folds_._. 61

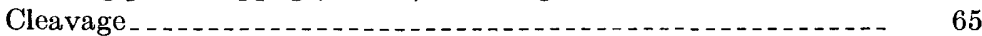

Joints_...

Fractures_...

Ellipsoidal structures_._.

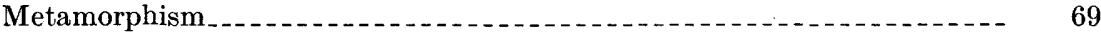

Geologic history

Paleontology

Water resources

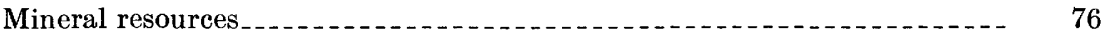

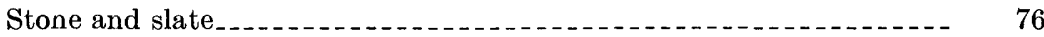

Coal

Uranium . .

Penn Haven Junction occurrences . _.

Uraniferous rock

Distribution and extent

Butcher Hollow occurrence

Mauch Chunk Ridge occurrence

Mount Pisgah occurrence._._.

Spectrographic analyses $\ldots$

Origin

Geochronology

Uranium potential

Galena, sphalerite, chalcopyrite, and pyrite $\ldots \ldots$

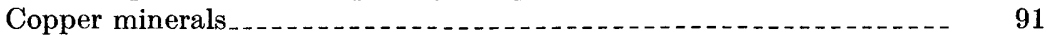

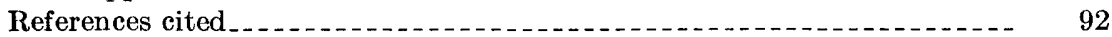

Index

\section{ILLUSTRATIONS}

[Plates are in pocket]

Plate 1. Geologic map showing uranium occurrences in the northern half of the Lehighton, Pennsylvania, quadrangle and some adjoining areas.

2. Sections and location map of some uranium occurrences in Carbon County, Pa.

Page

FIGURE 1. Index map showing location of the northern half of the Lehighton quadrangle and adjoining areas in Pennsylvania . .......

2. A. Sketch of bedding-plane slip surfaces, minor faults, joints, and fractures on the east face of a road cut along the northeastern extension of the Pennsylvania Turnpike near Walcksville, Carbon County, Pa. B. Sketch of faulted minor fold in the Bald Mountain-Unionville anticline exposed on the east side of Lehigh River along Lehigh Valley Railroad near Unionville, Carbon County, Pa. 


\section{TABLES}

Page

TABLE 1. Rock units in the northern part of the Lehighton, Pa., quadrangle and adjoining areas. . . . . . .

2. Generalized section of the Marcellus and Hamilton formations, undivided of Middle Devonian age along Wild Creek and along Pine Creek between Pohopoco Creek and Indian Hills

3. Measured section of part of the Trimmers Rock sandstone of Late Devonian age exposed in a roadcut along the northeastern extension of the Pennsylvania Turnpike near Walcksville, Carbon County, Pa.

4. Measured sections of members of the Catskill formation, of Late Devonian age, in Carbon County, $\mathrm{Pa}$

5. Section of Pocono formation of Early Mississippian age near Jim Thorpe, Carbon County, Pa., measured along base of Bear Mountain, south of Lehigh Valley Railroad station on east side of Lehigh River

6. Section of Mauch Chunk formation of Late Mississippian age near Jim Thorpe, Carbon County, $\mathrm{Pa}$

7. Generalized description of the Pottsville formation of Early Pennsylvanian age and the post-Pottsville rocks on Mount Pisgah near Jim Thorpe, Carbon County, Pa. . . . . . . . -

8. Devonian marine fossils from the northern part of the Lehighton Pa., quadrangle and some adjoining areas and localities in

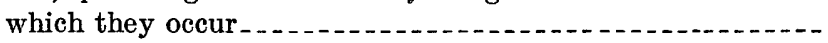

9. Composition of thin sections of uraniferous rock of the Catskill formation near Penn Haven Junction, Carbon County, $\mathrm{Pa}$

10. Results of spectrographic and chemical analyses of uraniferous rock from uranium occurrences in Carbon County, $\mathrm{Pa} . . . . .-$

11. Semiquantitative spectrographic analysis of a sample of galena from fracture fillings in Upper Devonian rocks near Walcksville, Carbon County, $\mathrm{Pa}_{\ldots} \ldots$ 


\title{
GEOLOGY AND URANIUM OGGURRENGES OF THE NORTHERN HALF OF THE LEHIGHTON, PENNSYL- VANIA, QUADRANGLE AND ADJOINING AREAS
}

\author{
By Harry Klemic, James C. Warman, and Alfred R. Taylor
}

\section{ABSTRACT}

The most promising uranium occurrences found in the Eastern United States are in the northern half of the Lehighton, Pa., quadrangle and adjoining areas to the west and south. About 157 square miles surrounding the occurrences, in Carbon and Monroe Counties in the Valley and Ridge and Appalachian Plateaus physiographic provinces, were mapped.

The entire area is drained by the Lehigh River and its tributaries, and a thick section of the underlying rock formations crops out along the gorge of the river. The uranium occurrences are also exposed along the river.

The oldest rocks exposed are the Marcellus and Hamilton formations, undivided, of Middle Devonian age, consisting of about 1,700 feet of gray marine shale and slate. The Susquehanna group of Late Devonian age, which overlies the Marcellus and the Hamilton, consists of gray marine sandstone, siltstone, and shale of the Trimmers Rock sandstone, about 1,300 feet thick, and predominantly nonmarine beds of the Catskill formation, about 7,400 feet thick. The Catskill is divided into five members: from bottom to top, the Walcksville sandstone member, which consists of almost 700 feet of red and gray nonmarine beds; gray marine sandstone and siltstone of the Beaverdam Run member, about 900 feet thick; the Damascus redbed member (Willard, 1939), about 3,100 feet thick; the gray Honesdale sandstone member (White, 1882), about 1,700 feet thick; and the red and gray Cherry Ridge redbed member (Willard, 1939), about 950 feet thick. Rocks of the Trimmers Rock sandstone are low-rank graywacke and shale; those of the Catskill formation are low-rank graywacke and quartzite.

Nonmarine gray sandstone of the Pocono formation of Early Mississippian age conformably overlies the Catskill formation. The Pocono is divided into a lower member that is $\mathbf{4 0 0}$ feet thick and an upper member that is about 700 feet thick. The rocks of the Pocono are low-rank graywacke and quartzites. The overlying Mauch Chunk formation of Late Mississippian age is about 2,200 feet thick. Low-rank and high-rank graywacke and thin calcareous beds make up the Mauch Chunk. The lower 1,700 feet is mostly red beds. The upper part of the formation is the Mauch Chunk-Pottsville transition zone, which consists of about 500 feet of red and gray beds with a thick uraniferous basal bed of gray conglomerate and sandstone. Overlying the Mauch Chunk is about 900 feet of conglomerate and low-rank graywacke sandstone, which make up the Pottsville formation of Early Pennsylvanian age. The youngest rocks in the area are post-Pottsville rocks of Pennsylvanian age. They are mostly gray sandstone but contain some thin beds of anthracite coal and underclay. Glacial till of preWisconsin age and colluvium partly mask the bedrock.

The rocks are folded into northeastward-trending synclines and anticlines except in the northeastern part of the area, which is considered a part of the 
Pocono Plateau. The beds there dip moderately to the northwest along the escarpment of the plateau.

Bedding-plane slip or fault surfaces are numerous, and displacement along bedding planes is believed to have been a major mechanism for adjustment of stresses due to folding. Some zones of bedding-plane slippage in the Ponoco formation may actually be faults of considerable displacement. Minor intraformational faults occur. Flow cleavage is well developed in the Marcellus and Hamilton formations because the rocks were homogeneous and reacted to the stresses as a single unit, whereas the interlayered fine- and coarse-grained beds of the younger formations adjusted by slippage along bedding planes and by development of fracture cleavage in thin shale beds.

Joint sets that trend about N. $65^{\circ}$ E., N. $30^{\circ}$ W., and N. $20^{\circ}$ E. are well developed.

Uranium occurs in the Cherry Ridge member of the Catskill formation near Jim Thorpe, near Butcher Hollow about 4 miles north of Jim Thorpe, and near Penn Haven Junction. Uraninite and clausthalite in tiny particles are closely associated in the Penn Haven Junction occurrence. The uranium follows and cuts across bedding and follows roll structures. Secondary uranium minerals and a black uranium mineral occur in small amounts along Mauch Chunk Ridge, and secondary uranium minerals have been found at the Butcher Hollow occurrence.

Uranium in tiny black particles is locally abundant in the basal conglomerate of the Mauch Chunk-Pottsville transition zone on the north side of the nose of Mount Pisgah. The uranium follows and cuts across bedding or follows roll structures. There are zones of fractures or shear zones in the mineralized rock. Calcite cement seals the rock. Weathered zones contain carnotite, tyuyamunite, and other secondary uranium minerals.

The uranium is believed to have been concentrated epigenetically, in Pennsylvanian or post-Pennsylvanian time, prior to the jointing, from uranium that was deposited syngenetically in the formations.

Uranium-lead studies of uraniferous sandstone from the Mauch ChunkPottsville transition zone give a calculated age of about 135 million years. Studies of uraniferous sandstone containing clausthalite from the Penn Haven Junction uranium occurrence give a calculated concordant age of $\mathbf{1 1 5}$ million years.

The uranium deposits near Penn Haven Junction and on Mount Pisgah are worthy of further development work if the need for uranium becomes greater and if marketing conditions in northeastern United States become more favorable.

\section{INTRODUCTION}

\section{PURPOSE AND SCOPE OF INVESTIGATIONS}

The most promising uranium occurrences found in the Eastern United States are in part of Carbon County, Pa. In 1955, geologic mapping of the northern half of the Lehighton, Pa., quadrangle and adjoining areas to the west and south was undertaken to evaluate and understand the uranium potentialities. Detailed studies of lithologic units and of uranium occurrences were made in the field. Laboratory analyses supplemented the field studies. This report presents the results of geologic mapping and investigations of the Lehighton, Pa., quadrangle area from mid-1955 to mid-1958. 


\section{LOCATION AND ACCESSIBILITY}

The area described in this report is in Carbon and Monroe Counties in east-central Pennsylvania (fig. 1), about 70 miles northwest of Philadelphia. Its eastern border is at long $75^{\circ} 30^{\prime} \mathrm{W}$. and extends from lat $40^{\circ} 50^{\prime} 30^{\prime \prime} \mathrm{N}$. to $41^{\circ} 00^{\prime} \mathrm{N}$. The western border is at long $75^{\circ} 46^{\prime} \mathrm{W}$. between lat $40^{\circ} 50^{\prime} 30^{\prime \prime} \mathrm{N}$. and $41^{\circ} 00^{\prime} \mathrm{N}$. The area shown on the geologic map (pl. 1) includes about 157 square miles.

The town of Jim Thorpe (formerly Mauch Chunk), county seat of Carbon County, has about 5,000 residents and is the largest community in the area. The village of Nesquehoning is a few miles to the west, Albrightsville lies to the north, and the town of Lehighton is immediately south of the area. The village of Kresgeville is on the eastern boundary.

Most of the area is readily accessible by good roads and the remainder by timber roads, firebreaks, utility-line clearings, and trails. U.S. Routes 209 and 309, Pennsylvania Routes 903 and 45, the northeastern extension of the Pennsylvania Turnpike, and several county roads cross the area. The main lines of the Central Railroad of New Jersey and the Lehigh Valley Railroad Co., Inc., cross the western part of the area with stations at the town of Jim Thorpe.

Railroad maintenance is the major industry, but there is some farming and there are a few small garment factories and other light industries in the area. Many of the workers are employed in manufacturing, coal mining, or railroad industries in nearby communities. The population of the area is greatest in the south and the northern part is only sparsely inhabited.

\section{PHYSIOGRAPHY}

The Lehighton quadrangle is in the Valley and Ridge province, but a small area in the northeastern corner may be considered a part of the Pocono Plateau of the Plateaus province, or a zone of merging of the provinces. In the southern and central parts of the quadrangle, the terrain consists of parallel valleys and ridges with about 1,000 feet of relief. The northern part of the quadrangle is an upland area with about 500 to 800 feet of relief between the ridges and valleys, and 1,000 feet of relief between the gorge of the Lehigh River and the tops of some of the adjoining highlands. Maximum relief in the area shown on plate 1 is about 1,500 feet, from a high of a little more than 1,960 feet on Stony Ridge in Penn Forest Township to a low between 480 and 460 feet above sea level in the valley of the Lehigh River near Jamestown.

The northeastward-trending ridge that makes up Bear Mountain, Call Mountain, and Pohopoco Mountain forms the southern escarpment of the Pocono Plateau. The crest of this ridge is roughly con- 


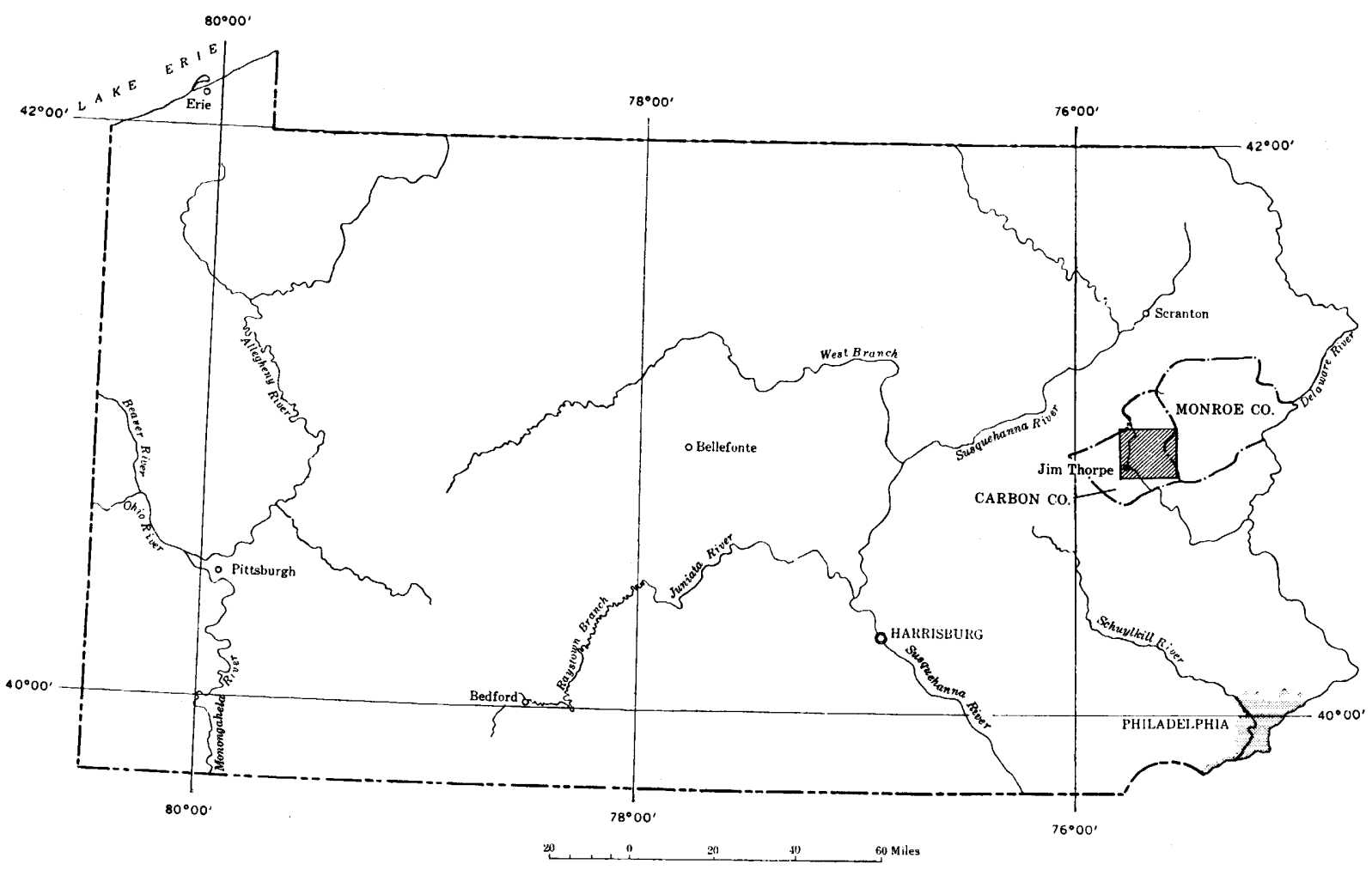

FIGURE 1.-Index map showing location of the northern half of the Lehighton quadrangle and adjoining areas in Pennsylvania. 
cordant with the crests of other ridges to the north and south. Ashley (1935, p. 1395-1436) described these ridges as part of the Schooley peneplane, which he considered to be of late Pliocene age (p. 1436) because gravels believed to be of Pliocene age lie on surfaces interpreted as the Schooley peneplane in southeastern Pennsylvania.

\section{DRAINAGE}

The Lehigh River and its tributaries drain the entire area. In crossing the 11 miles from the northern to the southern boundary of the area shown on plate 1 , the river drops from about 1,000 feet to about 470 feet above sea level and follows a tortuous route about 23 miles long. In places it cuts through resistant formations, crossing folds at Unionville, at Broad Mountain, and at Jim Thorpe, and in places it turns abruptly to follow along the strike of less resistant formations, paralleling synclines near Penn Haven Junction and Jim Thorpe . Its canyon is as deep as 1,000 feet.

Pohopoco Creek, Nesquehoning Creek, Black Creek, and Mud Run are major streams that follow the trends of regional structures. Drakes Creek and Stony Creek are smaller streams that follow synclinal valleys, and Bear Creek is cut into a flexure of the eastern extension of the Broad Mountain anticline. The upper part of Wild Creek, north of Call Mountain, and Pinoak Run, north of Pohopoco Mountain, flow eastward away from the Lehigh River along the trend of structures before turning south to join Pohopoco Creek, which flows southwestward along the Lehighton anticline to Lehigh River.

In the northern part of the area there are swamps in structural lows at altitudes of about 1,500 to 1,700 feet above sea level. Panther Creek, Drakes Creek, Stony Creek, Bear Creek, Pinoak Run, Wolf Run, and Carpsrocus Creek originate in such swamps. Their waters are dark from decayed organic material.

The straight stretches of the Lehigh River and of many of the smaller streams that flow almost perpendicular to the trend of regional folds are roughly parallel to a regional set of joints that trend northnorthwest. The direction and depth of incision of these stream valleys may have been greatly influenced by this joint system.

\section{GLACIAL Features}

The Lehighton quadrangle is within the area that was covered by Quaternary glaciers. The borders of the Jerseyan drift as shown on the geologic map of Pennsylvania (Stose and Ljungstedt, 1931) are south of the mapped area and the borders of the Illinoian drift cross the area just south of Pohopoco Creek. The Wisconsin-age drift border is a short distance north of the mapped area.

The principal glacial features are deposits of till in some local low places and the absence of a mantle of soil in some high places. No 
glacial erratics of igneous or high-grade metamorphic rocks have been found in the area by the authors.

Runoff waters, particularly from the Wisconsin glacial stage, probably did a large amount of the downcutting in the stream valleys in the northern part of the area, for many of the stream valleys are in a youthful stage, with precipitous sides, many waterfalls, and steep gradients in their lower parts near the Lehigh River.

\section{CHIMATE AND VEGETATION}

Within the Lehighton quadrangle there are noticeable climatic differences due to the physiographic features of the terrain. The northern part of the quadrangle and the adjoining areas to the north and west are predominantly upland plateau and valley and ridge terrain, whereas the southern part and its adjoining areas, except along narrow ridges, are generally 400 feet or more lower. Climatic information (U.S. Weather Bureau, $1930 ; 1958$ ) taken at weather stations at $\mathrm{Jim}$ Thorpe, altitude approximately 600 feet, in the southern part of the mapped area and Mount Pocono, Monroe County, Pa. (alt 1,658 ft), the nearest weather station to the upland region in the northern part, ${ }^{1}$ indicates that the average annual temperature is about $5^{\circ}$ lower in the upland region.

The upland areas have a short growing season and farming there is limited mostly to dairying and potato growing, whereas more general farming is done in the lower parts. The cool upland region around Lake Harmony, a short distance to the north is becoming increasingly popular as a summer resort.

Most of the ridges and the highlands not under cultivation are forested with deciduous trees or are brush covered. Pine, spruce, and hemlock grow in swamps and in hollows, but large stumps of conifers are all that remain of the evergreen forests that once gave the northern area the local nickname pine swamps. Poor soil and frequent forest fires have slowed the growth of new timber on the mountains, and large sections are choked with scrub oak, mountain laurel, and huckleberry bushes. Rhododendron thickets line the streams and moist places in hollows and in swamps where the timber has been removed.

In some areas where forest fires have been checked, the hardwood forests have outgrown the scrub oak, and fine stands of oak, maple, and beech are developing. Reforestation by planting of conifers has been done near the Wild Creek reservoir and in other small sections of the northern part of the Lehighton quadrangle, but most of the timbered or burned-over areas are left to natural reforestation.

\footnotetext{
1 Records for Mauch Chunk (Jim Thorpe) are from 1889 to 1952, for Mount Pocono 1901-52.
} 


\section{FIELD AND IABORATORY METHODS}

Geologic mapping was done on aerial photographs, on enlargements of the topographic map of the Mauch Chunk quadrangle, and on maps of the Weatherly and Nesquehoning quadrangles, which adjoin the Lehighton quadrangle to the west. Stratigraphic units were defined on the basis of megascopic physical differences. The boundaries of units that differ gradationally from adjoining units were selected arbitrarily. Both megascopic and microscopic examinations were made of rock samples in the laboratory and about 240 thin sections of rock were examined under the petrographic microscope. Clay mineral fractionation and X-ray spectrometer analyses were used in identification of the clay-sized components of the rocks. Spectrographic, radiometric, and chemical analyses were made of selected samples of rocks and minerals for determination of uranium, selenium, and other minor elements.

Portable scintillation counters and Geiger counters were used in the search for uranium. Drill eore from test drilling along the right-ofway of the northeastern extension of the Pennsylvania Turnpike and from test drilling for uranium on Pocono Mountain was logged for radioactivity and for stratigraphic information. An area near Penn Haven Junction was mapped topographically and detailed sketches were made of the distribution of radioactive rock with respect to bedding plane and cross fractures and to joints.

\section{ACKNOWLEDGMENTS}

The cooperation of individual and corporate property owners in the Lehighton quadrangle area is gratefully acknowledged. Permission granted by the Lehigh Valley Railroad Co., Inc., The Trojan Powder Co., and State game protectors in Carbon County to use access roads in the area greatly facilitated the work. Engineers and geologists of the Pennsylvania Turnpike Commission permitted access to drill cores and information about test drilling along the turnpike. Personnel of the Lehigh Coal and Navigation Co. were very helpful. Mr. Raymond Zimmerman and Mr. S. Behrens permitted the examination of cores from test drilling on Pocono Mountain.

A better understanding of some features of the local geology was obtained in conferences with Drs. Bradford Willard and H. R. Gault, of Lehigh University, and Dr. J. L. Dyson, of Lafayette College. F. A. Fitch 3d assisted in the fieldwork in 1957. All analyses of samples were made by the U.S. Geological Survey.

These studies were made by the U.S. Geological Survey on behalf of the Division of Raw Materials of the U.S. Atomic Energy Commission. 


\section{PREVIOUS GEOLOGIC WORK}

Geologic studies in the Lehighton quadrangle area date back to the First Pennsylvania Survey, and the stratigraphic system of numbered formations set up by Rogers (1836) was based in part on observations of rocks exposed along the Lehigh River. Studies of the geology of Carbon County, of the Lehigh River section, and of the southern anthracite field, which has its eastern end at Jim Thorpe, were made by the Second Pennsylvania Survey (Ashburner, 1883, 1884; Lesley, 1885; White, 1882; Winslow, 1887). Additional geologic information about this area was compiled by the Fourth Pennsylvania Survey under the direction of G. H. Ashley (Willard, 1939) and by the U.S. Geological Survey in cooperation with the Pennsylvania Survey (Lohman, 1937).

Devonian formations in eastern Pennsylvania were described by Willard (1935, 1936). White (1934) and Leonard ${ }^{2}$ described the Pocono formation, and Stevenson (1902), Barrell (1907, 1935), and Gault and others (1957) studied the Mauch Chunk. White (1900) and Grabau (1908) studied the Pottsville formation. Johnson (1931) and Ashley (1935) contributed information on the physiography of the region.

Uranium in the Mauch Chunk (Jim Thorpe) area was known as early as 1875 (Genth, 1875), and it has been studied and described by Wherry (1912, 1915), McKeown (unpublished data, 1949), Klemic and Baker (1954), Montgomery (1954), Dyson (1954), McCauley (1957), and Klemic (1962).

\section{STRATIGRAPHY}

The rock formations exposed in the central part of the Lehighton quadrangle range in age from Middle Devonian to Early Pennsylvanian and total about 14,700 feet in thickness. The oldest formations are marine fine-grained clastic sedimentary rocks with some thin calcareous zones. A section of marine beds is interlayered with a nonmarine sequence that makes up more than half of the Upper Devonian section. The overlying Mississippian and Lower Pennsylvanian formations are all continental sedimentary rocks. A mantle of unconsolidated colluvial sediments from Quaternary glacial and residual sources obscures the bedrock in most of the valley areas.

The major rock units in the northern part of the Lehighton quadrangle are given in table 1 and are described in more detail in the text.

2 Leonard, A. D., 1953, The Pocono sandstone neighboring the northern anthracite basin, Pennsylvania, a thesis: The Pennsylvania State College, Graduate School, Dept. of Earth Sciences, p. 1-27. 
TABLE 1.-Rock units in the northern part of the Lehighton, Pa., quadrangle and adjoining areas

\begin{tabular}{|c|c|c|c|c|c|}
\hline \multicolumn{2}{|c|}{ System or series } & Group & Formation & $\begin{array}{c}\text { Thickness } \\
\text { (feet) }\end{array}$ & Character and distribution \\
\hline \multicolumn{2}{|r|}{ Quaternary } & & & $0-50$ & $\begin{array}{l}\text { Unconsolidated glacial till and col- } \\
\text { luvial material. Widespread. }\end{array}$ \\
\hline \multirow{3}{*}{ 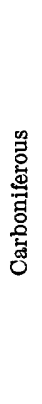 } & Pennsylvanian & & $\begin{array}{l}\text { Post-Pottsville rocks } \\
\text { Pottsville formation }\end{array}$ & $\begin{array}{r}75 \pm \\
900 \pm\end{array}$ & $\begin{array}{l}\text { Thin beds of sandstone, siltstone, } \\
\text { coal, and underclay. Exposed in } \\
\text { strip mine in southwestern corner } \\
\text { of project area. } \\
\text { Conglomeratic ridge-forming unit. } \\
\text { Underlies small area in south- } \\
\text { western corner of project area. }\end{array}$ \\
\hline & $\begin{array}{c}\text { Upper } \\
\text { Mississippian }\end{array}$ & & $\begin{array}{l}\text { Mauch Chunk } \\
\text { formation }\end{array}$ & $2,200 \pm$ & $\begin{array}{l}\text { Predominantly red bed unit with red } \\
\text { and gray transition zone at top. } \\
\text { Widespread in western part of area. } \\
\text { Less resistant than adjoining units. }\end{array}$ \\
\hline & $\begin{array}{c}\text { Lower } \\
\text { Mississippian }\end{array}$ & & Pocono formation & $1,100 \pm$ & $\begin{array}{l}\text { Conglomeratic in upper member, } \\
\text { sandy in lower member. Gray } \\
\text { ridge-forming formation. Wide- } \\
\text { spread in western part of project } \\
\text { area. }\end{array}$ \\
\hline \multicolumn{2}{|c|}{ Upper Devonian } & 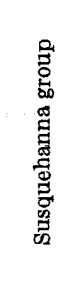 & $\underset{\substack{\text { Trimmers Rock } \\
\text { Sandstone }}}{\text { Tan }}$ & $7,400 \pm$ & $\begin{array}{l}\text { Five members, top to bottom: } \\
\text { Cherry Ridge redbed member } \\
\text { (Willard, 1939). Honesdale sand- } \\
\text { stone member (White, 1882) gray. } \\
\text { Damascus redbed member (Wil- } \\
\text { lard, 1939). Beaverdam Run mem- } \\
\text { ber, gray, marine. Walcksville } \\
\text { sandstone member, red and gray, } \\
\text { nonmarine. Formation widespread. } \\
\text { Fine-grained sandstone and silt } \\
\text { stone with marine fossils. wide- } \\
\text { spread in southeastern part of } \\
\text { project area. }\end{array}$ \\
\hline \multicolumn{2}{|c|}{ Middle Devonian } & & $\begin{array}{l}\text { Hamilton formation } \\
\text { and Marcellus shale, } \\
\text { undivided }\end{array}$ & $1,700 \pm$ & $\begin{array}{l}\text { Undivided marine gray and gray- } \\
\text { black shale with well-dereloped } \\
\text { cleavage. Southwestern part of } \\
\text { project area. }\end{array}$ \\
\hline
\end{tabular}

\section{STRATIGRAPHIC NOMENCLATURE}

The stratigraphic names used in this report are largely those used previously by geologists mapping in eastern Pennsylvania, but some new names are proposed. Willard's names (1939) for upper Devonian rock units are used as they are considered applicable to the local formations, but his correlations of Devonian rock units with rocks at type localities outside the mapped area have not been confirmed by the authors. The rocks of the Catskill formation and underlying rocks above the Marcellus and Hamilton formations are included in the Susquehanna group in accordance with the nomenclature that has been adopted for the revised geologic map of Pennsylvania by the Pennsylvania Bureau of Topographic and Geological Survey, 1960. The lower part of the Trimmers Rock member of the Fort Littleton formation of the Portage group of Willard (1939), as mapped along the Lehigh River, is included in the Susquehanna group 
as the Trimmers Rock sandstone. The upper part is divided into two members, the Walcksville sandstone member and the Beaverdam Run member. These are assigned to the Catskill formation.

Upper and lower as applied to the members of the Pocono formation are used in a restricted sense for units that are distinctive in the project area. If these units are shown to maintain their characteristics over much broader areas, geographic locality names should be assigned.

The top of the Mauch Chunk formation is placed at the top of the uppermost red bed and below the gray sandstone and conglomerate of the Tumbling Run member of the Pottsville formation as described by Wood and others (1956). Although this designation of the Mississippian-Pennsylvanian boundary is somewhat arbitrary in that it places more than 200 feet of beds similar to the Pottsville within the Mauch Chunk formation, it is consistent in that it places about an equal thickness of red beds within the predominantly red Mauch Chunk formation.

\section{MIDDLE DEVONIAN SERIES}

MARCELLUS AND HAMILTON FORMATIONS, UNDIVIDED

The lowest major stratigraphic unit exposed in the project area comprises the Marcellus shale and Hamilton formation, undivided. It consists of marine gray and gray-black shale and slate and silty, sandy, and calcareous bioherms. A generalized section of these rocks is given in table 2. The Marcellus and Hamilton formations have not been differentiated on the map (pl. 1). Fossils assigned to the Hamilton and Marcellus formations (G. O. Cooper, written communication, 1958) have been collected in the mapped area from rocks included in this unit.

The basal part of the Marcellus and Hamilton sequence consists of gray-black fissile or slaty shale that is sparsely fossiliferous. This grades upward into silty and sandy shale that is almost barren of fossils. Gray silty and sandy calcareous bioherms with intervening dark-gray shale overlie the more barren shale. Willard (1939, p. 178) correlated the bioherms with the Centerfield limestone of New York and designates them the Centerfield coral zone. Above the bioherms, slaty gray-black shale with thin calcareous fossiliferous layers make up the upper part of the section. This shale and perhaps its fossil fauna correspond to the Moscow, Ludlowville, and Skaneateles facies of Willard's Mahantango formation (1939, p. 161-200), overlying the Marcellus. In the project area, however, except at the bioherms, the changes in rock type generally are gradational or the rock types are interlayered, so that there are no precisely mappable lithologic boundaries to the units. 
TABLE 2.-Generalized section of the Marcellus and Hamilton formations, undivided of Middle Devonian age along Wild Creek and along Pine Creek between Pohopoco Creek and Indian Hills

\begin{tabular}{|c|c|c|c|c|}
\hline \multirow{2}{*}{ Rock type } & \multirow{2}{*}{ Color } & \multirow{2}{*}{ Remarks } & \multicolumn{2}{|c|}{$\begin{array}{l}\text { Thickness } \\
\text { (in feet) }\end{array}$} \\
\hline & & & Unit & Total \\
\hline Shale, siltstone_- & Dark gray _. - & $\begin{array}{l}\text { Well-developed cleavage; } \\
\text { bedding mostly obscure; } \\
\text { marine fossils abundant in } \\
\text { some layers; nodular, silty, } \\
\text { and calcareous layers. }\end{array}$ & $850 \pm$ & $850 \pm$ \\
\hline Siltstone, shale & $\underset{\text { gray }}{\text { Medium }}$ & $\begin{array}{l}\text { Bioherm, partly calcareous; } \\
\text { cleavage not so well devel- } \\
\text { oped as in overlying and } \\
\text { underlying rocks. }\end{array}$ & $60 \pm$ & $910 \pm$ \\
\hline Do......... & Dark gray -- & $\begin{array}{l}\text { Well-developed cleavage, ob- } \\
\text { scure bedding, silty and } \\
\text { shaly layers with marine } \\
\text { fossils, but mostly un- } \\
\text { fossiliferous or sparsely } \\
\text { fossiliferous. Fossils de- } \\
\text { formed by cleavage, con- } \\
\text { cealed intervals. }\end{array}$ & $750 \pm$ & $1,660 \pm$ \\
\hline Shale, siltstone _- & $\begin{array}{l}\text { Dark gray } \\
\text { to black. }\end{array}$ & $\begin{array}{l}\text { Slaty cleavage, fissile and } \\
\text { hackly fracture, sparsely } \\
\text { fossiliferous; fossils de- } \\
\text { formed by cleavage; vary- } \\
\text { ing apparent dips suggest } \\
\text { minor structures, but con- } \\
\text { cealed intervals and un- } \\
\text { reliable dip measurements } \\
\text { due to possible slumping } \\
\text { and obscure bedding pre- } \\
\text { vent precise determination } \\
\text { of structures. }\end{array}$ & $100 \pm$ & $1,760 \pm$ \\
\hline
\end{tabular}

The top of the Marcellus and Hamilton sequence in the project area is placed where the gray-black shale grades into a sandy and shaly facies of the Trimmers Rock sandstone which crops out on the hill south of Pohopoco Creek and on the south side of Indian Hills. A silty calcareous zone that is a few feet thick and contains fossils assigned to the Tully formation of Late Devonian age (Willard, 1939, p. 207) or perhaps of late Middle Devonian age (Cooper and Williams, 1935, p. 824) is interlayered with the dark-gray shale less than 50 feet stratigraphically below the more sandy beds of the Trimmers Rock. This zone has not been mapped as a separate unit. Ideally, it may be used as a marker for the boundary between the Marcellus and Hamilton sequence and the Trimmers Rock, but colluvial material from the more resistant sandy beds of the Trimmers Rock, which crop out 
on higher ground, obscures the contact, and the position of the Tullyequivalent zone is, in most places, difficult or impossible to locate at the surface.

\section{Composition}

The composition of the dark shale and slate of the Marcellus and the Hamilton, as determined by examination under the petrographic microscope and by megascopic examination, appears to be similar to that of typical black shale and slate in adjoining areas (Behre, 1933, p. 173-184). Illite and chlorite, the most abundant minerals, are in the clay-size fraction, but a few larger sheaves of mica and chlorite were seen in most of the thin sections that were studied. In some sections the micaceous flakes are alined parallel to cleavage, but in others the alinement is not well developed.

Quartz is the most abundant of the granular minerals in the thin sandy and silty layers. The quartz as seen in thin section is in wellsorted equant to subequant grains and has angular irregular outlines and wavy extinction. No secondary overgrowths were noted, but elongate patches of interlocking quartz grains surround relict fossil structures. Chert is next in abundance to quartz and has the same general outline as the quartz. Dolomite or calcite, in particles that may be fragments of fossils and as a cementing material, is the next most abundant material in sections of the fossiliferous rocks.

Feldspar in albite-twinned grains with low extinction angles was noted in a few thin sections. The grains are subequant and angular in shape. Only a few grains of feldspar were recognized in any of the sections. The micaceous minerals overlap the very fine grains of quartz, feldspar, and other minerals and make identification of the feldspar very difficult. If untwinned feldspar were present in the shaly rocks, it would be difficult or impossible to identify by optical means.

Zircon and black opaque minerals in small subrounded equant grains are accessories in some of the sandy layers.

A brown material that is probably iron oxide in an amorphous or submicroscopic form and minute black particles that may be graphite darken the rock.

The clay-size mineral components of these rocks are quartz, illite (of the $2 \mathrm{M}$ muscovite type), chlorite, $\mathrm{Fe}_{2} \mathrm{O}_{3}$, and possibly dolomite. The clay-sized components of the rock units in the project area were studied by X-ray spectrometer methods and are discussed in a later section. (See p. 69.)

\section{Distribution}

The undivided sequence of the Marcellus and the Hamilton formations in the project area is exposed at the surface only in the area 
between Indian Hills and the ridge on the south side of Pohopoco Creek (pl. 1, south part); elsewhere, it is overlain by younger formations. The rocks of the Marcellus and the Hamilton are cleaved and jointed and apparently are less resistant than the overlying Trimmers Rock; therefore, the Marcellus and Hamilton sequence underlies a relatively low area and is mostly concealed by overburden. The section is best exposed along Wild Creek and Pine Creek between Pohopoco Creek and the Indian Hills and along Pohopoco Creek, but even along the steep sides of these streans the rocks are poorly exposed for long stretches. The homogeneity of the rock, the closely spaced cleavage, and the possibility that many of the outcrops have been disoriented by slumping make it difficult to determine the attitude of the bedding and to measure the thickness of the section accurately. The calcareous bioherms and a few shaly beds crop out in fields, but most of the Marcellus and Hamilton sequence is concealed in its outcrop area. The outcrop area of a formation as used here means the area in which a given formation is the bedrock nearest the surface. The rocks may crop out, or they may be covered only by unconsolidated surficial material.

\section{UPPER DEVONIAN SERIES}

\section{SUSQUEHANNA GROUP}

The Susquehanna group of Late Devonian age overlies the Marcellus and Hamilton formations and underlies the Pocono formation. It is equivalent to the Susquehanna series of Ashley (1923). In the Lehighton quadrangle the Susquehanna group, here adopted by the U.S. Geological Survey, has been divided into the following units:

\section{Catskill formation:}

Cherry Ridge redbed member (Willard, 1939)

Honesdale sandstone member (White, 1882)

Damascus redbed member (Willard, 1939)

Beaverdam Run member

Walcksville sandstone member

Trimmers Rock sandstone

These units have an aggregate thickness of about 8,700 feet.

The main body of the Catskill formation has been generally recognized by geologists who have examined the Lehigh River section, but the rocks here included in the Trimmers Rock sandstone and in the Walcksville and Beaverdam Run members of the Catskill formation have been described under different names. A tentative correlation is given as follows: 


\begin{tabular}{|c|c|c|c|}
\hline & $\begin{array}{l}\text { Lehigh River south of } \\
\text { Packerton }\end{array}$ & \multicolumn{2}{|c|}{ Pike and Monroe Counties } \\
\hline & $\begin{array}{l}\text { White (1881, p. 68-74; } \\
\text { 1882, p. 98-107) }\end{array}$ & \multicolumn{2}{|c|}{$\begin{array}{c}\text { Willard }(1935, \text { p. } 1195-1218 ; 1936, \text { p. } 567-607 ; 1939, \text { p. } \\
210-295)\end{array}$} \\
\hline $\begin{array}{l}\text { Beaverdam Run member } \\
\text { of Catskill formation. }\end{array}$ & Delaware River flags. & \multirow[t]{3}{*}{$\begin{array}{l}\text { Trimmers Rock sand- } \\
\text { stone of Fort Littleton } \\
\text { formation of Portage } \\
\text { group. }\end{array}$} & Delaware River flags. \\
\hline $\begin{array}{l}\text { Walcksville sandstone } \\
\text { member of Catskill for- } \\
\text { mation. }\end{array}$ & New Milford red shale. & & Analomink red shale. \\
\hline $\begin{array}{l}\text { Trimmers Rock sand- } \\
\text { stone. }\end{array}$ & $\begin{array}{l}\text { Starrucca shale and sand- } \\
\text { stone Chemung series. }\end{array}$ & & $\begin{array}{l}\text { Trimmers Rock sand- } \\
\text { stone member of Fort } \\
\text { Littleton formation of } \\
\text { Portage group. }\end{array}$ \\
\hline
\end{tabular}

White considered the units above the Chemung to be part of the Catskill formation and provisionally correlated the red beds below the Delaware River flags in Pike and Monroe Counties with red shale near New Milford, Susquehanna County. He considered a thick section of rocks exposed along the Lehigh River south of Packerton to be the Delaware River flags. These are underlain by red and gray beds equivalent to his New Milford red shale and Starrucca sandstone of areas to the northeast. He included the marine beds below this and above the Hamilton with the Chemung series.

Willard assigned White's Delaware River flags and underlying units above the Hamilton along the Lehigh River south of Packerton to the Portage group, including them in his Trimmers Rock sandstone. $\mathrm{He}$ considered the red shale below the Delaware River flags in Pike and Monroe Counties to be a local unit, which he named the Analomink red shale, and he believed that both units are older than the New Milford red shale of Susquehanna County. On Willard's geologic map of northeastern Pennsylvania (1936, 1939), the Delaware River flags and Analomink red shale are shown to pinch out in Monroe County and do not extend to the Lehigh River.

Conceivably, the Walcksville member of the Catskill formation along the Lehigh River is older than the Analomink red shale in Monroe County, and the Analomink is older than the New Milford shale of Susquehanna County, but more detailed mapping in these areas will be required to determine the actual relations.

The Beaverdam Run and Walcksville sandstone members of the Catskill formation are distinct mappable units along the Lehigh River and near Walcksville, but in places about 30 miles to the west, rocks in the equivalent stratigraphic interval form a transition zone between the Trimmers Rock sandstone and the Catskill formation, according to G. H. Wood, Jr., and H. H. Arndt, of the U.S. Geological 
Survey (oral communication, 1960). Wood and Arndt consider the base of the Catskill formation to be the base of the lowest red bed in the transition zone.

\section{TRIMMERS ROCK SANDSTONE}

The Trimmers Rock sandstone, here adopted by the U.S. Geological Survey, includes in the project area the beds between the dark-gray shale at the top of the Middle Devonian Marcellus and Hamilton formations and the basal red beds of the Catskill formation. These rocks were included in the Portage group by Willard (1935) but may not be exact time equivalents of the Portage group at the type locality in New York. A large part of the Trimmers Rock sandstone is exposed in roadcuts along the northeastern extension of the Pennsylvania Turnpike near Walcksville, Carbon County, and along the Lehigh River north of Jamestown, Carbon County. The formation is about 1,300 feet thick near Jamestown and may be equally thick near Walcksville. The lower part is mostly concealed in both areas, and the approximate thickness is based on measurements of the distance between contacts as mapped, with corrections for dip and strike.

About 150 feet of the upper part of the Trimmers Rock sandstone contains plant fossils, and no marine fossils were found in the upper 400 feet of this formation. For purposes of mapping, however, the lowest red bed is used as the base of the overlying Walcksville member of the Catskill formation.

A section of gray sandstone and siltstone about 1,000 feet thick below the red bed at the base of the Walcksville sandstone member of the Catskill is well exposed between highway location marks 391 and 402 along the northeastern extension of the Pennsylvania Turnpike. This section was measured and is described in detail in table 3.

\section{Composition}

The Trimmers Rock sandstone consists of very fine to fine-grained sandstone that contains siltstone and thin shaly partings at intervals throughout the section, and siltstone with thin sandy beds in the lowermost 150 feet. The grain size was determined megascopically by comparison of the rock with standards of sized sand grains. The only rock in the entire section that appeared to be as coarse as medium fine to medium in grain size (about $1 / 8$ to $1 / 4 \mathrm{~mm}$ in diam.) is in the uppermost 40 feet of the section, and no rock coarser than medium grained was noted in the section.

The lowermost 150 feet of the section (table 3) is in a shallow part of the roadcut where the rock is weathered to a brownish-gray and has an irregular to blocky fracture. In the deeper parts of the cut, the fresh rock is various shades of gray and many of the beds are massive. 
TABLE 3.-Measured section of part of the Trimmers Rock sandstone of Late Devonian age exposed in a roadcut along the northeastern extension of the Pennsylvania Turnpike near Walcksville, Carbon County, Pa.

\begin{tabular}{|c|c|c|c|c|c|c|}
\hline \multirow{2}{*}{$\underset{\text { locations }}{\text { Turnpike survey }}$} & \multirow{2}{*}{ Rock type and grain size } & \multirow{2}{*}{ Color } & \multirow{2}{*}{ Fossils } & \multirow{2}{*}{ Remarks } & \multicolumn{2}{|c|}{$\begin{array}{l}\text { Thickness } \\
\text { (in feet) }\end{array}$} \\
\hline & & & & & (Unit) & (Total) \\
\hline $402+7$ to $402+3$ & Very fine grained sandstone and silt- & Greenish gray & & & 4 & 4 \\
\hline $\begin{array}{l}402+3 \text { to } 401+97 \\
401+97 \text { to } 401+93\end{array}$ & $\begin{array}{l}\text { Siltstone- } \\
\text { Fine- to medium-fine-grained sand- }\end{array}$ & Dark gray. & & & 6 & 10 \\
\hline $401+97$ to $401+93$ & $\begin{array}{l}\text { Fine- to medium-fine-grained sand- } \\
\text { stone. }\end{array}$ & Light gray - - & & Massive.... & 4 & 14 \\
\hline $401+93$ to $401+90$ & $\begin{array}{l}\text { Medium-gray sandstone and black } \\
\text { shale. }\end{array}$ & $\begin{array}{c}\text { Greenish gray with black } \\
\text { bands. }\end{array}$ & & Lenslike bed. & 3 & 17 \\
\hline $\begin{array}{l}401+90 \text { to } 401+75 \\
401+75 \text { to } 401+70\end{array}$ & Fine-grained sandstone & Light to greenish gray, rust & & Massive... & $\begin{array}{r}15 \\
5\end{array}$ & $\begin{array}{l}32 \\
37\end{array}$ \\
\hline $401+70$ to $401+40$ & Medium-fine-grained sandstone-..... & Light gray & & Massive black shale chips.....- & 29 & 66 \\
\hline $\begin{array}{l}401+40 \text { to } 401+35 \\
401+35 \text { to } 400+95\end{array}$ & $\begin{array}{l}\text { Very fine grained, silty sandstone..... } \\
\text { Fine-grained sandstone. }\end{array}$ & $\begin{array}{l}\text { Dark to medium gray } \\
\text { Light gray }\end{array}$ & 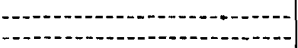 & $\begin{array}{l}\text { Bed pinches out up dip. } \\
\text { Massive.... }\end{array}$ & $\begin{array}{r}5 \\
39\end{array}$ & $\begin{array}{r}71 \\
110\end{array}$ \\
\hline $\begin{array}{l}400+95 \text { to } 400+90 \\
400+90 \text { to } 400+30\end{array}$ & & Light-greenish gray.-.-. & & Massive and lensing beds & 5 & 115 \\
\hline $400+30$ to $400+20$ & Filty, very fine grained sandstone..... & $\begin{array}{l}\text { Lignt and dark gray.... } \\
\text { Gray }\end{array}$ & & Massive and lensing beds....... & $\begin{array}{l}58 \\
10\end{array}$ & $\begin{array}{l}173 \\
183\end{array}$ \\
\hline $\begin{array}{l}400+20 \text { to } 400+15 \\
400+15 \text { to } 400+10\end{array}$ & Fine-grained sandstone & $\begin{array}{l}\text { Greenish gray } \\
\text { Bluish gray }\end{array}$ & -- & Massive. & $\begin{array}{r}5 \\
5\end{array}$ & $\begin{array}{l}188 \\
193\end{array}$ \\
\hline $400+10$ to $399+98$ & Siltstone & Greenish gray & - & - & 12 & 205 \\
\hline $399+95$ to $399+8$ & Fine-grained sandstone............. & Light gray.- & Coaly plant fossils at 399 & --- & $\mathbf{5}$ & 223 \\
\hline $399+80$ to $399+65 \ldots$ & Siltstone and fine-grained sandstone...- & Dark gray.-- & & Blotches or lenses of poorly & 15 & 238 \\
\hline $\begin{array}{l}399+65 \text { to } 399+60 \\
399+60 \text { to } 399+50\end{array}$ & $\begin{array}{l}\text { Fine-grained sandstone } \\
\text { Siltstone }\end{array}$ & Light gray.-............. & & Thinly banded, hard & $\begin{array}{r}5 \\
10\end{array}$ & 243 \\
\hline $399+50$ to $399+24$ & Fine-grained sandstone- & Greenish gray & $(-\cdots+10$ & Massive and banded & 25 & 278 \\
\hline $399+24$ to $398+13 \ldots$ & $\begin{array}{l}\text { Fine to very fine grained silty sand- } \\
\text { stone. }\end{array}$ & Gray to dark gray........ & $-\ldots$ & $\begin{array}{l}\text { Sandstone roll with black shale } \\
\text { surfaces at } 398+45 \text {. }\end{array}$ & 107 & 385 \\
\hline $398+13$ to $397+80$ & $\begin{array}{l}\text { Siltstone and very fine grained sand- } \\
\text { stone }\end{array}$ & $\begin{array}{l}\text { Very dark gray to slate gray } \\
\text { and bluish gray. }\end{array}$ & & (- & 32 & 417 \\
\hline $397+80$ to $397+25$ & Fine- to very fine grained sandstone..- & Gray to bluish gray..... & Brachiopods at $397+70$ & Storm roller with black shale & 53 & 470 \\
\hline $397+25$ to $396+25 \ldots$ & Fine-grained sandstone & Gray .......... & $\begin{array}{l}\text { Several thin cocquinite } \\
\text { layers of brachiopod fos- }\end{array}$ & & 96 & 566 \\
\hline $396+25$ to $395+93$ & Very fine grained sandstone with shaly & Bluish gray ................. & Cocquinite layer.. & Ribbon banding of black shale. & 31 & 597 \\
\hline $395+93$ to $395+45$ & Fine-grained sandstone & Bluish gray to brownish gray & & $\begin{array}{l}\text { Massive and thick bedded, a } \\
\text { few thin banded beds. }\end{array}$ & 47 & 644 \\
\hline
\end{tabular}




\begin{tabular}{|c|c|c|c|c|c|c|}
\hline $5+45$ to $395+20$ & - to very tine grained silty & Dark gray to brownish gray. & & & 24 & 668 \\
\hline $395+20$ to $394+72 \ldots$ & Fine-grained sandstone....- & Dark, bluish, and brownish & & Massive and thick bedded.... & 47 & 715 \\
\hline $394+72$ to $394+39$ & Fine- to very fine grained sandstone & Dark brown to brownish gray. & & Blocky, medium to thin bed- & 32 & 747 \\
\hline $394+39$ to $393+90$ & Fine-grained sandstone with silty & Dark gray to bluish gray with & & & 48 & 795 \\
\hline $393+90$ to $393+50$ & $\begin{array}{l}\text { bands. } \\
\text { Fine- to very fine grained sandstone... }\end{array}$ & $\begin{array}{l}\text { thin brown or black layers. } \\
\text { Slate gray to bluish gray with }\end{array}$ & & Hard, massive, thick bedded. & 39 & 834 \\
\hline $393+50$ to $392+50$ & Very fine grained sandstone..... & Dark gray, with bands of tan & & Blocky & 97 & 931 \\
\hline $\begin{array}{l}392+50 \text { to } 391+5 \\
\text { end of roadcut. }\end{array}$ & $\begin{array}{l}\text { Siltstone with thin shaly and sandy } \\
\text { layers. Massive and blocky } 392+0 \\
\text { to } 392+50\end{array}$ & Olive gray to brownish gray..- & & $\begin{array}{l}\text { Mostly concealed from } 391+5 \\
\text { to } 392+0 \\
\text { Lower part of formation con- } \\
\text { cealed. }\end{array}$ & 141 & 1,072 \\
\hline
\end{tabular}


In the middle of the section some thick beds are bluish gray; other layers are brownish gray and gray banded with black. In the upper part of the section, most of the rock is dull gray with thick greenishgray beds about 250,200 , and 100 feet below the top. In the uppermost 20 feet of the member, there are massive greenish-gray and darkgray beds.

Roll structures such as those described as storm rollers and illustrated by Willard $(1939$, p. 211) occur about 400 feet below the top of the Trimmers Rock sandstone. These will be described in a later section. (See p. 68.)

The basal part of the formation is concealed in the measured section (table 3) but is well exposed at Wild Creek near the reservoir. The rock there is very fine to medium-grained sandstone and siltstone similar to rock interlayered with shale in the upper part of the Marcellus and Hamilton sequence in this area.

The rock of the Trimmers Rock is low-rank graywacke, according to the Krynine classification (Krynine, 1948, table 3). The granular minerals are generally well sorted and the elongate fragments are moderately oriented parallel to the bedding. In most samples the grains are loosely packed because of the abundance of matrix minerals.

Quartz is the most abundant of the granular detrital minerals. The quartz grains range in shape from equant to elongate and are subrounded to angular. Most are angular; some have irregular borders and appear to have been etched or modified in shape by solution. Many of the grains have wavy extinction. No euhedral quartz grains were seen in thin section, but euhedral quartz occurs in fracture fillings. Some grains have hairlike inclusions, others have a pitted appearance that may be due to minute rounded inclusions or cavities. No silica overgrow ths were observed on the quartz grains. Quartzite fragments and grains of chert and aphanitic rock make up a small percentage of the rock. Unaltered twinned feldspar and partly decomposed feldspar with low extinction angles are minor granular minerals.

The matrix minerals are chlorite and illite or fine-grained muscovite in bunches that bend around the granular minerals. These matrix minerals may be partly detrital and partly metamorphic in origin. A few flakes of muscovite and biotite that differ in appearance from the micaceous matrix minerals and may be detrital occur in many of the samples. Limonite in scattered particles and local concentrations stains the weathered rock. A few beds have calcareous cement and micaceous matrix minerals, but most of the rock is not calcareous.

Zircon, tourmaline, leucoxene, magnetite, and ilmenite, and limonite pseudomorphs of pyrite, are accessory minerals. Zircon in rounded 
elongate grains, in angular grains, and in rounded and angular fragments, was seen in a heavy mineral band in one thin section.

Black carbonaceous material occurs in plant fossils and possibly in thin black shaly layers in sandstone.

The abundance of molds of crinoid plates and brachiopods in some 1:hin layers suggests that they may have been concentrated by mechanj.cal as well as ecological means.

Minerals identified in the clay-size fraction of samples of the Trimmers Rock by X-ray spectrometer analysis are quartz, chlorite, jllite, and possibly siderite and dolomite.

\section{Distribution}

The Trimmers Rock sandstone is at the surface along both limbs of the Lehighton anticline in narrow bands that extend from Jamestown and Big Creek at the southern edge of the project area to the rastern edge of the quadrangle. The formation is poorly exposed near Stemlersville and in the southeastern corner of the project area, where the rubble of fossiliferous gray rock from the Trimmers Rock and of the red rock from the overlying Walcksville sandstone member of the Catskill formation have been intermixed in the fields by plowing. Thus, the relations of the marine and nonmarine beds are not clear in some places. Along the southern flank of Indian Hills and south of Pohopoco Creek the Trimmers Rock is more resistant to erosion than rocks of the adjoining Marcellus and Hamilton formations, and it forms high ground, particularly where the beds dip more than about $30^{\circ}$.

\section{CATSKILI FORMATION}

The Catskill formation, of Late Devonian age, is the uppermost Devonian formation in the project area. It is about 7,400 feet thick and consists of about 6,500 \pm feet of red and gray nonmarine clastic sedimentary rock and about 900 feet of gray and olive-gray marine clastic sedimentary rock. The Catskill overlies the Trimmers Rock sandstone and underlies the Pocono formation. A subdivision of the Catskill formation in the Lehighton quadrangle into five members is here proposed: from bottom to top, the Walcksville sandstone member, the Beaverdam Run member, the Damascus redbed member, the Honesdale sandstone member, and the Cherry Ridge redbed member. The names of the upper three members were used by Willard (1936, pl. 2) on his geologic map of northeastern Pennsylvania. The lower two members are newly described. Measured sections of these units are described in table 4. 
TABLE 4.-Measured sections of members of the Catskill formation, of Late Devonian age, in Carbon County, Pa.

\begin{tabular}{l|l|l|l|l}
\hline Rock type and grain size & Color & Remarks & \multicolumn{2}{c|}{$\begin{array}{c}\text { Thickness } \\
\text { (in feet) }\end{array}$} \\
\hline
\end{tabular}

Cherry Ridge redbed member

[Measured along U.S. Route 309 and along the Lehigh Valley Railroad at Mauch Chunk ridge south of Jim Thorpe. All but top and bottom of section measured by tape held approximately perpendicular to bedding. Top in terval concealed, thickness given is approximate. Bottom unit measured by pacing up hill at low angle to strike. The contact with the underlying Honesdale sandstone member is arbitrarily drawn between reddish-gray and gray beds]

\begin{tabular}{|c|c|c|c|c|}
\hline $\begin{array}{l}\text { Coarse and pebbly to very fine } \\
\text { grained sandstone and silt- } \\
\text { stone. }\end{array}$ & $\begin{array}{l}\text { Red, gray, reddish } \\
\text { and greenish gray. }\end{array}$ & $\begin{array}{l}\text { Top of Catskill formation, top } \\
\text { of Cherry Ridge member. } \\
\text { Concealed along U.S. Route } \\
309 \text {, exposed along Lehigh } \\
\text { Valley Railroad on east side } \\
\text { of river. }\end{array}$ & 56 & 56 \\
\hline $\begin{array}{l}\text { Medium to coarse grained sand- } \\
\text { stone. }\end{array}$ & Gray to reddish & $\begin{array}{l}\text { Color grades to reddish gray } \\
\text { near top. }\end{array}$ & 37 & 93 \\
\hline and sil.tstone & $\begin{array}{l}\text { Red, reddish } \mathrm{g} \\
\text { and gray. }\end{array}$ & $\begin{array}{l}\text { Mostly concealed, red silt- } \\
\text { stone on top. }\end{array}$ & 31.5 & 124.5 \\
\hline ined sandstone.....- & Reddish gray & $\begin{array}{l}\text { Massive } \\
\text { Red siltstone on top. }\end{array}$ & $\begin{array}{l}24 \\
25\end{array}$ & $\begin{array}{l}148.5 \\
173.5\end{array}$ \\
\hline sto & Gra & & & \\
\hline ained sand- & Greenish gra & & 12 & 185.5 \\
\hline 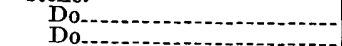 & $\begin{array}{l}\text { Gra } \\
\text { Red }\end{array}$ & Mas & $\begin{array}{r}3 \\
12\end{array}$ & $\begin{array}{l}188.5 \\
200.5\end{array}$ \\
\hline Dinod andutom-1- & 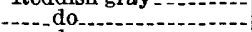 & Fin & & 218.5 \\
\hline & -2 & $\begin{array}{l}\text { Four layers of } \\
\text { chips of red }\end{array}$ & 17.5 & 236 \\
\hline $\begin{array}{l}\text { Coarse- to fine-grained sand- } \\
\text { stone. }\end{array}$ & Gray, greenis & & 11.5 & 247.5 \\
\hline ained and silty sand- & 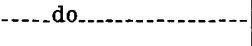 & & 17.5 & 265 \\
\hline ined sandstone.-. & $\begin{array}{l}\text { Reddish } \\
\text { Gray,gr }\end{array}$ & & $\begin{array}{r}16.5 \\
8.5\end{array}$ & $\begin{array}{l}281.5 \\
290\end{array}$ \\
\hline $\begin{array}{l}\text { Coarse-grained sandstone and } \\
\text { siltstone. }\end{array}$ & Red & $\begin{array}{l}\text { Wedging units, quartz-healed } \\
\text { fractures. }\end{array}$ & 19 & 309 \\
\hline & Red & & & \\
\hline medium-grained & Red & $\begin{array}{l}\text { Crossbedded sai } \\
\text { ers tan. }\end{array}$ & 8.5 & \\
\hline Sanc & $\operatorname{Rec}$ & Dis & 55 & 39 \\
\hline Coar & Red & $\begin{array}{l}\text { Distinct beddi } \\
\text { tact on top of } \\
\text { eroded, has w }\end{array}$ & 17 & 410.5 \\
\hline (2) & Red & Thin & 5.5 & 416 \\
\hline ined & Red & Gradational grai & $\begin{array}{r}102.5 \\
6.5\end{array}$ & $\begin{array}{l}559.5 \\
566\end{array}$ \\
\hline ied conglomeratic & Gra & Massive_..- & 14 & 580 \\
\hline $\begin{array}{l}\text { sandstone. } \\
\text { Medium-grained sandstone } \\
\text { and siltstone. }\end{array}$ & $\operatorname{Rec}$ & $\begin{array}{l}\text { Sandstone in Ic } \\
\text { into siltston } \\
\text { then to sand }\end{array}$ & 15.5 & 595.5 \\
\hline Goma & & Mass & & \\
\hline Sand & Gre & hinbedded, shear & 12.5 & \\
\hline $\begin{array}{l}\text { um-grained sand- } \\
\text { pebbly sandstone. }\end{array}$ & & $\begin{array}{l}\text { Thinbedded, wedge of cross- } \\
\text { bedded sandstone with peb- } \\
\text { bly layer at base. }\end{array}$ & 9.5 & 630.5 \\
\hline C & $\mathrm{Re}$ & & & 656.5 \\
\hline & & $\begin{array}{l}\text { Flaggy and block } \\
\text { Massive }\end{array}$ & 5 & \\
\hline & Red. & & & \\
\hline $\begin{array}{l}\text { Coarse-grained and pebbly } \\
\text { sandstone. }\end{array}$ & Reddish g & $\begin{array}{l}\text { Massive to laminated, cross- } \\
\text { bedded, red bed chips in } \\
\text { pebbly layer. }\end{array}$ & 48 & 769 \\
\hline $\begin{array}{l}\text { Fine-grained sandstone and } \\
\text { siltstone. }\end{array}$ & & Grades to siltstone at top....... & 11.5 & 80.5 \\
\hline $\begin{array}{l}\text { Coarse-grained pebbly sand- } \\
\text { stone. }\end{array}$ & Reddish g & Massive, crossbedded . - & 13.5 & 794 \\
\hline $\begin{array}{l}\text { Conglomeratic coarse-grained } \\
\text { sandstone. }\end{array}$ & & Crossbedded at top.. & 30 & 824 \\
\hline $\mathrm{Co}$ & . do & $\begin{array}{l}\text { Massive, with } 0.7 \mathrm{ft} \text { reddish- } \\
\text { gray silty layer on top. }\end{array}$ & 8.5 & 2.5 \\
\hline
\end{tabular}


TABLE 4.-Measured sections of members of the Catskill formation, of Late Devonian age, in Carbon County, Pa.-Continued

\begin{tabular}{|c|c|c|c|c|}
\hline \multirow{2}{*}{ Rock type and grain size } & \multirow{2}{*}{ Color } & \multirow{2}{*}{ Remarks } & \multicolumn{2}{|c|}{$\begin{array}{l}\text { Thickness } \\
\text { (in feet) }\end{array}$} \\
\hline & & & Unit & Total \\
\hline \multicolumn{5}{|c|}{ Cherry Ridge redbed member-Continued } \\
\hline $\begin{array}{l}\text { Silty sandstone } \\
\text { Sandstone. } \\
\text { Medium- to coarse-grained and } \\
\text { congomeratic sandstone, con- } \\
\text { glomerate. } \\
\text { Medium-grained sandstone.... } \\
\text { Medium- to coarse-grained con- } \\
\text { glomeratic sandstone, con- } \\
\text { glomerate. }\end{array}$ & $\begin{array}{l}\text { Greenish gray } \\
\text { Gray, reddish gray. } \\
\text { Reddish gray } \\
\text { Gray._. } \\
\text { Gray, reddish gray... }\end{array}$ & $\begin{array}{l}\text { Thinbedded. } \\
\text { Radioactive rock at top } \\
\text { Pebbles disseminated and in } \\
\text { layers. Silty red zone about } \\
3 \text { ft thick at top. } \\
\text { Radioactive rock. } \\
\text { Sandstone massive to flaggy, } \\
\text { crossbedded; conglomerate } \\
\text { massive, reddish gray. } \\
\text { Base of Cherry Ridge mem- } \\
\text { ber. }\end{array}$ & $\begin{array}{c}4 \\
15 \\
44.5 \\
\\
5 \\
50 \pm\end{array}$ & $\begin{array}{l}836.5 \\
851.5 \\
896 \\
\\
901 \\
950 \pm\end{array}$ \\
\hline
\end{tabular}

Honesdale sandstone member

[Measured along U.S. Route 309 on Mauch Chunk ridge, southeast of Jim Thorpe, Carbon County, Pa. Measured by pacing; corrected for dip and strikel

Fine- to coarse-grained sandstone and silty sandstone.

Fine to coarse and pebbly sandstone.

Medium- to coarse-grained and pebbly sandstone.

Conglomerate.

Siltstone.

Sandstone to siltstone

Sandstone to sultstonestone.

Quartz pebble conglomerate.

coarse-grained pebbly sandstone.

Quartz pebble conglomerate..

Siltstone.

Silty sandstone.

Medium- to coarse-grained pebbly sandstone, conglomerate.

Siltstone..............

Very coarse grained sandstone.

Siltstone. Do._...

Coarse-grained pebbly sandstone, medium- to coarsegrained sandstone.

Very coarse grained pebbly sandstone, medium- to coarse grained sandstone.

Silty sandstone

Medium. to coarse-grained sandstone.

Medium- to coarse-grained sandstone grading to siltstone.

Very coarse grained pebbly sandstone.

Medium- to coarse-grained silty and pebbly sandstone.

Medium- to coarse-grained sandstone.

Siltstone.

Medium-grained sandstone

Medium-grained sandstone; siltstone.

Medium- to coarse-grained pebbly sandstone with shale chips.

\begin{tabular}{|c|c|c|c|}
\hline $\begin{array}{l}\text { Gray, greenish gray, } \\
\text { brownish gray. } \\
\text { Brownish gray........ }\end{array}$ & $\begin{array}{l}\text { Top of Honesdale sandstone } \\
\text { member. Micaceous, flag- } \\
\text { gy to blocky. } \\
\text { Micaceous... }\end{array}$ & 53 & 53 \\
\hline $\begin{array}{l}\text { Gray, brownish gray, } \\
\text { reddish gray. }\end{array}$ & $\begin{array}{l}\text { Micaceous, massive to medi- } \\
\text { um bedded and blocky. }\end{array}$ & 68 & 123 \\
\hline $\begin{array}{l}\text { Light gray } \\
\text { Red }\end{array}$ & Quartzitic. & $\begin{array}{l}10 \\
10\end{array}$ & $\begin{array}{l}133 \\
143\end{array}$ \\
\hline Reddish gray & Grain size finer towards top.- & 14 & 157 \\
\hline $\begin{array}{l}\text { Gray, light-brownish } \\
\text { gray. }\end{array}$ & Micaceous. & 5 & 162 \\
\hline Light-brownish gray . & Banded with dark layers & $\begin{array}{l}14 \\
17\end{array}$ & $\begin{array}{l}176 \\
193\end{array}$ \\
\hline Red do & Massive & $\begin{array}{r}2.5 \\
19.5\end{array}$ & 195.5 \\
\hline Reddish gray & Grad & 10 & 225 \\
\hline $\begin{array}{l}\text { Greenish gray, red- } \\
\text { dish gray. }\end{array}$ & $\begin{array}{l}\text { Shale chips in sandstone, red- } \\
\text { dish gray near top. }\end{array}$ & 58 & 283 \\
\hline Greenish gray... & $\begin{array}{l}\text { Mottled with reddish gray in } \\
\text { top } 10 \mathrm{ft} \text {. }\end{array}$ & 29 & 331 \\
\hline $\begin{array}{l}\text { Red } \\
\text { Greenish gray }\end{array}$ & & 19.5 & $\begin{array}{l}350.5 \\
355.5\end{array}$ \\
\hline $\begin{array}{l}\text { Red } \\
\text { Gray, greenish gray. }\end{array}$ & $\begin{array}{l}\text { olive green, black, red shale } \\
\text { chips and red partings. }\end{array}$ & $\begin{array}{l}10 \\
58\end{array}$ & $\begin{array}{l}365.5 \\
423.5\end{array}$ \\
\hline$\ldots$ do & $\begin{array}{l}\text { Shale chips in pebbly beds, } \\
\text { massive. }\end{array}$ & 67 & 490.5 \\
\hline Slate gray & Micaceous and carbonaceous & .5 & 491 \\
\hline $\begin{array}{l}\text { Greenish gray, light } \\
\text { brownish gray, red- } \\
\text { dish gray. }\end{array}$ & $\begin{array}{l}\text { Thick-bedded, lensing, cross- } \\
\text { bedded. }\end{array}$ & 130 & 621 \\
\hline $\begin{array}{l}\text { Greenish gray, red- } \\
\text { dish gray, red. }\end{array}$ & Lensing and flaggy sandstone. & 19 & 640 \\
\hline Greenish gray ... & Crossbedded. & 14 & 654 \\
\hline Gray, greenish gray & Banded, massive to blocky & 160 & 814 \\
\hline $\begin{array}{l}\text { Gray, light-brownish } \\
\text { and reddish gray. }\end{array}$ & Silty zones and banded beds.- & 91 & 905 \\
\hline $\begin{array}{l}\text { Greenish } \\
\text { Reddish }\end{array}$ & & $\begin{array}{r}3 \\
74\end{array}$ & $\begin{array}{l}908 \\
982\end{array}$ \\
\hline $\begin{array}{l}\text { Gray, light-brownish } \\
\text { gray. } \\
\text { Light-brownish gray. }\end{array}$ & $\begin{array}{l}\text { Sandstone micaceous, thin red } \\
\text { siltstone layers. } \\
\text { Massive, crossbedded }\end{array}$ & $\begin{array}{r}14 \\
124\end{array}$ & $\begin{array}{r}996 \\
1,120\end{array}$ \\
\hline Lignt-Dro & Massive, crossiedued. & 124 & \\
\hline
\end{tabular}


TABLE 4.-Measured sections of members of the Catskill formation, of Late Devonian age, in Carbon County, Pa.-Continued

\begin{tabular}{|c|c|c|c|c|}
\hline \multirow{2}{*}{ Rock type and grain size } & \multirow{2}{*}{ Color } & \multirow{2}{*}{ Remarks } & \multicolumn{2}{|c|}{$\begin{array}{l}\text { Thickness } \\
\text { (in feet) }\end{array}$} \\
\hline & & & Unit & Total \\
\hline \multicolumn{5}{|c|}{ Honesdale sandstone member-Continued } \\
\hline Siltstone............ & Red, greenish gray.-.- & Red grades to greenish gray & 37 & 1,157 \\
\hline Medium- to coarse-grained & Light-brownish gray.. & Mostly concealed..... & 206 & 1,363 \\
\hline Siltstone_... & Red, greenish gray. & Interbedded red and greenish & 68 & 1,431 \\
\hline Medium-grained sandstone....-- & $\begin{array}{l}\text { Gray, light-brownish } \\
\text { gray }\end{array}$ & $\begin{array}{l}\text { Massive, crossbedded, band- } \\
\text { ed. Finely crossbedded }\end{array}$ & 163 & 1,594 \\
\hline Siltstone....... & Whitish to light-blu- & Numerous fragmental plant & 1 & 1,595 \\
\hline Medium-grained sandstone & Light-brownish gray.. & Banded, finely crossbedded...- & 81 & 1,676 \\
\hline $\begin{array}{l}\text { Fine-grained sandstone and } \\
\text { siltstone. }\end{array}$ & & & 6 & 1,682 \\
\hline $\begin{array}{l}\text { Fine-grained sandstone. (Base } \\
\text { of Honesdale member) }\end{array}$ & Greenish gray & & 43 & 1,725 \\
\hline
\end{tabular}

\section{Damascus redbed member}

[Measured along U.S. Route 309 and Lehigh Valley Railroad near Packerton. Measured by pacing; thickness corrected for dip and strike]

Fine-to medium-grained sandstone

Very fine grained sandstone and siltstone.

Medium-grained sandstone..... Siltstone ....................... Medium-grained sandstone.

Siltstone and sandstone.

Sandstone and siltstone

Do..

Sandstone, siltstone, and shale Sandstone and siltstone float. Sandstone and siltstone

Shale, siltstone, and sandstone Sandstone, siltstone, and shale. Siltstone, sandstone, and shale.

Sandstone, siltstone, and shale.

Siltstone and sandstone

Sandstone, siltstone, and shale. Fine-to medium-grained sandstone and siltstone with shaly partings.

Fine-grained sandstone

Fine-grained sandstone and siltstone

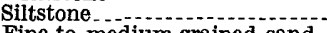

Fine-to medium-grained sandstone.

Siltstone and sandstone

Siltstone

Siltstone and silty sandstone

Siltstone and sandstone

\begin{tabular}{|c|c|c|c|}
\hline Reddish gray, gray. & $\begin{array}{l}\text { Top of section about } 200 \mathrm{ft} \\
\text { south of bend in old U.S. } \\
\text { Route } 309 \text { and junction of } \\
\text { dirt road with Route } 309 \\
\text { north of Packerton. }\end{array}$ & 275 & 275 \\
\hline Red...... & 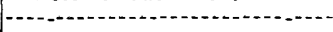 & 15 & 290 \\
\hline Gre & & 60 & 350 \\
\hline Red, reddish gray & & & \\
\hline $\begin{array}{l}\text { Reddish and brown- } \\
\text { nish gray, red. }\end{array}$ & A few thin red beds & 50 & 415 \\
\hline Red... & A few thin olive-gray silty and & 90 & 505 \\
\hline $\begin{array}{l}\text { Red, reddish and } \\
\text { greenish gray. }\end{array}$ & san & 105 & 610 \\
\hline $\begin{array}{l}\text { Reddish } \\
\text { Red, gra }\end{array}$ & & 125 & 735 \\
\hline Red, gray & Hollow, mostly conceale & $\begin{array}{r}240 \\
75\end{array}$ & 1,055 \\
\hline Red. & & 265 & 1,320 \\
\hline $\begin{array}{l}\text { do-.- } \\
\text { do--. }\end{array}$ & Mostly concealed in hollow... & $\begin{array}{r}45 \\
160\end{array}$ & $\begin{array}{l}1,365 \\
1,525\end{array}$ \\
\hline do & $\begin{array}{l}\text { Section along Lehigh Valley } \\
\text { Railroad east of Route } 309 \text {. }\end{array}$ & 405 & 1,930 \\
\hline .....do_. & $\begin{array}{l}\text { School stairway to junction of } \\
\text { lane with U.S. Route } 309 \\
\text { north of school. }\end{array}$ & 500 & 2,430 \\
\hline ............ & $\begin{array}{l}\text { To stairway of Packerton } \\
\text { school at Route } 309\end{array}$ & 120 & 2,550 \\
\hline $\begin{array}{l}\text { Red, gray-- } \\
\text { Red, greenish gray... }\end{array}$ & 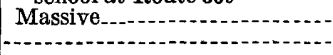 & $\begin{array}{r}110 \\
60\end{array}$ & $\begin{array}{l}2,660 \\
2,720\end{array}$ \\
\hline Gray & Lensing bed............. & $\begin{array}{l}10 \\
12\end{array}$ & $\begin{array}{l}2,730 \\
2,742\end{array}$ \\
\hline Gray, red................. & Hackly fracture... & $\begin{array}{l}7 \\
5\end{array}$ & $\begin{array}{l}2,749 \\
2,754\end{array}$ \\
\hline Gray & 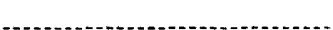 & & \\
\hline Gree & & & 2,797 \\
\hline Red do. & $\begin{array}{l}\text { Mostly concealed along Bea- } \\
\text { verdam Run. }\end{array}$ & $\sim 70$ & $3,040 \pm$ \\
\hline
\end{tabular}


TABLE 4.-Measured sections of members of the Catskill formation, of Late Devonian age, in Carbon County, Pa.

\begin{tabular}{|c|c|c|c|c|c|c|}
\hline \multirow{2}{*}{$\begin{array}{l}\text { Turnpike survey } \\
\text { locations }\end{array}$} & \multirow{2}{*}{ Rock type and grain size } & \multirow{2}{*}{ Color } & \multirow{2}{*}{ Fossils } & \multirow{2}{*}{ Remarks } & \multicolumn{2}{|c|}{$\begin{array}{l}\text { Thickness } \\
\text { (in feet) }\end{array}$} \\
\hline & & & & & (Unit) & (Total \\
\hline
\end{tabular}

\section{Beaverdam Run member}

[Measured along northeastern extension of Pennsylvania Turnpike near Walcksville]

\begin{tabular}{|c|c|c|c|c|c|c|}
\hline $415+45$ to $413+86$ & Very fine grained silty sandstone.... & Brownish gray & tem fossils in & ealed. & 152 & 152 \\
\hline $413+86$ to $413+74$ & Siltstone and fine-grained sandstone... & Gray & part. & $\begin{array}{l}\text { Spheroidal structures. } \\
\text { Spheroidal structures in top }\end{array}$ & 12 & 164 \\
\hline $413+74$ to $413+59$ & Siltstone with thin sandstone on top.-- & Greenish and brownish gra & Crinoid stem & "Pillow structures" on & 14 & 178 \\
\hline $\begin{array}{l}413+59 \text { to } 413+47 \ldots \\
413+47 \text { to } 413+45\end{array}$ & $\begin{array}{l}\text { Fine-grained sandstone...... } \\
\text { Siltstone. }\end{array}$ & $\begin{array}{l}\text { Light brown...- } \\
\text { Khaki brown.-. }\end{array}$ & $\begin{array}{l}\text { brachiopods. } \\
\text { Crinoid stem plates }\end{array}$ & Shear zone with q & 11 & 189 \\
\hline $\begin{array}{l}413+45 \text { to } 413+41 \\
413+41 \text { to } 412+63\end{array}$ & $\begin{array}{l}\text { Very fine grained sandstone } \\
\text { Fine-grained sandstone and siltstone.. }\end{array}$ & $\begin{array}{l}\text { Greenish gray.- } \\
\text { Brownish gray.- }\end{array}$ & $\begin{array}{l}\text { Crinoid stem plates and } \\
\text { calcareous crinoid plate } \\
\text { zone at } 413+2 \text {. }\end{array}$ & $\begin{array}{l}\text { crusted slickensides. } \\
\text { Spheroidal weathering } \\
\text { Spheroidal zone } 413+14 \text { to } 26 \\
\text { "pillow structure" at } 413+26 \text {. }\end{array}$ & $\begin{array}{r}4 \\
74\end{array}$ & $\begin{array}{l}195 \\
269\end{array}$ \\
\hline $\begin{array}{l}412+63 \text { to } 412+58 \\
412+58 \text { to } 412+56\end{array}$ & Fine-grained sandstone & Reddish gray -.-- & - & Hard, thick-bedded. & 5 & $\begin{array}{l}274 \\
276\end{array}$ \\
\hline $412+56$ to $412+48$ & Fine-grained sandstone and siltstone.- & Brownish gray and gray... & $\cdots--$ & Hard, massive. & & 284 \\
\hline $\begin{array}{l}412+48 \text { to } 412+47 \\
412+47 \text { to } 412+30\end{array}$ & Fine-grained sandstone-1o & $\begin{array}{l}\text { Gray } \\
\text { Light-brownish gray }\end{array}$ & Crinoid stem plates in up- & $\begin{array}{l}\text { Hard, cross-bedded. } \\
\text { Weak, blocky }\end{array}$ & $\begin{array}{r}1 \\
17\end{array}$ & $\begin{array}{l}285 \\
302\end{array}$ \\
\hline $412+30$ to $412+26$ & Siltstone and shale & Pale $\tan$ & per & & 4 & 306 \\
\hline 412 & Fine-grained sandstone................ & $\begin{array}{l}\text { Grayish tan and light-brown- } \\
\text { ish gray. }\end{array}$ & & $\begin{array}{l}\text { Spheroidal weathering at } 412 \\
+13 \text {. }\end{array}$ & 33 & 339 \\
\hline $\begin{array}{l}411+91 \text { to } 411+82 \\
411+82 \text { to } 411+51\end{array}$ & $\begin{array}{l}\text { Siltstone } \\
\text { Fine-grained sandstone }\end{array}$ & $\begin{array}{l}\text { Olive tan.. } \\
\text { Tan }\end{array}$ & 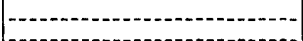 & Thin-bedded & 9 & $\begin{array}{l}348 \\
377\end{array}$ \\
\hline $411+51$ to $411+47 \ldots$ & (n) & Olive $\tan$ & & & 4 & 381 \\
\hline 411 & Fine-grained sandstone.... & Light-brownish gray. & Crinoid stem plate layer & & 45 & 426 \\
\hline $411+0$ to $409+25$ & $\begin{array}{l}\text { Medium- to very fine-grained sand- } \\
\text { stone and siltstone. }\end{array}$ & Brownish gray & & Bedrock mostly concealed..... & 166 & 596 \\
\hline
\end{tabular}




\begin{tabular}{c|c|}
\hline $\begin{array}{c}\text { Turnpike survey } \\
\text { locations }\end{array}$ & Rock type and grain size \\
\hline
\end{tabular}

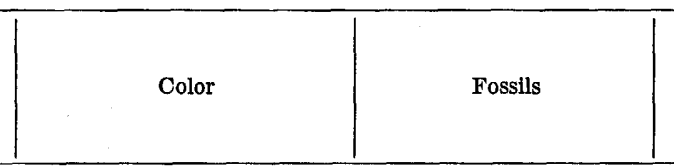

\begin{tabular}{|l|l|l|l} 
Remarks & $\begin{array}{c}\text { Thickness } \\
\text { (in feet) }\end{array}$ \\
\hline (Unit) & (Total) \\
\hline
\end{tabular}

Walcksville sandstone member

[Measured along northeast extension of Pennsylvania Turnpike near Walcksville. This interval is thickened by about 50 feet due to drag folding]

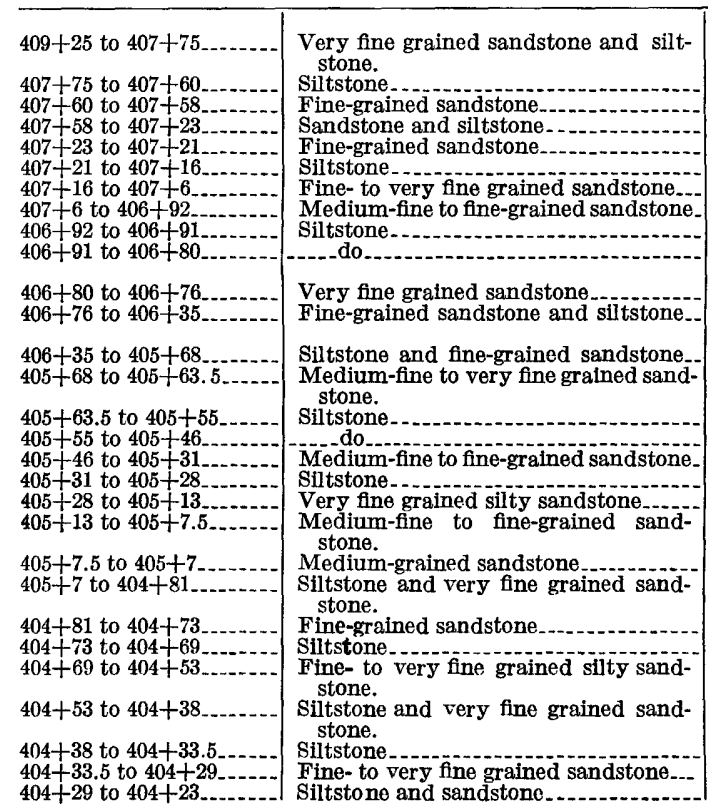

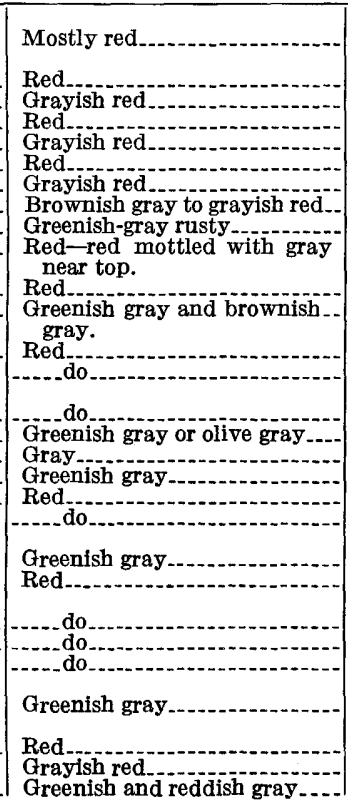

$\left|\begin{array}{|l|}\hline \\ \hline\end{array}\right|$

\begin{tabular}{|c|}
\hline $\begin{array}{l}\text { Mostly concealed. } \\
\text { Poorly exposed } \\
\text { Massive exposed... } \\
\text { Poorly } \\
\text { Massive_.... } \\
\text { Poorly exposed }\end{array}$ \\
\hline Massive \\
\hline $\begin{array}{l}\text { Poorly exposed. } \\
\text { Hard. } \\
\text { Poorly exposed. }\end{array}$ \\
\hline $\begin{array}{l}\text { Drag fold } \\
\text { Becomes finer grained toward } \\
\text { top. } \\
\text { Green parting on top. }\end{array}$ \\
\hline Massive-_. \\
\hline $\begin{array}{l}\text { Massive, finer grained toward } \\
\text { top. }\end{array}$ \\
\hline 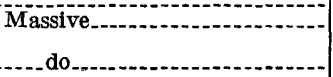 \\
\hline Massive................ \\
\hline Alternate beds $2+\mathrm{ft}$ thick. \\
\hline $\begin{array}{l}\text { Hard , massive } \\
\text { Sandstone in b }\end{array}$ \\
\hline
\end{tabular}

148

\begin{tabular}{r|r}
148 & 148 \\
15 & 163 \\
2 & 165 \\
34 & 199 \\
2 & 201 \\
5 & 206 \\
10 & 216 \\
14 & 230 \\
1 & 231 \\
11 & 242 \\
4 & 246 \\
40 & 286 \\
67 & 353 \\
4 & 357 \\
8 & 365 \\
9 & 374 \\
15 & 389 \\
3 & 392 \\
15 & 407 \\
5 & 412 \\
1 & 413 \\
26 & 439 \\
8 & 447 \\
4 & 451 \\
16 & 467 \\
15 & 482 \\
4 & 486 \\
4 & 490 \\
6 & 496
\end{tabular}


$404+23$ to $404+17.5$-.-.-- Medium-fine-grained sandstone with $404+17.5$ to $404+16.5$ $404+16.5$ to $404+1$

$404+1$ to $403+91$

$403+91$ to $403+89$ $403+89$ to $403+73$

$403+73$ to $403+70$ 403+70 to $403+70$ $403+64$ to $403+36$

$403+36$ to $403+34$ $403+34$ to $403+21$

$403+16$ to $403+14$ $403+14$ to $403+5$

$403+5$ to $403+0$ $03+0$ to $402+90$ $402+90$ to $402+82$ $402+82$ to $402+72$ $402+72$ to $402+67$. $402+67$ to $402+63$ $402+63$ to $402+35$ $402+35$ to $402+29$ $402+29$ to $402+25.5$ $402+25.5$ to $402+16$ $402+16$ to $402+9$

$402+9$ to $402+7$ siltstone layers near top.

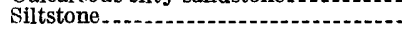

Siltstone and very fine grained sandstone.

Siltstone; very fine grained sandstone

Siltstone and very fine grained sandstone.

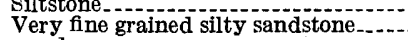
siltstone with a few feet of very fine grained sandstone near top.

grained sandstone near
Fine-grained sandstone.

Siltstone and very fine grained sand-

stone.
Very fine grained silty sandstone

Fine to very fine grained silty sandstone.

Medium-fine-grained sandstone

Medium- to medium-fine-grained sandstone.

Siltstone and very fine grained sandFine-grained sandstone grading to siltstone.

Very fine grained sandstone and siltstone.

Fine-grained sandstone

Medium-fine-grained sandstone.

Siltstone and very fine grained sandvert fine.

stone grained sandstone and silt stone.

Siltstone..

Very fine grained sandstone
Gray

Brownish gray

ray with brown-

sh-gray bands and blotches.

Greenish gray

Red, with green band and mottled.

Red mottled with green.

Greenish gray .....................

Red

Reddish gray.

Light gray to greenish gray Light gray -

Greenish gray

Red.

Reddish gray

Gray

Greenish gray

Red.

.....do.

Red mottled with gray

Gray..

Greenish gray

Red with green bands and rusty-brown mottling.

Red mottled with green-

brown rusty zone at base.

Greenish-gray mottled with

red at base.
Hard, massive.

Weathers rusty

parse concretions about 1 in. in diam.

\begin{tabular}{|r|r|r} 
& 10 & 527 \\
2 & 529
\end{tabular}

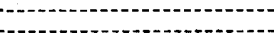

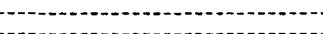

-

Nodules about 1 in. in diam.-.

Massive

do.

Massive.

-....do...

Quartz encrusted joints with fractures.

Massive

Massive

do. 
Between Jamestown and Jim Thorpe, Carbon County, Pa., the Catskill formation is exposed in cliffs and cuts along U.S. Route 309 and the rights-of-way of the Central Railroad of New Jersey and the Lehigh Valley Railroad, which follow the gorge of the Lehigh River through one of the thickest sections of continental Upper Devonian beds in Pennsylvania (Willard, 1939, fig. 40). The beds are steeply dipping, from about $70^{\circ} \mathrm{NW}$. to vertical. There are local drag folds and minor faults with a few feet of displacement in the lower part of the Catskill.

The linear distance from the base of the Catskill between Jamestown and Beaverdam Run to the top of the Catskill as mapped on Bear Mountain is about 7,800 feet along a line perpendicular to the regional strike of $\mathrm{N} .67^{\circ} \mathrm{E}$. The dip of the beds probably averages about $76^{\circ}$. This would indicate a thickness of almost 7,600 feet between the contacts. A correction of about 200 feet for excessive thickening due to drag folding would leave a thickness of about 7,400 feet.

The members of the Catskill have gross features which are distinctive, but they include rocks similar to those in adjoining beds. Boundaries between the members must be selected arbitrarily, and the delineation of contacts over large areas would probably vary somewhat according to the interpretations of different individuals. The members of the Catskill formation in the project area are described as follows and correlated where possible with descriptions by previous workers.

\section{WALCKSVILLE SANDSTONE MEMBER}

The basal nonmarine member of the Catskill formation in the Lehighton quadrangle is here named the Walcksville sandstone member. The type section of the member (table 4) is exposed in a roadcut between highway survey location marks 402 and 410 near Walcksville, Carbon County, Pa., where the northeastern extension of the Pennsylvania Turnpike cuts through the ridge called Indian Hills. The beds are overturned and now trend about N. $67^{\circ}$ E. and dip $83^{\circ} \mathrm{SE}$. The thickness of the section, corrected for dip and strike and almost 50 feet of thickening by drag folding, is about 660 feet. The upper part of the section is mostly concealed, but information that was obtained during highway excavation work permitted determination of the approximate location of the top of the unit. The top and bottom of the member are placed, respectively, at the top of the uppermost red bed and at the bottom of the lowermost red bed in this section.

Another well-exposed section of the Walcksville member was measured, by pacing, along the tracks of the Central Railroad of New Jersey on the west side of the Lehigh River between Jamestown and Packerton. The lower 50 feet of the section is partly concealed, but the approximate location of the base of a poorly-exposed red bed has 
been taken as the base of the member. No lower red bed was seen in an exposure of the lower part of the formation along U.S. Route 309 north of Jamestown. The length of the Jamestown section, corrected for dip and strike, is almost 700 feet. Thus, the two measured sections of steeply dipping beds in locations that are about $3 \frac{1}{2}$ miles apart along strike are in close agreement.

Marine fossils have not been found in this member at either the Walcksville or Jamestown localities. At the Walcksville locality, marine fossils occur in nonred beds about 400 feet stratigraphically below and about 250 feet stratigraphically above the Walcksville member.

\section{Composition}

The Walcksville member consists of red and gray very fine to medium-grained sandstone and siltstone with some thin shaly partings. In most natural exposures and in shallow excavations the gray rock is weathered to brownish-gray.

Red beds make up about 50 to 55 percent of the section at Walcksville. There are a few red beds less than 10 feet thick and several less than 30 feet thick in the lower part of the section. Some of the red beds in the middle and upper part of the section at Walcksville and at Jamestown are as much as 70 feet thick. At Jamestown a few thin red beds, which are less than 15 feet thick, occur in the top 60 feet of the member.

The rock is low-rank graywacke that consists of about 50 to 75 percent granular material and about 25 to 50 percent micaceous and clayey material. Only a few samples were studied petrographically. In these the granular particles are equant to elongate and angular and irregular in outline. Quartz, chert, and rock fragments are the major granular particles. Unaltered and partly sericitized albite-twinned feldspar is a minor component, and dark opaque minerals, zircon, and tourmaline are accessory minerals. Illite and chlorite are abundant micaceous matrix minerals, and biotite occurs in minor amounts. Limonite in small particles stains the rock.

\section{Distribution}

The Walcksville sandstone member crops out in the southern part of the project area along both limbs of the Lehighton anticline and in the syncline near Jonesville (pl. 1). In general, the rocks are poorly exposed, and the outcrop area is difficult to delimit. The Walcksville member extends under the northern part of the Lehighton quadrangle, but no information about its subsurface character is available.

BEAVERDAM RUN MEMBER

A section of gray and olive-tan beds of sandstone and siltstone that overlies the Walcksville sandstone member and underlies the Damas- 
cus red bed member is here named the Beaverdam Run member of the Catskill formation for rocks exposed along U.S. Route 309 on the west side of the Lehigh River just south of Beaverdam Run. A part of the Beaverdam Run member is exposed in a roadcut along the northeastern extension of the Pennsylvania Turnpike between highway survey location marks 409 and 416 near Walcksville. The uppermost and lowermost beds in this member are poorly exposed or partly concealed at both localities. The contacts can be located satisfactorily near Beaverdam Run, but the section there is thickened by drag folding. In the roadcut near Walcksville the upper contact is concealed, but it is exposed on the north slope of Indian Hills, where the beds are overturned and dip about $75^{\circ}$ to the southeast.

The exposed section of the Beaverdam Run member in the Walcksville area, described in table 4 , is about 600 feet thick, but similar rock was found in test drilling for highway construction purposes in the concealed interval a few hundred feet to the north of the roadcut. The Beaverdam Run member may be as much as 900 feet thick in the Walcksville area, and it is between 800 and 900 feet thick along the Lehigh River.

Thin beds of crinoid stem plate molds occur at intervals in the major part of the section but are more abundant in the upper half. Brachiopod fossils are rare in these beds. Spheroidal masses or storm rollers are abundant in the upper half of the section at Walcksville and in the Jamestown-Beaverdam Run area.

\section{Composition}

The Beaverdam Run member consists of gray or greenish-gray very fine grained to medium-fine silty sandstone and siltstone that weathers to brownish gray or olive tan. Most of the beds are fine-grained silty sandstone. The rock is low-rank graywacke and is very similar to the Trimmers Rock sandstone. The reader is referred to petrographic descriptions of these rocks on pages 15-19.

\section{Distribution}

The Beaverdam Run member is at the surface in a narrow zone about 1,000 to 3,000 feet wide along the north limb of the Lehighton anticline. Like the Walcksville sandstone member, it extends under the northern part of the project area, but its subsurface characteristics there are unknown.

\section{DAMASCUS REDBED MEMBER (WILLARD, 1939)}

Between Beaverdam Run and the north side of the village of Packerton, a section about 3,100 feet thick of red beds with some interlayered gray beds has been included in the Damascus by Willard (1939, p. 291292). 
The base of the Damascus, as described here, is at Beaverdam Run and the top is located arbitrarily by the authors at a place about 200 feet south of the hollow near the top of the hill north of Packerton on U.S. Route 309 . This corresponds with the top of a predominantly red section exposed on the east side of the Lehigh River. The overlying gray beds of the Honesdale sandstone member are interlayered with red beds.

\section{Composition}

The lower part of the Damascus redbed member, about 2,000 feet thick, consists of red very fine to medium-coarse-grained sandstone, siltstone, and shale interlayered with gray and greenish-gray sandstone, siltstone, and shale. The upper part, a little more than 1,000 feet thick, consist of red and gray sandstone, siltstone, and shale, but contains a large percentage of sandstone. The gray beds are mostly sandy and are more coarse grained than the red beds.

Although most of the beds are red, gray, or greenish gray, a few calcareous beds are weathered to a dull brown, and some are light-olive gray to buff. The layering ranges from thin shaly partings and thinbedded siltstone and sandstone to thick and massive beds that exhibit little or no noticeable layering except at their contacts with adjoining beds. The clastic granular minerals are relatively well sorted in some layers, but silty sandstone and sandy siltstone are common. There is gradational bedding in some layers in the upper part of the section.

The sandstone and siltstone of the Damascus are low-rank graywacke, and the shale is chloritic and sericitic. Thin sections of sandstone and siltstone were studied. In them, quartz is the most abundant of the granular detrital minerals. It occurs in equant to elongate grains that range from well rounded to angular in shape, and subangular outlines are common. In some beds, the granular minerals have silica overgrowths.

Quartzitic rock fragments and chert are the next most abundant clastic grains and are similar to quartz in habit. They constitute about 12 to 33 percent of the sandstone.

Unaltered twinned feldspar grains, which consist of othoclase, microcline, and albite-twinned plagioclase with low extinction angles, make up less than 1 percent of the rock, but partially decomposed or altered feldspar makes up about 6 percent of some of the red sandstone. Altered feldspar grains and almost completely sericitized grains that probably were feldspar make up about 17 percent of one sample of a red sandstone. Feldspar is much less abundant in the gray beds than in the red. It is an accessory mineral that makes up less than 1 percent of some of the gray rocks, but composes as much as about 5 percent of others. 
Illite, or sericite, is the most abundant matrix mineral. It makes up about 7 percent of some of the gray sandstone, but composes as much as 36 percent and possibly more of the siltstone and shale. The illite is in shreds or bundles that are commonly bent around clastic grains, and in some rocks the elongate bundles are oriented roughly parallel to bedding. If the illite, or sericite, was formed in site by diagenesis or by metamorphism of the decomposition products of feldspar grains, then some of the sediments of the Damascus were arkosic.

Chlorite composes about 1 to 6 percent of the rock. A diagenetic or metamorphic origin of the chlorite is indicated by the patches of well-oriented chlorite flakes that surround the detrital grains. However, some of the chlorite is probably detrital.

Clay-size particles of red iron oxides are very abundant in the red beds, and brown iron oxide in lesser amounts is present in the gray rocks.

Heavy accessory minerals include ilmenite, magnetite, leucoxene, apatite, unidentified green silicates, sphene, tourmaline, and zircon. Ilmenite and magnetite, the most abundant of these, make up a few percent of some rocks that contain heavy mineral layers. The other accessory minerals are much less abundant.

Minerals identified by X-ray spectrometer analysis of clay-size separates include quartz, illite, chlorite, $\mathrm{Fe}_{2} \mathrm{O}_{3}$, and possibly calcite, dolomite, and siderite.

\section{Distribution}

The outcrop area of the Damascus redbed member is in the lowland south of the escarpment of the Pocono Plateau and extends along the south side of Mauch Chunk Ridge, where, because of the steep dips, the member has not been eroded as low as the formations to the south. At the foot of Call Mountain (pl. 1), the Damascus lies almost flat and has been exposed in excavations at the site of the new reservoir. In most places, however, the Damascus is weathered and bedrock is covered by soil or talus. The rock is relatively weak in comparison to that of the other formations, but its position between the resistant Honesdale member and relatively resistant Beaverdam Run member has prevented it from being eroded as deeply as the Marcellus and Hamilton formations.

HONESDALE SANDSTONE MEMBER (WHITE, 1882)

The Honesdale sandstone member overlies the Damascus redbed member and underlies the Cherry Ridge member of the Catskill. The Honesdale, as defined here, includes a section of gray sandstone beds totaling about 1,700 feet thick, with some interbedded red and reddish-gray beds (table 4 ). The Honesdale was described by White 
(1882, p. 97-98) as being 987 feet thick along the Lehigh River near Packerton and containing about 150 feet of red shale. The change is gradational upward from a series of red beds that contain lesser amounts of gray beds in the upper Damascus, to a series of gray beds with a few interlayered red beds in the lower part of the Honesdale sandstone member. In addition, the rocks of the Honesdale are coarser grained than those of the Damascus and include some conglomeratic or pebbly layers.

\section{Composition}

The lower few hundred feet of the Honesdale sandstone member consists of medium- to coarse-grained gray sandstone, some interbedded red sandstone and siltstone, and a few zones of reddish-gray sandstone. Some of the gray beds are pebbly and have delicate traces of crossbedding. Near the middle of the member are two beds of red siltstone, 35 and 20 feet thick, respectively, separated by about 30 feet of massive very coarse-grained greenish-gray sandstone that grades in color and grain size to reddish gray and silty at the top.

Above the upper red bed, the upper half of the Honesdale sandstone member is almost entirely gray sandstone but contains a few layers of conglomerate and some thin beds of greenish-gray siltstone. Crossbedding is common. There is some reddish-gray sandstone, which shows gradational changes in the degree of redness, in a section 50 to 100 feet thick near the top of the Honesdale. The distinctly red or reddish-gray beds that overlie this sandstone are assigned to the Cherry Ridge member.

Most of the rock in the Honesdale member is low-rank graywacke sandstone, but some beds are impure quartzitic sandstone. Quartz is the most abundant of the granular detrital minerals, making up 30 to 50 percent of most of the samples that were examined petrographically. The quartz grains are mostly subangular to subrounded and irregular in outline, but angular and well-rounded quartz grains occur in some beds. Quartz or quartzite pebbles are generally well rounded. Needlelike inclusions and lines of dustlike specks in quartz grains are common. There are silica overgrowths on quartz in a few of the samples.

The rock fragments consist of quartzite, phyllite, and chert, and range from about 8 percent to about 66 percent of the rock. They have about the same habit as the quartz grains. Quartzite makes up the bulk of the rock fragments. Chert composes generally 4 to 5 percent of the rock.

Unaltered twinned feldspar was not identified in most samples of the Honesdale. Sand-size grains of a mineral that probably is seri- 
citized feldspar, and only small amounts of unaltered feldspar that still has indications of albite twinning, were noted in thin sections.

The granular components of the Honesdale are, in general, poorly sorted, but sorting is more pronounced in the samples that are composed of subrounded to rounded grains, heavy-mineral layers, or welldeveloped bedding. The micaceous and clayey matrix minerals bond most of the rock, but there is silica cement in a few beds. Several thin beds have a calcareous cement, and small amounts of calcite cement occur in sandstone near the top of the Honesdale.

The matrix minerals are sericite, chlorite, biotite, and muscovite. Sericite is the most abundant of these; it makes up about 6 to 26 percent of the rock. Some of the sericite is in patches that resemble altered feldspar grains, but the bulk of it is in bundles or matted fibers that are interstitial to and bent by the granular minerals. Elongate bundles of sericite in some samples are alined parallel to directions of incipient cleavage. Some of the sericite is probably diagenetic or metamorphic, but some is of detrital origin.

Chlorite or a greenish hydromica forms about 1 to 12 percent of the rock, as vermicular aggregates, booklike patches, and irregular aggregates. Some individual flakes of chlorite and some clay-size chlorite may be of detrital origin, but the vermicular chlorite and some of the booklike patches may be diagenetic or metamorphic.

Biotite, in individual flakes and brown bundles, makes up a few percent of the rock in several samples, about16 percent in one sample, and is not identified in others. Some of the biotite is in flakes that appear to be detrital, but some may be diagenetic or metamorphic.

Muscovite makes up about 5 percent of one sample, but is only an accessory mineral in most of the rock. Other accessory minerals are feldspar, tourmaline, zircon, apatite, small amounts of black opaque minerals, and earthy iron oxides.

\section{Distribution}

The outcrop area of the Honesdale is along the southern escarpment of the Pocono Plateau; it includes Call Mountain and the south flank of Bear Mountain and Mauch Chunk Ridge. The Honesdale is much more resistant to erosion than is the Damascus. Southeast of Jim Thorpe, the Lehigh River is deflected by the Honesdale and flows in a gorge cut in the overlying red beds of the Cherry Ridge for almost a mile before it turns and cuts through the Honesdale.

Although the Honesdale is resistant to weathering and erosion and forms upland areas with little soil covering, the attitude of the beds is difficult to measure along the escarpment of the plateau. The Honesdale weathers to light-gray and tan irregular blocky talus, and the resistant rock debris on slopes conceals the outcrop of weathered beds. The base of the Honesdale is marked by a change in slope, but 
the contact is generally concealed by sandstone debris. In a few of the deep stream valleys, such as Hell Creek, Pine Creek, and Berry Run, the dip of the beds can be measured, but even in these places the amount of talus covering is appreciable. On Pohopoco Mountain along Engler Run and along the upper part of Little Creek, north of Jonas, only a few outcrops afford satisfactory exposures for measuring the attitude of bedrock.

The Honesdale resembles the sandstone of the Pocono formation and was mistaken for it in the Pocono Plateau area by early workers.

CHERRY RIDGE REDBED MEMBER (WILLARD, 1939)

The Cherry Ridge redbed member (Willard, 1939, p. 284), as here described, is about 950 feet thick and is the uppermost member of the Catskill formation in the mapped area (pl. 1). Its base is set at the bottom of the lowermost distinctly red or reddish-gray bed that overlies the thick section of gray beds of the Honesdale. Its top is at the top of the uppermost red bed, which lies below the thick section of gray sandstone and conglomerate of the Pocono formation. A mottled red and greenish-gray bed, predominantly gray, occurs in the lower part of the Pocono.

The type section of the Cherry Ridge redbed member in the mapped area (table 4) is exposed along U.S. Route 309 and the right-of-way of the Central Railroad of New Jersey south of Jim Thorpe, Carbon County. The base of the unit is about 0.4 mile south of the county courthouse along the highway and the top of the formation is exposed on the east side of the Lehigh River at the foot of Bear Mountain. The beds strike about $\mathrm{N} .67^{\circ} \mathrm{E}$. and dip about $77^{\circ} \mathrm{NW}$. to almost vertical.

\section{Composition}

The rock in the lower part of the Cherry Ridge redbed member is medium- to coarse-grained micaceous sandstone with small shale chips or clay galls; bedding ranges from thin and flaggy to thick and massive. Some of the lower beds are gray, resembling beds in the upper part of the Honesdale member, and some of these gray beds contain uraniferous rock. The uraniferous rock ranges from shale to pebbly coarse-grained sandstone but is mostly fine- to medium-grained sandstone. It is described in detail on pages 77-79.

A little higher in the section is a red and reddish-gray conglomeratic and sandy zone with pebbly lenses and crossbedded layers. Red sandstone grading to siltstone on top is interbedded with thick conglomerate and sandstone beds. Gray conglomerate and sandstone overlie the reddish-gray conglomerate zone. Above this is a thick section of red shale, siltstone, and sandstone with lesser amounts of 
greenish-gray beds. Graded bedding, crossbedding, lensing, and channeling are features of these upper beds.

The sandstone of the Cherry Ridge member is low-rank graywacke. The granular clastic fraction consists of quartz, rock fragments, accessory amounts of feldspar, and heavy minerals. Quartz is the most abundant granular component. In almost all samples the quartz grains are equant to elongate and angular to subrounded. A few of the beds have rounded to subrounded grains. Many of the quartz grains have irregular outlines, which indicates that they have undergone very little abrasion in their present grain size. In thin section the quartz grains show lines of pits or dusty inclusions, and areas of similar imperfections or impurities are common. Much of the quartz has wavy extinction and strain shadows. Very minute needle-shaped inclusions in quartz were seen in a few thin sections. Some of the quartz particles may be individual grains weathered from igneous or metamorphic rocks and may have undergone more than one cycle of sedimentary deposition. Many of the particles are similar in appearance to particles of quartz in larger grains or pebbles of quartzite. One of the sandstone beds is quartzitic and has interlocking grains of quartz and rock fragments cemented by silica.

Rock fragments make up a large percentage of the rock, almost equaling quartz in a few thin sections, but ranging from about 10 to 30 percent of the rock in most samples. In pebbly zones of the conglomerate, chips, pebbles, and cobbles of rock may exceed the finer grained fraction in volume. The coarse rock fragments are mostly well rounded or partly rounded; sand-size rock fragments have about the same degree of roundness as the quartz grains of the rocks in which they occur.

Rock fragments in the conglomerate include sandstone, siltstone, shale, quartzite, chert, vein quartz, and phyllite. No pebbles of igneous or high-grade metamorphic rocks were found, but some of the sandsize mineral grains came from such rocks. No evidence of more than one previous generation of sedimentary rocks was found. Red and nonred rock fragments occur in the conglomerate. The presence of red shale chips and red sandstone pebbles in rocks that have a reddishgray matrix, and in gray beds, indicates that the reddish hue in some of the beds is due to the color of the source material and not to oxidation of the sediments after deposition.

Relatively unaltered twinned grains of feldspar are rare in most samples of beds of the Cherry Ridge; such grains have low extinction angles. Sericitized grains or patches in some samples may be altered remnants of detrital orthoclase, microcline, and plagioclase feldspar; however, such material is not abundant enough for the sedimentary rock to be considered arkosic. 
Magnetite, ilmenite, leucoxene, tourmaline, and zircon are accessory minerals. Hornblende, apatite sphene, allanite, and garnet have been found in a few beds.

Micaceous and clayey minerals are a major constituent of almost all the rocks and form the principal bonding material. Muscovite occurs in flakes and thin bundles or books that bend around the granular minerals and are generally oriented parallel to bedding. These minerals probably are detrital. Somelarge flakes of chlorite may also be detrital. Sericite and chlorite, in much finer particles than the muscovite flakes, occur as a matted matrix interstitial to the granular minerals. In the finer grained rocks the granular minerals are more or less dispersed in the matrix. Chlorite is in pale-green irregular patches and in loose vermicular assemblages.

Red earthy iron oxide colors some of the rocks and makes up a few percent of the red beds. Brown iron oxide stains some of the weathered nonred beds.

Silica cement occurs in small amounts in a few beds, and calcite cements some of the uraniferous rock but is rare or absent in most of the beds.

X-ray spectrometer analysis of the clay-size fraction of samples of rocks from the Cherry Ridge member shows quartz, illite, chlorite, and $\mathrm{Fe}_{2} \mathrm{O}_{3}$ to be the major components.

\section{Distribution}

The outcrop area of the Cherry Ridge redbed member of the Catskill extends over about one-quarter of the project area, and the member underlies another quarter of the area. Because some of its beds are resistant, and because it lies between two very resistant units, the Honesdale member and the Pocono formation, the Cherry Ridge crops out along ridges and in uplands.

Its outcrop area includes the highest ground shown on plate 1Summer Mountain, the high areas near Julian Spring and between Mud Run and Pohopoco Mountain, Stony Ridge, Kettle Hill, the hill near Christman fire tower, the knob on Bear Mountain, and the crest of Mauch Chunk Ridge near Flagstaff. In contrast, however, the low swampy parts of the uplands are also in the outcrop area of red beds of the Cherry Ridge including the swamps at the head of Carpsrocus Creek, Yellow Run, Pinoak Run, Stony Creek, Panther Creek, Yost Swamp, and Mud Swamp. The Cherry Ridge redbed member is also exposed in the gorge of the Lehigh River in the western part of the project area and as an inlier west of Unionville.

One of the most distinctive features of the Cherry Ridge member is its coarse-grained red sandstone and red-matrix conglomerate. On Bear Mountain massive boulders of this conglomerate and blocks and slabs of red sandstone are exposed near the fire tower that is on the 
knob shown on the map as having an altitude of 1,685 feet. The conglomerate here has a greater percentage of pebbles than most of the Cherry Ridge conglomerates. The Cherry Ridge conglomerates probably thicken and thin considerably in short distances, although the beds are not exposed well enough to measure such changes.

Red siltstone and shaly beds are in the typical upper part of the Cherry Ridge member in sections exposed along the Lehigh River, but along Mud Run, just north of the northern edge of the mapped area, red coarse-grained sandstone of the Cherry Ridge grades into gray sandstone of the Pocono with no such fine-grained red rocks in the upper part of the Cherry Ridge. Near Penn Haven Junction, thick beds of fine-grained red rock occur in the upper part of the Cherry Ridge, but between these and the uraniferous beds lower in the member, most of the rock is gray and there are almost no red beds or conglomerate, except for a conglomeratic sandstone with a slightly red matrix exposed near river level. A few miles to the south, at the confluence of Bear Creek and the Lehigh River, there are red beds in the upper part of the member, but near river level there is a thick massive bed of gray coarse pebbly sandstone which resembles beds that are red elsewhere.

Drill core from a hole drilled through about 500 feet of the Cherry Ridge member and part of the Honesdale about 1,000 feet south of the junction of Bear Creek and Little Bear Creek was examined by the authors. The rock consists of red and gray sandstone, siltstone, and shale, and conglomerate with a red matrix. The section is similar to that along the Lehigh River.

The boundaries of the Cherry Ridge redbed member are mapped along zones where there is a change from the gray of adjoining beds to red or reddish gray. The Honesdale-Cherry Ridge contact is transitional and almost everywhere is a concealed boundary which can be located only approximately along zones where typical red Cherry Ridge sandstone is present in large amounts in the talus. A few outcrops have been found along these zones. The Cherry Ridge red sandstone generally weathers into blocky chunks with curved irregular outlines and rough sandy surfaces. The Honesdale gray sandstone that forms resistant talus weathers into blocky angular pieces and is generally more quartzitic than the rock of the Cherry Ridge.

Despite lithologic changes in the Cherry Ridge member and changes in color of the beds at the base and top of the unit, the color contrast was found to be the most useful means of delineating the boundaries of the formation, most of which are mapped as approximate contacts. Because the color and texture of these rocks vary, some of the beds at the top and bottom of the Cherry Ridge member may have been misidentified locally. Such errors, however, are within the acceptable limits for the scale of mapping used. 


\section{LOWER MISSISSIPPIAN SERIES}

\section{POCONO FORMATION}

A series of beds of gray sandstone, siltstone, and conglomerate totaling about 1,100 to 1,250 feet in thickness in the project area is assigned to the Pocono formation. The rocks weather to light gray and in places have a tan limonitic stain. The base of the Pocono is at the top of the uppermost red bed of the Catskill and the top of the Pocono is at the base of the lowermost red bed of the predominantly red Mauch Chunk formation. Approximately the same beds were assigned to the Pocono by Winslow (1887, p. 1363), who measured the Pocono section exposed along the Lehigh River near Jim Thorpe as 1,253 feet.

Leonard, ${ }^{3}$ who studied the section near Jim Thorpe as a type section of the Pocono and measured and described beds of the Pocono in detail, divided the formation into two units: a sandstone lower member and a conglomeratic upper member, which he called the Silkmill Run member and the Bear Mountain member, respectively. These units have been recognized and mapped in the project area, but Leonard's names are not considered satisfactory. The lower member is not exposed along Silkmill Run. The upper member does crop out on Bear Mountain but is less prominent than the conglomerate of the Cherry Ridge redbed member of the Catskill formation, which crops out on the summit of the mountain approximately in the area marked Bear Mtn. on the Lehighton quadrangle map. Although the authors have not used Leonard's terminology, they wish to acknowledge his recognition of lithologic units in the Pocono formation.

The fossil floras of the Pocono have been described by Read (1955), and the type section of the Pocono along the Lehigh River is cited by him and correlated with sections of the Pocono elsewhere in Pennsylvania.

A columnar section of the Pocono formation based on measurements of the section along the Lehigh River near Jim Thorpe is described in table 5 . The formation measured by the authors is about 1,100 feet thick, but almost 150 feet of gray beds mottled with red that underlie the section could be assigned to the lower part of the Pocono instead of to the Catskill which makes the total thickness about 1,250 feet and is in close agreement with Winslow's measurements. The mottled beds are red, gray, and green silty and pebbly sandstone with pebbles as much as about $1 \frac{1}{2}$ inches in diameter but mostly less than half an inch in diameter. There are some shaly to sandy thin red beds in this interval.

\footnotetext{
${ }^{3}$ Leonard, A. D., 1953, The Pocono sandstone neighboring the northern anthracite basin, Pennsylvania, a thesis: The Pennsylvania State College, Graduate School, Dept. of Earth Sciences, p. 1-27.
} 


\section{TABLE 5.-Section of Pocono formation of Early Mississippian age near Jim Thorpe,} Carbon County, Pa.

[Measured along base of Bear Mountain, south of Lehigh Valley railroad station on east side of Lehigh River. Measured by tape, corrected for deviation of traverse from strike and dip]

\begin{tabular}{|c|c|c|c|c|}
\hline \multirow{2}{*}{ Rock type and grain size } & \multirow{2}{*}{ Color } & \multirow{2}{*}{ Remarks } & \multicolumn{2}{|c|}{$\begin{array}{l}\text { Thickness } \\
\text { (in feet) }\end{array}$} \\
\hline & & & Unit & Total \\
\hline $\begin{array}{l}\text { Sandstone, siltstone, and con- } \\
\text { glomerate float. Top of } \\
\text { upper member of Pocono } \\
\text { formation. }\end{array}$ & Gray, greenis & $\begin{array}{l}\text { Mostly concealed. Top of } \\
\text { section is about } 150 \mathrm{ft} \text { south } \\
\text { of old foundation of water } \\
\text { tank, at base of red siltstone } \\
\text { and gray sandstone mottled } \\
\text { with red. }\end{array}$ & $143 \pm$ & $143 \pm$ \\
\hline $\begin{array}{l}\text { Coarse-grained sandstone } \\
\text { Coarse- to very coarse grained }\end{array}$ & $\begin{array}{l}\text { Gray } \\
\text { Light gray. }\end{array}$ & 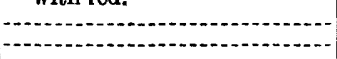 & $\begin{array}{l}13 \\
33\end{array}$ & $\begin{array}{l}156 \\
189\end{array}$ \\
\hline $\begin{array}{l}\text { sandstone. } \\
\text { Very coarse grained quartzitic } \\
\text { sandstone, conglomeratic at } \\
\text { top. }\end{array}$ & Gray... & Massive to thick-bedded. & 21 & 210 \\
\hline $\begin{array}{l}\text { Coarse- to medium-coarse- } \\
\text { grained micaceous sandstone; } \\
\text { siltstone. }\end{array}$ & -....do. & & 10 & 220 \\
\hline Sandstone and siltstone talus.-. & ......do.. & Mostly concealed. & 14 & 234 \\
\hline $\begin{array}{l}\text { stone. } \\
\text { Conglomerate. }\end{array}$ & 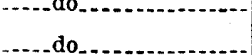 & -- & $\mathbf{3}$ & 239 \\
\hline $\begin{array}{l}\text { Coarse-grained micaceous sand- } \\
\text { stone. } \\
\text { Coarse- to very coarse grained }\end{array}$ & Light-brown & 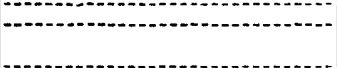 & 5 & 244 \\
\hline $\begin{array}{l}\text { sandstone. } \\
\text { Conglomerate }\end{array}$ & DIgLUL-DIOWL & & $\begin{array}{l}10 \\
21\end{array}$ & 254 \\
\hline Quartzitic conglomerate & Light gray. & Massive & 4 & 279 \\
\hline $\begin{array}{l}\text { Very coarse grained pebbly } \\
\text { sandstone. } \\
\text { Coarse to granular pebbly } \\
\text { quartzitic sandstone. }\end{array}$ & Gray, light & $\begin{array}{l}\text { Massive, gray shale chips on } \\
\text { top. }\end{array}$ & $\begin{array}{r}3 \\
21\end{array}$ & $\begin{array}{l}282 \\
303\end{array}$ \\
\hline Conglomerate............. & Gray & & 1 & 304 \\
\hline $\begin{array}{l}\text { Coarse-grained to pebbly quart- } \\
\text { zitic sondstone. }\end{array}$ & Light gray & Massive... & 7 & 311 \\
\hline $\begin{array}{l}\text { Conglomerate } \\
\text { Coarse-grained to }\end{array}$ & -...-do... & do... do & 3 & 314 \\
\hline $\begin{array}{l}\text { Carse-grained to conglomera- } \\
\text { tic sandstone. }\end{array}$ & $-\ldots-$. & Massive to thick-bedded. & & 331 \\
\hline $\begin{array}{l}\text { Coarse- to very coarse grained } \\
\text { sandstone. }\end{array}$ & .... do. & Thin-bedded.- & $\mathbf{3}$ & 334 \\
\hline $\begin{array}{l}\text { Coarse-grained to conglomera- } \\
\text { tic sandstone. }\end{array}$ & ......do.. & Massive to thick-bedded. & 31 & 365 \\
\hline $\begin{array}{l}\text { Medium- to coarse-grained mi- } \\
\text { caceous sandstone. }\end{array}$ & Gray & $\begin{array}{l}\text { "Dirty gray" thin to thick } \\
\text { bedded. }\end{array}$ & 7 & 372 \\
\hline $\begin{array}{l}\text { Coarse- to very coarse grained } \\
\text { and pebbly quartizitic sand- } \\
\text { stone. }\end{array}$ & Light gray & Massive.... & 7 & 379 \\
\hline $\begin{array}{l}\text { Conglomeratic sandstone and } \\
\text { conglomerate. }\end{array}$ & Gray. & .....do.. & 49 & 428 \\
\hline $\begin{array}{l}\text { Coarse conglomerate } \\
\text { Coarse- to very coarse grained }\end{array}$ & do... & Massive, iregular fractures..... & $\begin{array}{l}19 \\
12\end{array}$ & $\begin{array}{l}447 \\
459\end{array}$ \\
\hline $\begin{array}{l}\text { micaceous quartzitic sand- } \\
\text { stone. }\end{array}$ & & & & \\
\hline $\begin{array}{l}\text { Coarse-grained quartzitic sand- } \\
\text { stone. }\end{array}$ & Gray. & $\begin{array}{l}\text { Massive. "Trashy" with } \\
\text { shale patches, pyrite nodules. }\end{array}$ & 18 & 477 \\
\hline $\begin{array}{l}\text { Coarse- to very coarse grained } \\
\text { sandstone, locally pebbly. }\end{array}$ & $\begin{array}{l}\text { Light-brownish to } \\
\text { whitish gray. }\end{array}$ & $\begin{array}{l}\text { Irregular and massive, pyrite } \\
\text { nodules } 1 \text { to } 3 \mathrm{in.} \text { in diam. }\end{array}$ & 13 & 490 \\
\hline $\begin{array}{l}\text { Coarse- to very coarse-grained } \\
\text { and pebbly sandstone, mica- } \\
\text { ceous and quartzitic. }\end{array}$ & Light gray... & Pebbly in lower part & 7 & 497 \\
\hline Shale. & Black --: & Fragmental plant fossils.......- & 3 & $\begin{array}{l}500 \\
505\end{array}$ \\
\hline $\begin{array}{l}\text { Very coarse grained pebbly } \\
\text { sandstone. }\end{array}$ & & 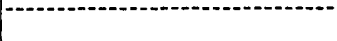 & & \\
\hline $\begin{array}{l}\text { Coarse conglomerate and con- } \\
\text { glomeratic sandstone. }\end{array}$ & Gray.-.- & & 34 & 539 \\
\hline $\begin{array}{l}\text { Very coarse grained pebbly } \\
\text { sandstone. }\end{array}$ & $\begin{array}{l}\text { Light-brownish gray, } \\
\text { white. }\end{array}$ & & 8 & 547 \\
\hline Conglomerate..........- & Gray--.... & $\begin{array}{l}\text { Quartz pebbles coarser in low* } \\
\text { er part. }\end{array}$ & 9 & 556 \\
\hline $\begin{array}{l}\text { Coarse-grained pebbly sand- } \\
\text { stone. } \\
\text { Shale and sandstone.............. }\end{array}$ & $\ldots d c$ & $\begin{array}{l}\text { Pebbles in layers } \\
\text { Abundant fragmental plant }\end{array}$ & $\begin{array}{r}14 \\
2\end{array}$ & $\begin{array}{l}570 \\
572\end{array}$ \\
\hline
\end{tabular}


TaBle 5.-Section of Pocono formation of Early Mississippian age near Jim Thorpe, Carbon County, Pa.-Continued

\begin{tabular}{|c|c|c|c|c|}
\hline \multirow{2}{*}{ Rock type and grain size } & \multirow{2}{*}{ Color } & \multirow{2}{*}{ Remarks } & \multicolumn{2}{|c|}{$\begin{array}{l}\text { Thickness } \\
\text { (in feet) }\end{array}$} \\
\hline & & & Unit & Total \\
\hline $\begin{array}{l}\text { Medium- to coarse-grained mi- } \\
\text { caceous quartzitic sandstone. }\end{array}$ & Gray... & $\begin{array}{l}\text { Plant stem fossils. "Trashy" } \\
\text { layer on top. pitted from } \\
\text { weathering of sparse pyrite } \\
\text { nodules. }\end{array}$ & 13 & 585 \\
\hline $\begin{array}{l}\text { Coarse- to very coarse grained } \\
\text { quartzitic sandstone. }\end{array}$ & -.... do.. & Thick bedded.................. & 9 & 894 \\
\hline $\begin{array}{l}\text { Medium- to coarse-grained mi- } \\
\text { caceous and quartzitic sand- } \\
\text { stone. }\end{array}$ & .....do. & Massive.... & 13 & 607 \\
\hline $\begin{array}{l}\text { Conglomerate and very coarse } \\
\text { grained sandstone. }\end{array}$ & -....do. & -- & 4 & 611 \\
\hline Very coarse to granular quartz- & Light-brownish gray.- & Massive_............. & 11 & 622 \\
\hline $\begin{array}{l}\text { snaly sandstone. } \\
\text { itic siltstone and very fine } \\
\text { grained sandstone. }\end{array}$ & Gray & Fragmental plant fossils.... & 11 & 633 \\
\hline $\begin{array}{l}\text { Very coarse grained quartzitic } \\
\text { sandstone. }\end{array}$ & Light gray. & Irregular bedding... & 2 & 635 \\
\hline $\begin{array}{l}\text { Shale and very fine grained } \\
\text { shaly sandstone. }\end{array}$ & Gray. & & 4 & 639 \\
\hline $\begin{array}{l}\text { Coarse- to medium-grained mi- } \\
\text { caceous and quartzitic sand- } \\
\text { stone. }\end{array}$ & .....do.. & Massive to thick bedded.... & 12 & 651 \\
\hline $\begin{array}{l}\text { Coarse-grained and pebbly } \\
\text { quartzitic sandstone. }\end{array}$ & ....... do & Massive & 23 & 674 \\
\hline Shale & Black & Fragmental plant fossils... & 2 & 678 \\
\hline $\begin{array}{l}\text { Coarse-grained quartzitic sand- } \\
\text { stone, fine-grained sandstone } \\
\text { on top. }\end{array}$ & Gray-..- & $\begin{array}{l}\text { Massive, pitted due to } \\
\text { weathering of sparse pyrite } \\
\text { nodules. }\end{array}$ & 7 & 683 \\
\hline $\begin{array}{l}\text { Conglomerate, coarse-grained } \\
\text { pebbly sandstone on top. } \\
\text { Base of upper member of Po- } \\
\text { cono formation. }\end{array}$ & $\ldots . . .-d$ & Massive & 17 & $700 \pm$ \\
\hline $\begin{array}{l}\text { Shaly siltstone. Top of lower } \\
\text { member of Pocono formation. }\end{array}$ & $\begin{array}{l}\text { Olive, light-brownish } \\
\text { gray. }\end{array}$ & $\begin{array}{l}\text { Underlies thick massive con- } \\
\text { glomerate of upper member } \\
\text { of Pocono formation. }\end{array}$ & 2 & 2 \\
\hline $\begin{array}{l}\text { Coarse- to fine-grained silty } \\
\text { sandstone. }\end{array}$ & Gras & $\begin{array}{l}\text { Grain size diminishes toward } \\
\text { top. }\end{array}$ & 8 & 10 \\
\hline $\begin{array}{l}\text { Coarse-grained to pebbly } \\
\text { quartzitic sandstone. }\end{array}$ & $\ldots-.-d$ & $\begin{array}{l}\text { Massive 6-in. shaly very fine } \\
\text { grained sandstone layer on }\end{array}$ & 19 & 29 \\
\hline $\begin{array}{l}\text { Siltstone and very fine grained } \\
\text { sandstone. }\end{array}$ & Light-brownish gray. - & 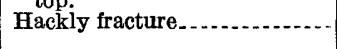 & 5 & 34 \\
\hline $\begin{array}{l}\text { Medium-to medium-fine- } \\
\text { grained sandstone. }\end{array}$ & Gray. & $\begin{array}{l}\text { Spheroidal or curved weath- } \\
\text { ered zones. }\end{array}$ & $\mathbf{5}$ & 39 \\
\hline $\begin{array}{l}\text { Siltstone and very fine grained } \\
\text { sandstone. }\end{array}$ & $\begin{array}{l}\text { Olive to brownish } \\
\text { gray. }\end{array}$ & $\begin{array}{l}\text { Sandy lenses, ovoid concre- } \\
\text { tions spheroidal weathering, } \\
\text { cleaved layers. }\end{array}$ & 64 & 103 \\
\hline $\begin{array}{l}\text { Coarse-grained quartzitic sand- } \\
\text { stone. }\end{array}$ & & $\begin{array}{l}\text { Massive, shaly parting } 1 \mathrm{ft} \\
\text { from top. }\end{array}$ & 48 & $15 \%$ \\
\hline Fine granular conglomerate & 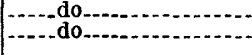 & $--\cdot$ & $\mathbf{2}$ & $\begin{array}{l}153 \\
166\end{array}$ \\
\hline $\begin{array}{l}\text { Coarse-grained quartzitic sand- } \\
\text { stone. }\end{array}$ & .....do & $\begin{array}{l}\text { Massive to blocky; pyrite } \\
\text { nodules. }\end{array}$ & 3 & 169 \\
\hline $\begin{array}{l}\text { Fine- to medium-grained sand- } \\
\text { stone, siltstone. }\end{array}$ & $-\ldots$ & Massive......... & 11 & 180 \\
\hline $\begin{array}{l}\text { Very fine to fine-grained sand- } \\
\text { stone; pebbly sandstone. }\end{array}$ & $\cdots$ & Pebbly in upper part. & 3 & 183 \\
\hline $\begin{array}{l}\text { Medium- to fine-grained mica- } \\
\text { ceous quartzitic sandstone, } \\
\text { pebbly at base. }\end{array}$ & Gray, light gray. & $\begin{array}{l}\text { Massive in upper part; pyrite } \\
\text { nodules in lower part. }\end{array}$ & 20 & 203 \\
\hline $\begin{array}{l}\text { Medium-grained micaceous } \\
\text { sandstone. }\end{array}$ & G & Massive.. & $\mathbf{5}$ & 208 \\
\hline Medium- to fine-grained & .....do. & Massive, hard................... & 5 & 213 \\
\hline $\begin{array}{l}\text { Medium-grained silty mica- } \\
\text { ceous sandstone. }\end{array}$ & & Thin-bedded to blocky, weak. & 12 & 225 \\
\hline $\begin{array}{l}\text { Medium- to coarse-grained } \\
\text { quartritic sandstone. } \\
\text { Fine-grained sandstone. }\end{array}$ & 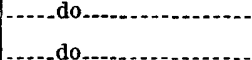 & Massive.... & 9 & 234 \\
\hline $\begin{array}{l}\text { Medium to fine-grained } \\
\text { quartzitic sandstone. }\end{array}$ & & $\begin{array}{l}\text { Massive, finer grained near } \\
\text { top. }\end{array}$ & 15 & 253 \\
\hline $\begin{array}{l}\text { Fine-to very fine-grained mica- } \\
\text { ceous sandstone. }\end{array}$ & $\ldots d$ & Spheroidal weathering... & 8 & 261 \\
\hline
\end{tabular}


TABLE 5.-Section of Pocono formation of Early Mississippian age near Jim Thorpe, Carbon County, Pa.-Continued

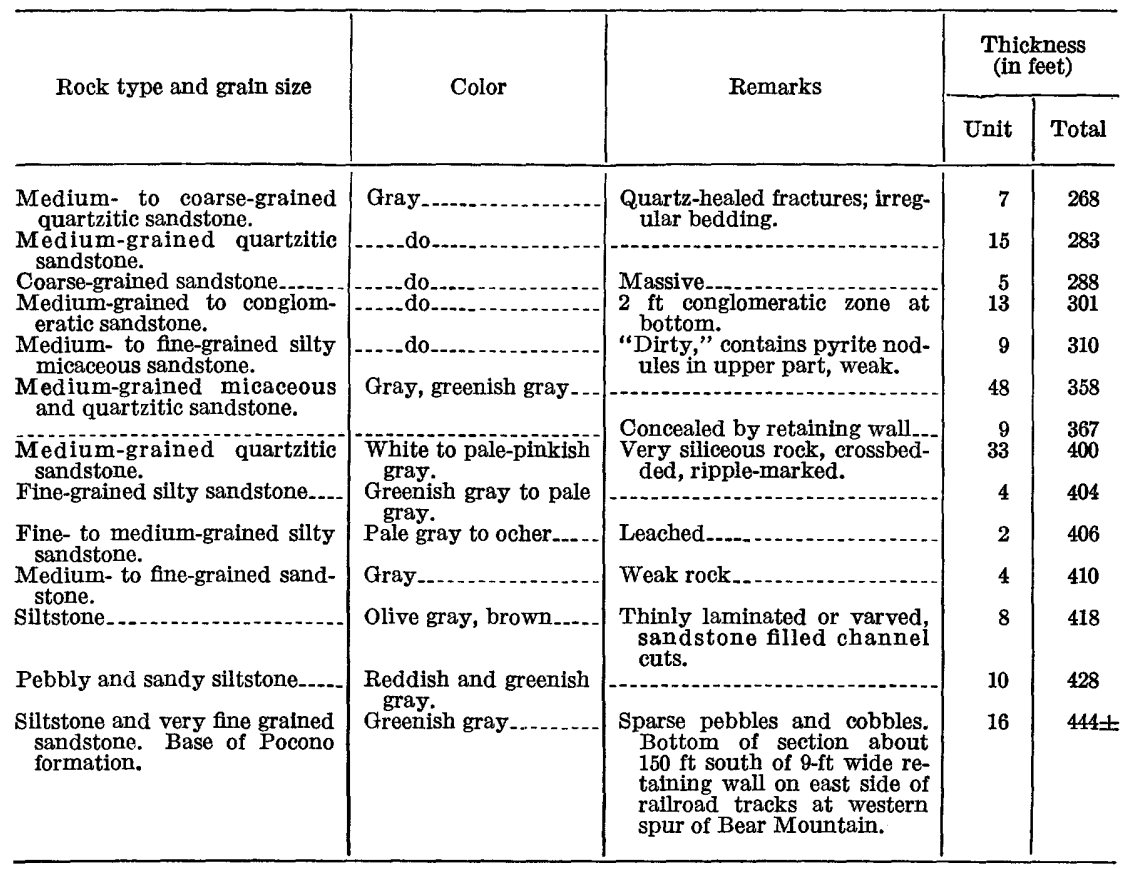

The lower member of the Pocono formation was calculated to be about 444 feet thick, which is in close agreement with Leonard's ${ }^{4}$ measurements of his Silkmill Run member, but about 30 to 40 feet of beds that he assigns to the Catskill are included in the Pocono by the authors.

The upper member of the Pocono is about 700 feet thick, but the uppermost 100 feet or so of the section is poorly exposed and the position of the lowermost red bed of the Mauch Chunk cannot be located precisely. In fact, a mottled reddish-gray sandstone that is assigned by the authors to the upper part of the upper member, because of its appearance and overall properties, might be assigned to the Mauch Chunk by others because of its color.

The Pocono formation thins to the north and is only about 500 to 600 feet thick in the area north of Penn Haven Junction and on the north side of Summer Mountain. Both the upper and lower members of the Pocono are thinner in these areas than they are at the type locality near Jim Thorpe.

4 Leonard, A. D., 1953, The Pocono sandstone neighboring the northern anthracite basin, Pennsylvania, a thesis: The Pennsylvania State College, Graduate School, Dept. of Earth Sciences, p. 1-27. 


\section{Composition}

The lower member of the Pocono formation, in the type section, consists of gray sandstone, siltstone, and shale. Near the base the rock is silty and shaly. Above this is a bed of white to whitish-gray medium-grained quartzitic sandstone that is medium to thick bedded and very siliceous and has ripple marks in the lower part. Greenishgray micaceous and silty sandstone, which locally contains sparsely disseminated pyrite nodules that are as much as about 2 inches in diameter, make up most of the member.

The upper member of the Pocono is mostly coarse-grained sandstone and conglomerate. The base of the member is at the base of a massive bed of coarse conglomerate about 20 feet thick. Above this is coarsegrained massive gray sandstone, dark-gray silty sandstone, and shaly siltstone. Thick beds of massive conglomerate occur at intervals in the upper part of the section. The conglomeratic beds vary noticeably in thickness from place to place, and, locally, some grade into pebbly or coarse sandstone. Pyrite nodules are abundant in sandstone and conglomeratic sandstone. There are some beds of coarse-grained micaceous gray sandstone with numerous shale chips or clay galls a Jew inches in diameter in the upper member. Fragmental plant fossils occur in many of the beds, and some large fossils of roots or stems are a few inches wide.

The rocks of the Pocono are low-rank graywacke and quartzite. The granular detrital components are quartz and quartzite, chert,and other rock fragments, and very minor amounts of feldspar and accessory minerals. The granular material makes up about 35 to 95 percent of the graywacke, and clastic grains with thick overgrowths of silica make up about 80 to 95 percent of the quartzite beds. The grains are equant to elongate and well rounded to angular and irregular in outline. Sorting is fair to very poor.

Quartz is the most abundant of the granular materials, ranging from about 35 to 70 percent of the rock. Much of it is fragments of vein quartz and some of it probably is small particles of grains from coarse-grained quartzite. Part of the quartz may have come from igneous or high-grade metamorphic rocks. In thin section many of the quartz grains show strain shadows or wavy extinction, some have lines of pits or tiny inclusions, and others have irregular fracture networks.

Quartzitic rock fragments are the second most abundant granular material in the formation, ranging from about 1 to 50 percent of the rock in the thin sections. Chert, quartz-sericite schist, and phyllite rock fragments range from less than 1 percent to about 16 percent of the rock, with chert the most abundant of these. 
Twinned feldspar is not present or is rare in most thin sections. A few partly seriticized grains that may be remnants of feldspar grains were seen in the thin sections.

Flakes of muscovite, biotite, and shreds or patches of hydromica and chlorite are the coarser micaceous materials. Sericite, chlorite, and minute particles of quartz form the matrix. Sericite is the most abundant of these, but particles of quartz are very abundant in the matrix of some of the conglomeratic or pebbly rocks. Chlorite is in irregular patches and in tiny vermicular aggregates.

Black opaque minerals, probably magnetite and ilmenite, and leucoxene, zircon, tourmaline and sparse grains of hornblende, pyroxene, and unidentified partly altered minerals are the accessory and trace constituents. Limonite stains some of the weathered rock.

Quartz, illite, chlorite, and possibly dolomite and siderite were identified by X-ray spectrometer analysis of the clay-size fraction of samples of sandstone of the Pocono.

Silica is an abundant cementing material in the rocks of the Pocono. Some of the quartzitic rock is more than 90 percent siliceous grains and is cemented by silica, and small amounts of silica cement graywacke that is banded by the micaceous and clayey matrix material. This makes the rocks of the Pocono relatively inert and resistant to weathering.

\section{Distribution}

The outcrop area of the Pocono formation is about 39 square miles, and the formation underlies younger formations in about 13 square miles, all in the western half of the project area.

The siliceous rocks of the Pocono are very resistant to weathering, and they cap high areas and rim synclinal valleys. Parts of Summer Mountain, Bald Mountain, Scrub Mountain, Broad, Pocono, and Bear Mountains, and the northern flank of Mauch Chunk Ridge are underlain by the upper member of the Pocono. Adjoining areas with about equal altitudes are underlain by the lower member of the Pocono.

The Pocono-Catskill contact is mapped along a zone between predominantly red beds of the Cherry Ridge and gray siliceous beds of the Pocono. This contact is somewhat transitional. The mottled gray and red pebbly and silty sandstone below the entire nonred section of the Pocono as described in the Lehigh River section, and the very siliceous quartzitic sandstone bed in the lower part of the lower member of the Pocono have been recognized in many places. The latter bed has ripple- or oscillation-marked surfaces on closely spaced layers, and these give it a distinctive appearance in outcrop. 
The boundary between the lower and upper members of the Pocono, as mapped, is an approximate boundary, confirmed at intervals where the thick basal conglomerate of the upper member crops out Boulders of conglomerate moved by glacial activity and by gravity are spread beyond the limits of the areas underlain by the upper member. A zone of pebbly sandstone about 20 to 50 feet below the thick basal conglomerate bed of the upper member is conglomeratic in some places. Locally this conglomeratic bed is 2 to 5 feet thick, but it is not so prominent in outcrop as the more persistent thick basal unit of the upper member.

At Penn Haven Junction the basal conglomerate bed of the upper member is exposed high on the hillside west of the signal tower and south of Black Creek, but on the east side of the river the rock is pebbly sandstone. The basal conglomerate bed of the upper member crops out also near the top of the steep slope south of Mud Run near the northern edge of the Lehighton quadrangle. It is less prominent a few miles to the southwest on Summer Mountain, but is very distinctive on the west side of the Lehigh River south of Unionville and at the type section near Jim Thorpe.

Coarse white pebbles as much as a few inches in dameter, but usually about half an inch in diameter, are very abundant in some beds. A distinctive bed of very pebbly quartzitic conglomerate with pebbles about $1 / 4$ to $\frac{1}{2}$ inch in diameter is exposed in the Pocono along Stony Creek. Shaly and silty beds, some with plant fossils, are also exposed in this stream valley.

A bed of pyritiferous conglomerate with quartz pebbles and a matrix almost entirely of pyrite occurs locally in the upper member of the Pocono. It is well exposed in the railroad cut on the northwest side of the Lehigh River near the railroad tunnel west of the borough of East Mauch Chunk (now part of Jim Thorpe). Another good exposure of the pyritiferous conglomerate is in a streambed near the railroad tracks on the south side of the Lehigh River about 1 mile east of Rockport.

On Broad Mountain, just west of the Lehigh River, resistant quartzitic beds of the lower member of the Pocono crop out in small ridges. Some of the rock appears to have been tilted or shifted by glaciation, and in the low areas between the small ridges, rock streams of gray sandstone of the Pocono trend eastward to the edge of the gorge of the Lehigh River.

The Pocono formation forms the crest of the northern spur of Mauch Chunk Ridge south of Jim Thorpe. A short distance west of the river the Pocono crops out on the north slope of the ridge, but not at the ridge top. Similarly, the Pocono crops out on the north slope of Bear Mountain and it caps Pocono Mountain.

$675114-63-4$ 


\section{UPPER MISSISSIPPIAN SERIES}

MAUCH CHUNK FORMATION

The Mauch Chunk formation of Late Mississippian age overlies the Pocono and underlies the Pottsville formation in the project area. The formation is named for the section exposed along the Lehigh River near Jim Thorpe (formerly Mauch Chunk) in Mauch Chunk Township, Carbon County, Pa. The Mauch Chunk, as mapped in this area, includes about 1,700 feet of red beds and about 500 feet of interlayered red and gray beds in almost equal amounts in a transition zone at the top. Winslow $(1887$, p. 1363) assigned a thickness of 2,168 feet to the thick red bed section below the transition zone in this area, but this is probably excessive.

The bottom of the formation crops out about 600 feet south of the railroad tunnel along the tracks of the Central Railroad of New Jersey about 2,000 feet north-northwest of the confluence of Nesquehoning Creek and the Lehigh River, near the western edge of the project area. The top of the formation is concealed, but the uppermost red beds that were exposed at an altitude of almost 1,000 feet in excavation for a drilling site on the north side of Mount Pisgah are approximately at the top of the formation. After corrections for dip and strike, and for differences in altitude between the outcrops of the base and top of the formation, a thickness of about 2,200 feet is calculated.

A columnar section of the Mauch Chunk formation, based on the section exposed along the Lehigh River near Jim Thorpe, is described in table 6. The Mauch Chunk-Pottsville transition zone in the mapped area occurs only on Mount Pisgah and except for the basal bed is poorly exposed. The section of the transition zone given in table 6 is, therefore, from logs of drill core measured by Gault and others (1957, p. 114-119).

The inclusion of the transition zone in the Mauch Chunk is an arbitrary matter. There is precedent in the literature both for including and for excluding the zone. The intermittent signs of beginning of deposition of new types of sediments under new conditions may be used to delineate the base of a formation, or evidence of the intermittent continuance of an older type of sedimentation may be cited as a reason for including rock of a different type in the upper part of a formation. Assigning the beds of the transition zone to either the Mauch Chunk or the Pottsville formation also involves a choice between geologic periods. 
TABLE 6.-Section of Mauch Chunk formation of Late Mississippian age near Jim Thorpe, Carbon County, Pa.

\begin{tabular}{l|l|l|l|l}
\hline Rock type and grain size & Color & Remarks & \multicolumn{2}{c}{$\begin{array}{c}\text { Thickness } \\
\text { (in feet) }\end{array}$} \\
\hline
\end{tabular}

Mauch Chunk-Pottsville transition zone

[Based on logs by Gault and others (1957, p. 114-119) of core from drill holes on north slope of Mount P1sgah, west of area mapped in pl. 1]

\begin{tabular}{|c|c|c|c|c|}
\hline Shale and siltstone. & Red. & Top of section concealed........ & & 7 \\
\hline Shale and siltstone, micaceous. & Gray-- & & 8 & 16.8 \\
\hline Conglomerate. &...- & $\begin{array}{l}\text { Limestone and dolomite peb- } \\
\text { bles, calcareous matrix. }\end{array}$ & 7.4 & 24.2 \\
\hline Shale and siltstone. & Red & 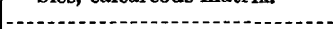 & 4. 9 & 29.1 \\
\hline Sandstone and shale & Gray, maroon gray.... & & 38.6 & $67 . \overline{7}$ \\
\hline rate. & - & $\begin{array}{l}\text { Quartzite, siltstone, and shale } \\
\text { pebbles. }\end{array}$ & 53.3 & 121.0 \\
\hline Shale. & & & 2.7 & 123.7 \\
\hline Shale, siltstone, and sandstone & Red... & 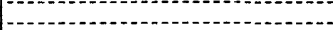 & 33.9 & 157.6 \\
\hline $\begin{array}{l}\text { Sandstone, conglomerate in } \\
\text { lower } 5 \mathrm{ft} \text {. }\end{array}$ & Gray & - & 27.7 & 185. 3 \\
\hline Shale......... & - ao & & 2.7 & 188.0 \\
\hline Sandstone...- & do & & 7.2 & 195.2 \\
\hline Shale & Red & - & 19. 1 & 214.3 \\
\hline Siltstone & do do & Jimestane and dolomite neb- & 5.4 & 219.7 \\
\hline lomerate..................... & Gray $\ldots \ldots$ & $\begin{array}{l}\text { Limestone and dolomite peb- } \\
\text { bles, red matrix. }\end{array}$ & 1.5 & 221.2 \\
\hline in lower $5 \mathrm{ft}$ & Red. & 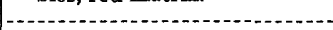 & 12.6 & 233. 8 \\
\hline---1 & Gray, black...... & - & 10.6 & 244. \\
\hline in lower third. & Red, gray............. & 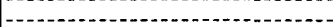 & 16.4 & 260.8 \\
\hline$-2-2-2$ & Gray & $-\ldots$ & 5.7 & 266.5 \\
\hline and siltstone. & Red & |-. & 107.8 & 374.3 \\
\hline dstone. & Maroon, gray & 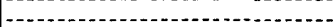 & 17. 7 & 392.0 \\
\hline Shale.... & Red & - & 18.8 & 410.8 \\
\hline Siltstone; sandstone, in lower & Maroon & & 31.5 & 442.3 \\
\hline tone... & Gray & |-nen & 14. 7 & 457 \\
\hline $\begin{array}{l}\text { Conglomerate. Base of } \mathrm{Mauch} \\
\text { Chunk-Pottsville transition } \\
\text { zone. }\end{array}$ & - & 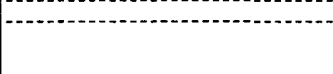 & 52.3 & 509. \\
\hline
\end{tabular}

Main body of red beds in Mauch Chunk formation

[Measured along U.S. Route 309 from northwest side of triangular raillroad building at foot of Mount Pisgah near axis of syncline southeastward to outcrop north of post office building]

Siltstone.-.
Fine- to medium-grained sand-
stone and siltstone.
Fine to very fine grained sand-
stone, siltstone, and mud-
stone.
Silty mudstone, siltstone, very
fine grained sandstone.
Very fine grained micaceous
sandstone.

Mudstone and siltstone

Fine- to medium-grained $\mathrm{ml}$ caceous sandstone.

Siltstone to very fine grained micaceous sandstone.

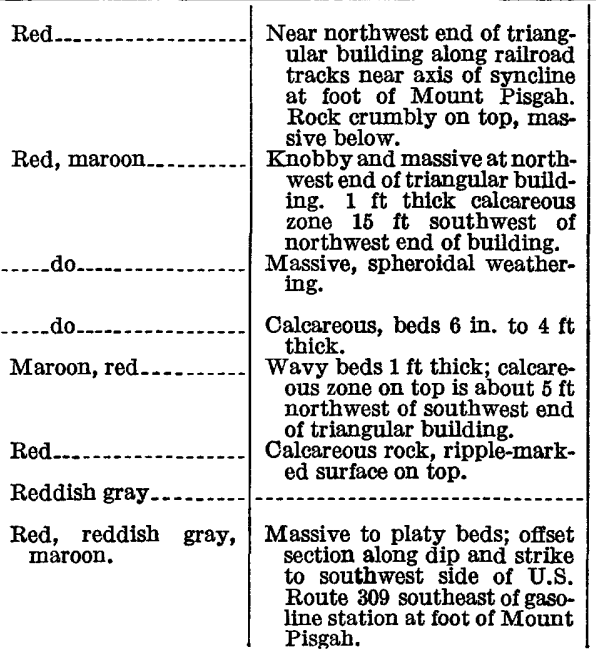


TABLE 6.-Section of Mauch Chunk formation of Late Mississippian age near Jim Thorpe, Carbon County, Pa.-Continued

\begin{tabular}{l|l|l|l|l}
\hline Rock type and grain size & Color & Remarks & \multicolumn{2}{c}{$\begin{array}{c}\text { Thickness } \\
\text { (in feet) }\end{array}$} \\
\hline
\end{tabular}

Main body of red beds in Mauch Chank formation-Continued

Fine- to medium-grained micaceous sandstone.

Shale shale chips.

Fine- to medium-grained micaceous sandstone; siltstone.

Fine-grained purplish sand. stone.

Siltstone and mudstone.

Medium grained micaceous sandstone.

Mudstone, siltstone, very fine grained sandstone.

Fine- to medium-grained sandstone.

Siltston.

Fine- to medium-grained sandstone; mudstone.

Medium- to fine-grained sandstone.

Siltstone

Medium-grained micaceous sandstone.

Siltstone

Medium- to fine-grained sandstone.

Siltstone to medium-grained sandstone.

Very fine grained sandstone with silty or shaly partings.

Medium-to coarse-grained micaceous sandstone.

Siltstone to very fine grained sandstone.

Medium-grained sandstone..

Calcareous siltstone

Siltstone.

Fine- to medium-grained micaceous sandstone with red shale chips.

Very fine to medium-grained sandstone and siltstone.

Fine- to medium-grained micaceous sandstone; siltstone.

Fine-grained sandstone

Fine- to medium-grained sandstone with siltstone partings.

Medium- to fine-grained sand. stone.

Fine- to medium-grained sandstone.

Intraformational conglomerate of white to pinkish-gray calcareous sandy pebbles in red silt and clay matrix.

Very fine to medium-grained sandstone with thin calcareous layers in lower part.

Conglomerate and very coarse grained sandstone with calcareous nodules.

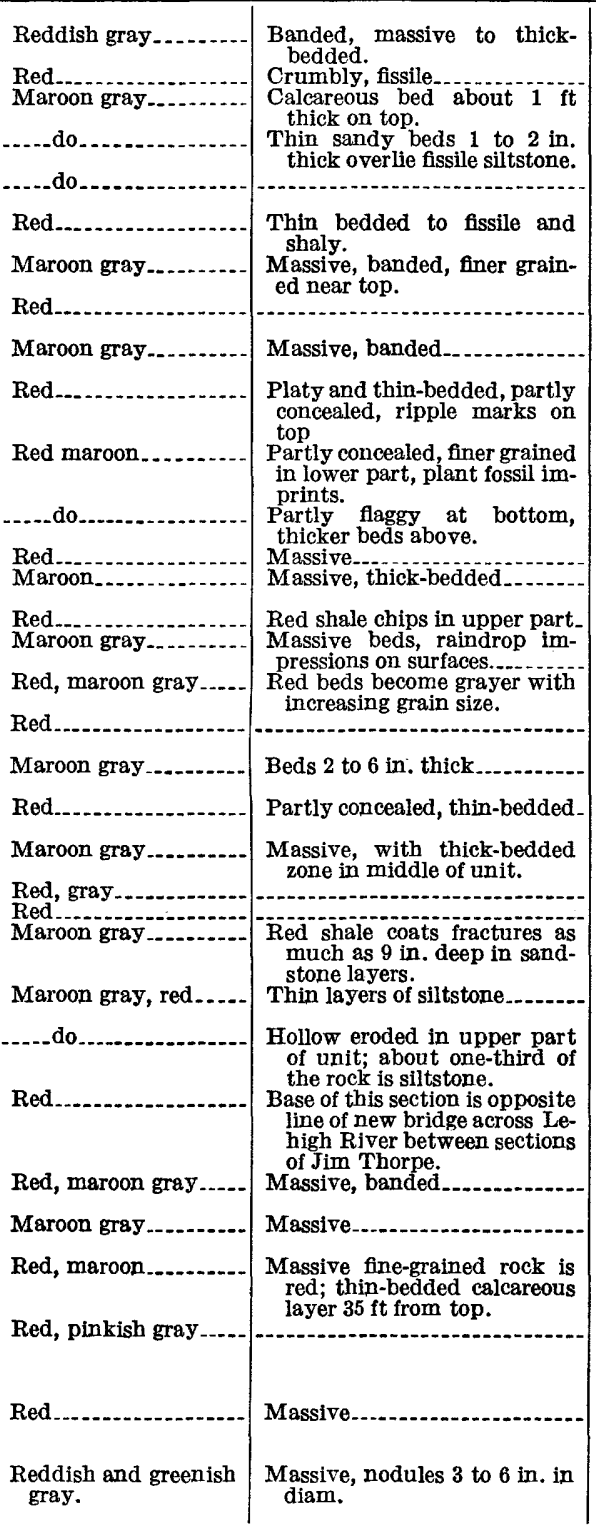


TABLE 6.-Section of Mauch Chunk formation of Late Mississippian age near Jim Thorpe, Carbon County, Pa.-Continued

\begin{tabular}{|c|c|c|c|c|}
\hline \multirow{2}{*}{ Rock type and grain size } & \multirow{2}{*}{ Color } & \multirow{2}{*}{ Remarks } & \multicolumn{2}{|c|}{$\begin{array}{l}\text { Thickness } \\
\text { (in feet) }\end{array}$} \\
\hline & & & Unit & Total \\
\hline \multicolumn{5}{|c|}{ Main body of red beds in Mauch Chunk formation-Con tinued } \\
\hline Sandstone... & Reddish gray & & 8 & 1,500 \\
\hline $\begin{array}{l}\text { Medium- to coarse-grained } \\
\text { sandstone. }\end{array}$ & Red, maroon gray, & $\begin{array}{l}\text { Massive, banded, gradational } \\
\text { color changes, lensing sand } \\
\text { layer in upper part. }\end{array}$ & 41 & 1,541 \\
\hline $\begin{array}{l}\text { Mudstone to medium-coarse } \\
\text { grained sandstone. }\end{array}$ & Gray, maroon & $\begin{array}{l}\text { Massive, banded } \\
\text { Coarser grained toward bot- } \\
\text { tom. }\end{array}$ & 25 & $\begin{array}{l}1,548 \\
1,573\end{array}$ \\
\hline Mudstone and shale; siltstone... & $\begin{array}{l}\text { Red, olive tan, green- } \\
\text { ish gray. }\end{array}$ & Hackly fracture in red beds.. & 87 & 1,660 \\
\hline $\begin{array}{l}\text { Coarse-grained sandstone.......- } \\
\text { Shale. }\end{array}$ & Tan & Massive, weak punky.......... & 21 & 1,681 \\
\hline Coarse-grained sandstone.-.......... & Light-brownish gray.-. & $\begin{array}{l}\text { Partly hard, partly punky } \\
\text { weak rock. Concealed be- } \\
\text { low. This bed may besame } \\
\text { as thick sandstone bed un- } \\
\text { derlain by thin red to pur- } \\
\text { ple and green shale at base of } \\
\text { Mauch Chunk formation in } \\
\text { areas to the north. About } \\
\text { 175 ft south to parking area } \\
\text { at gasoline station north of } \\
\text { post office. }\end{array}$ & 16 & 1,734 \\
\hline
\end{tabular}

If it is to be decided on evidence available in one quadrangle area, the matter will be in doubt. The Mauch Chunk thins to the north, as does the Pottsville. The thinning of the Mauch Chunk may be due to erosion or to nondeposition, or to both. Some of the conglomeratic beds of the transition zone on Mount Pisgah contain chips and fragments of red shale and sandstone and red fine-grained matrix material mixed with gray quartz pebbles and fragments of red beds. The red material may have been eroded from part of the Mauch Chunk, or from some older formation, and intermixed and deposited with the gray clastic rocks of the Pottsville source material. Thus, there is the possibility that the transition zone may be post-Mauch Chunk, but a regional study would be needed to determine this. Paleobotanical evidence may be of use in solving this problem when more is learned about the fossil flora of these rocks.

In this report the transition zone is included in the Mauch Chunk in order that the units will correspond with those that have been mapped by Wood and others (1956) in the Middle anthracite fields. Only a small part of the project area is involved, as the transition zone extends only to the west side of the Lehigh River at the foot of Mount Pisgah.

The uranium occurrence on Mount Pisgah, which was previously described as being in the Pottsville formation by the authors cited in the introduction, is in the transition zone and is here assigned to the 
Mauch Chunk, but should not be referred to as being in shale of the Mauch Chunk, for the uraniferous rock is medium- to coarse-grained gray sandstone and quartz pebble conglomerate. There is no known uraniferous red rock in the deposit.

\section{Composition}

The rocks of the Mauch Chunk formation are mostly sandstone, siltstone, and shale that can be classified as low-rank graywacke. At the base of the formation, a purplish-red to greenish-gray bed of fissile shale 1 to 2 feet thick underlies a massive bed 15 to 20 feet thick of coarse-grained poorly cemented gray to brownish-gray sandstone that is pebbly and almost conglomeratic in some places. Above this are red shaly siltstone, fine-grained sandstone, and mudstone interlayered with olive-drab or greenish-tan siltstone and gray-tan sandstone.

Massive red medium- to coarse-grained sandstone occurs higher in the section. Pinkish-gray calcareous sandstone, which may be sandy limestone in part, occurs in beds less than 1 foot to almost 4 feet thick. Some of this rock is in rounded irregular pieces with red silty clay forming a matrix. Other beds are conglomeratic, with rounded limy sandstone fragments in red silty sandstone. Above these are thick and massive beds of red silty sandstone separated by red shaly partings or thin beds of siltstone. In the upper part of the thick red-bed section, there is red micaceous sandstone, some with ripple-marked surfaces and some with red clay-filled mud cracks. Imprints of plant fossils occur in these beds. A few pinkish-gray calcareous beds, similar to those lower in the formation, occur near the top of the thick section of red beds, and red shale, siltstone, and silty mudstone are abundant in the upper part.

Some megascopic features of the Mauch Chunk formation that distinguish it from the older formations in this general area are its lightcolored calcerous layers and its very thick individual red beds, some of which are as much as 100 feet thick. In thin section, it is strikingly different from the underlying rocks. Fresh-looking twinned feldspar is more abundant, and there is a greater variety and abundance of accessory minerals that were derived from igneous or high-grade metamorphic rocks. Fragments of calcite are common, and calcite cement is present in many beds and very abundant in some. The suite of thin sections examined were of sandstones and a few sandy siltstones taken from the thick series of red beds.

Quartz, quartzitic rock fragments, and chert are the most abundant granular materials. Quartz makes up about 15 to 50 percent of the rock, generally ranging between 30 and 50 percent. The quartz grains are equant to elongate and rounded to angular in outline. In thin 
section many have wavy extinction or strain shadows, lines or patches of pits, or dustlike inclusions. In the thin sections of samples taken from the thick series of red beds, some of the quartz grains have silica overgrowths, but generally only on parts of the grains. These may be fragments of a quartzitic sandstone source rock. The rock fragments generally have about the same type of outline as the quartz grains but may be more rounded.

Feldspar occurs as fresh-looking albite-twinned grains with equant and angular outlines and as partly sericitized grains, some with carlsbad twinning, others with microcline twinning, and some apparently untwinned. The feldspar grains are generally finer than the larger particles of quartz, but some are coarse. Extinction on the twinned grains ranges from parallel to about $25^{\circ}$.

Muscovite or hydromica in flakes or bundles, the longest dimension of which is slightly larger than the diameter of the clastic quartz grains, forms about 1 to 10 percent of the rock. The muscovite and biotite, which makes up a few percent of some samples, are mostly oriented parallel to bedding. A black opaque mineral, probably magnetite, makes up to 1 to 3 percent of the rock. Accessory amounts of leucoxene, pale-green tourmaline, and colorless to yellow zircon occur in most of the sections. Epidote, pyroxene, hornblende, sphene, garnet, rutile, and a mineral with a blue birefringence resembling idocrase are other accessory minerals. Grains of clastic calcite or a similar carbonate occur in several samples, and most of the rocks have a calcite cement.

Sericite and small amounts of vermicular chlorite are the matrix minerals and range from about 1 to 40 percent of the rock, but make up between 15 and 20 percent of most of the samples. Dark-red to brownish-red particles of iron oxide are scattered through the matrix and give the rock its dark-red color.

X-ray spectrometer analyses of the clay-size fraction of samples of the red rocks of the Mauch Chunk formation show that quartz, chlorite, illite, $\mathrm{Fe}_{2} \mathrm{O}_{3}$, and calcite are the major components.

The Mauch Chunk-Pottsville transition zone has a basal bed about 70 feet thick that consists of gray sandstone and quartz pebble conglomerate, both of which have a dark-gray to black matrix; this rock is uraniferous on the north limb of the syncline at Mount Pisgah. Brownish-gray sandstone lenses at the base grade upward into gray sandstone. The basal bed is overlain by thin beds of red and brownish-gray siltstone and shale. The remainder of the transition zone is a series of red and gray sandstone, siltstone, and conglomerate, with about equal amounts of red and nonred beds.

The rock in the basal unit of the Mauch Chunk-Pottsville transition zone resembles the conglomerate and sandstone of the Pottsville 
formation. Samples of uraniferous and barren rock from the unit that were examined by the authors both megascopically and under the petrographic microscope include common or low-rank graywacke and feldspathic graywacke. Montgomery (1954, p. 108) describes some of the rock as arkose.

Quartz ranges from about 25 to 40 percent of the rock. The quartz grains are equant to elongate, well rounded to angular, and irregular, in outline. Most of the grains are equant and subangular. The roundness of the grains increases roughly with grain size, and the coarse pebbles are mostly well rounded. Variations in the appearance of the quartz grains in thin section, which suggest several sources of the sediments, are: wavy extinction and strain shadows, needlelike inclusions, lines or patches of pits or dustlike inclusions, crystal faces, euhedral crystal cross sections, rounded and angular outlines, and irregular edges.

Rock fragments are the next most abundant of the granular materials. Quartzitic rocks are the most abundant of these, but chert, sericitic schist, slate, shale, and siltstone, sandy limestone, and serpentine are other varieties. Rock fragments exceed quartz grains in abundance in a few thin sections of coarse-grained rock. Many of the quartzitic rock fragments are well rounded but have pieces broken off leaving part of the perimeter with angular outline. The outlines of many of the smaller rock fragments are in part angular and in part well rounded, indicating that they are broken from larger well-rounded grains.

Feldspar is more abundant in the rocks of the transition zone than in any of the older rocks of the project area. Twinned feldspar grains, some fresh looking and others greatly sericitized, occur in almost all the samples, but vary greatly in abundance. In some rocks feldspar is sparse or absent, although patches of sericitized material may be remnants of altered feldspar grains. As much as 17 percent of one sample was determined by point count to be feldspar. Montgomery (1954, p. 108) reports as much as 20 percent of feldspar. The coarser grained rocks appear to contain less feldspar and more rock fragments. Albite, carlsbad, and microcline twinning were noted in the feldspar. Maximum extinction angles of the albite-twinned feldspar are about $25^{\circ}$. Many of the albite-twinned grains have angular outlines, and they are generally less altered than the others. Some large feldspar grains are subrounded, but most are subangular.

Muscovite occurs in large flakes, some about a quarter of an inch in diameter, but these are sparse. It also occurs in smaller flakes, and muscovite or hydromica in small bundles of curved plates make up a few percent of some samples. 
Sericite ranges from a few percent to about 15 percent of the rock in many samples; it is less abundant in the coarser grained rocks. Some of the sericite is in irregular matted patches as a matrix material, but it also occurs in altered feldspar and in rock fragments.

Chlorite is common in the uraniferous rock. It is generally less than 3 percent of the sandstone and conglomerate, but is more abundant in the finer grained rocks.

The minor or accessory minerals in the rocks of the transition zone are about the same as those of the main body of the Mauch Chunk formation. Fragments and grains of calcite, epidote, hornblende, pyroxene, sphene, colorless to yellowish-brown zircon, green tourmaline, biotite, apatite, leucoxene, ilmenite or magnetite, and traces of pyrite were noted. Montgomery (1954, p. 108) reported garnet and olivine in addition to the above-mentioned minerals.

Calcite cements the uraniferous rock, and in some samples the calcite forms a matrix that separates the clastic grains. Calcite also forms late veinlets in fractures.

Silica overgrowths occur on some quartz grains and some of the barren rock adjoining the uraniferous rock is cemented by silica and by a sericite chlorite matrix. Quartz fills fractures and occurs on slickensided joint or fracture surfaces.

Black opaque matter that is probably finely ground carbonaceous material occurs in the matrix of the rock and makes it dark gray to black and distinctive in appearance.

The clay-size fraction was analyzed by $\mathrm{X}$-ray spectrometer and found to consist of quartz, chlorite, illite, calcite, and $\mathrm{Fe}_{2} \mathrm{O}_{3}$.

The occurrence of uranium in rocks of the transition zone at Mount Pisgah is described on pages 84-85.

\section{Distribution}

The Mauch Chunk formation occurs in the synclines at Jim Thorpe and at Penn Haven Junction and in the synclinal area between Rockport and Leslie Run. The complete section of the Mauch Chunk including the transition zone is limited to part of the syncline west and south of the Lehigh River near Jim Thorpe. The basal bed of the transition zone in the trough of the syncline crops out along the railroad west of the river, and the transition zone outcrop area is on the end and flanks of Mount Pisgah. The main body of red beds underlies the valleys on either side of Mount Pisgah.

A narrow band of the lower part of the Mauch Chunk formation extends in a syncline to the Lehigh River just north of Penn Haven Junction. Black Creek has incised a deep valley on the south side of the axis of the syncline where the creek flows into the river.

The lower part of the main body of red beds in the Mauch Chunk formation underlies the area between Rockport and Leslie Run and 
extends northeastward on the north side of Mud Run. There probably is not more than 500 feet of the lower part of the Mauch Chunk preserved in this area. The thick pinkish-gray sandy limestone or limy sandstone layers are exposed on the west side of the Lehigh River in cliffs above the railroad tracks. Huge boulders of these calcareous rocks broken from the cliffs can be found along the base of the cliffs. The purplish-red shaly layer at the base of the Mauch Chunk can be seen near Rockport and along the north side of Mud Run near the northern edge of the Lehighton quadrangle. Traces of malachite occur in this layer near Mud Run and just north of Penn Haven Junction.

\section{PENNS YLVANIAN SYSTEM}

\section{POTTSVILLE FORMATION}

The Pottsville formation of Pennsylvanian age overlies the Mauch Chunk formation and underlies younger unnamed rocks. A generalized description of the Pottsville and post-Pottsville rocks in the mapped area is given in table 7. The base of the Pottsville is at the top of the uppermost red bed of the Mauch Chunk-Pottsville transition zone and the top of the formation is at the base of the lowermost thick coal bed.

Smith (1895, p. 371) assigned a thickness of 1,155 feet to the Pottsville formation based on measurements at a tunnel near Nesquehoning, about 4 miles west of the project area. In another section of the Pottsville, however, he included about 300 feet of red and gray beds of the underlying transition zone in a section 1,130 feet thick.

TABle 7.-Generalized description of the Pottsville formation of Early Pennsylvanian age and the post-Pottsville rocks on Mount Pisgah near Jim Thorpe, Carbon County, Pa.

\begin{tabular}{c|c|c|c|c}
\hline \multicolumn{1}{c|}{ Rock type } & Color & Remarks & \multicolumn{2}{|c|}{$\begin{array}{c}\text { Thickness } \\
\text { (in feet) }\end{array}$} \\
\hline $\begin{array}{c}\text { Post-Pottsville rocks: } \\
\text { Sandstone, siltstone, } \\
\text { conglomerate, anthracite } \\
\text { coal, underclay. }\end{array}$ & $\begin{array}{c}\text { Gray, brownish-gray, } \\
\text { black. }\end{array}$ & $\begin{array}{c}\text { Unit } \\
\text { Mostly concealed, except in } \\
\text { strip mine pits; base of } \\
\text { post-Pottsville rocks at } \\
\text { base of lowest thick coal } \\
\text { bed. }\end{array}$ & $75+$ & $75+$ \\
\hline $\begin{array}{c}\text { Pottsville formation, Lower } \\
\text { Pennsylvanian: } \\
\text { Coarse quartz pebble } \\
\text { conglomerate, sandstone, } \\
\text { shale, thin layers or part- } \\
\text { ings of anthracite coal. }\end{array}$ & Gray, black & $\begin{array}{c}\text { Poorly exposed in project } \\
\text { area, thick conglomerate } \\
\text { beds at crest of ridges. }\end{array}$ & $900 \pm$ & $900 \pm$ \\
\hline
\end{tabular}

The top of the Pottsville section is located approximately at a strip-mine pit near the north edge of the top of Mount Pisgah at the western edge of the project area. This is about 1,200 feet south- 
southeast of the approximate location of the top of the Mauch Chunk and would allow a thickness of about 1,000 feet, if calculated on the basis of an averge dip of about $45^{\circ}$. The underlying beds have an average dip of about $40^{\circ}$. On the south edge of Mount Pisgah, however, if the top of the Pottsville is drawn through the stripmine pits, as shown on plate 1 , the base of the Pottsville is only about 600 feet to the south. The beds are vertical to slightly overturned, thus the thickness of the section would be about 600 feet. Smith (1895), in the previously mentioned section, describes a thin coal bed about 200 feet below the top of the Pottsville. If this bed is the one worked in the strip-mine pits at the south edge of Mount Pisgah, then the inferred contact as drawn may be misplaced and the section may be about 800 feet thick.

\section{Composition}

Only the conglomeratic beds and some medium- to coarse-grained micaceous sandstone of the Pottsville are exposed in the project area, but a few samples of rock were obtained, and some observations were made of the lithology of the beds in areas to the west.

The rocks of the Pottsville formation are low-rank graywacke, mostly conglomerate and coarse-grained sandstone, with interlayered thin beds of siltstone, dark-gray shale, and thin layers of anthracite. Quartz and quartzitic rock fragments are the most abundant granular materials, but also fragments of phyllite, siltstone, and chert are present in minor amounts. No twinned feldspar was noted in thin sections; however, small amounts of sericite occur in what may be relict grains of feldspar. The granular materials are poorly sorted. The coarse grains and pebbles are generally well rounded, but the sand-size materials range from well rounded to angular and from equant to elongate in outline.

Quartz is more abundant than rock fragments in some samples and less abundant in others. It ranges from about 18 to 35 percent of the rock and varies from pebbles more than 2 inches in diameter to siltor clay-size particles. The quartz grains have wavy extinction or strain shadows; some grains have needle-shaped inclusions; others have dustlike pits or inclusions; and some have silica overgrowths.

The quartzitic rock fragments have about the same range of shapes as the quartz grains, but some are much larger and in places cobbles of quartzite and cherty rock are in conglomerate. A few individual grains of quartzite are elongate and have the appearance of stretched grains.

Thin sections of a few pebbles of vein quartz and quartzitic sandstone from conglomerate of the Pottsville were examined. The quartzitic sandstone pebbles have subrounded quartz grains and are cemented with silica and minor amounts of sericite. The accessory 
and trace constituents of the pebbles are zircon in colorless to dirty yellow-brown grains with rounded to subangular outlines, green tourmaline, muscovite, biotite, small amounts of black opaque irregularshaped and possibly carbonaceous material, and a very fine grained birefringent material that may be a carbonate cement. Some pebbles are lightly stained with limonite. The phyllite, siltstone, and shaly rock fragments are well rounded, but some are broken and are therefore partly angular.

Sericite is the most abundant matrix material. It makes up about 25 to 35 percent of some of the samples, but in the conglomerate it is less abundant. Sericite occurs in patches resembling relict grains in sericitic and quartzose rock fragments, but mostly in an irregular matted mixture with small quartz fragments and accessory minerals interstitial to the coarser quartz grains and rock fragments.

Muscovite or hydromica forms about 2 to 5 percent of some of the sandstone and is generally abundant on bedding-plane partings in sandstone with a dark carbonaceous material coloring the matrix. Similar concentrations of mica flakes occur in uraniferous rock in the Catskill formation and in the Mauch Chunk-Pottsville transition zone. The mica flakes are warped by the more equidimensional clastic grains. The uniformity of size and the euhedral or subhedral shape of the mica grains may be due to mechanical sorting of sedimentary mica, but there is a possibility that these are either grains of authigenic mica or mica which has undergone diagenetic changes. The granular detrital minerals in many of these rocks are poorly sorted and have undergone partial rounding in the process of transport and deposition.

Chlorite makes up a few percent of the rock. It occurs as an irregular matrix material and in small flakes with a bluish interference color.

Zircon, tourmaline, black carbonaceous material, and limonite are accessory and trace constituents of the rock. The zircon and tourmaline are similar to that in the pebbles described previously.

Calcite in small amounts is a cementing material in some of the rock.

\section{Distribution}

The Pottsville formation in the project area underlies the upper part of Mount Pisgah and the conglomerate beds crop out along the edges of the ridges extending southwestward beyond the western edge of the area.

\section{POST-POTTSVILLE ROCKS}

The youngest rocks in the project area are unnamed beds of postPottsville rocks, of Pennsylvanian age, that crop out in the synclinal basin on Mount Pisgah and are roughly delimited by strip-mine pits or test pits. Their base is at the lowest minable coal bed, which is 
probably the "B" bed referred to by Smith $(1895$, p. 2088) and reported to be about 12 feet thick with about 9 feet of coal in workings at the Hacklebarney tunnel, a short distance west of the project area on the south side of Mount Pisgah.

A section of beds totaling about 75 feet in thickness is exposed in strip-mine pits near the western edge of the project area. At the base of the section is gray sandstone, and above this a bed of anthracite about 5 feet thick is overlain by gray siltstone. About 20 feet of beds are concealed, but these are probably gray sandstone. On top of this is 5 feet of very coarse grained sandstone, 6 feet of coal and underclay, 4 feet of gray siltstone or underclay with a 6 -inch thick parting of coal, then about 7 feet of black siltstone overlain by gray coarse sandstone 10 feet thick, 4 feet of black siltstone, and above this 15 feet of gray coarse sandstone. The thicknesses given above are approximate, because the dip of the beds is variable and the section is based on observations in two separate pits.

A long ridge of coarse conglomerate, similar to some of the beds of the Pottsville formation, crops out in the middle of the area mapped as post-Pottsville rocks. Whether this is conglomerate of the Pottsville is unknowu, but the formations are known to be highly contorted in the interior of the coal basin to the southwest of the project area. There are few good exposures of bedrock of the post-Pottsville rocks in areas that have not been exposed by strip mining. The limited exposure of this formation near the edge of the project area was examined only briefly.

\section{UNCONSOIDATED PLEISTOCENE AND RECENT SURFICIAL MATERIAL}

The locations of strike and dip symbols on plate 1 indicate places where bedrock is well exposed. In most of the intervening areas, bedrock is concealed by unconsolidated surficial material or by a thin residual mantle of broken and disoriented pieces of the bedrock.

Glacial, colluvial and alluvial debris, and soil are relatively thick in some local low areas. Because much of the area is thickly forested and a mulch of dead leaves cover the surface, it is difficult to tell where the residual mantle of broken bedrock grades into a surficial cover of glacial till and soil. Mapping on the basis of float material may be done wivh confidence in some areas but is impractical in others.

North of Meckesville, near the border of the Lehighton quadrangle, a well was dug about 50 feet through surficial material to bedrock. Another well about half a mile south of Meckesville was reported to be 26 feet deep to bedrock, and others in that area were 20 to 30 feet, according to local residents. About 2 miles to the south, bedrock crops out on Stony Ridge and Pohopoco Mountain. 
Test drilling and excavations along the northeastern extension of the Pennsylvania Turnpike reveal a mantle of clay, sand, and gravel as much as 40 feet deep in some places about a mile to the north of the quadrangle. The sediments probably are part of the Wisconsin glacial till. Highway drainage ditches in the central part of the mapped area exposed a mantle of soil and glacial till about 15 feet deep. This glacial material and that to the south are considered to be from the Jerseyan or Illinoian glacial stages. Between Call Mountain and Pohopoco Mountain, a mantle of soil and glacial till about 12 feet thick has been dug for fill in construction of a reservoir.

A mantle of soil and alluvium from a few inches to as much as 12 feet thick covers much of the more level terrain in the southern part of the area. Erratic glacial boulders and cobbles of sandstone and conglomerate from rock formations that crop out a few miles to the north are common, particularly in stream valleys.

In parts of the uplands where there is little or no soil, such as on Broad and Scrub Mountains and on the north side of Pocono Mountain, many of the topographic depressions contain large subrounded to rounded erratic boulders of quartzitic sandstone, in addition to angular boulders and cobbles of the outcropping bedrock. Small streams flow beneath these boulder fills in the valleys of the south branch of Little Bear Creek and the north fork of Hell Creek. A small boulder field extending on both sides of Route 903 east of Millstone Mountain near the north edge of the area is composed of rock from a formation that crops out on the hill northeast of the swamp at the head of Panther Creek.

Gravel bars and talus piles at the bases of steep slide areas occur along the Lehigh River and along some of the streams that drain the upland areas. Heavy 'spring runoff and occasional floods, however, scour the narrow stream valleys of finer grained sediments; so there are no extensive deposits along these streams.

\section{STRUCTURE}

The major structural features of the northern part of the Lehighton quadrangle and adjoining areas are the tight folds of the Valley and Ridge province and the contrasting gentle folds of the Pocono Plateau. The tight folds occupy most of the project area. They flank the Pocono Plateau in the central and eastern part of the project area; and folds extend into the plateau in the north-central part but become less pronounced. Cleavage and bedding-plane slippage or faulting, discussed in a later section, were important mechanisms for compensation of stresses during folding. Joint sets are well developed and are believed to have influenced the development of the present drainage pattern. 


\section{FOLDS}

The major folds that cross the project area will be discussed from southeast to northwest. See plate 1 for the locations.

\section{SYNCLINE NEAR JONESVILLE}

The axis of a broad shallow syncline trends northeastward near Jonesville and Greenzweig School in the southeastern corner of the project area. The Trimmers Rock sandstone and the Walcksville member of the Catskill formation are exposed in this area. A small part of the Beaverdam Run member of the Catskill may crop out in the center of the syncline, but this has not been determined definitely. Some nonred beds with marine fossils in this area may be interbedded with, or may immediately overlie nonfossilferous red beds of the Walcksville member, but the relations need further study. Good exposures of bedrock are rather sparse. The red beds exposed along the northeastern extension of the Pennsylvania Turnpike near Parryville (Willard, 1957, p. 2304), south of the project area, may furnish further information about the stratigraphic relations of the red beds of the Walcksville member and the nonred fossilferous beds of the Trimmers Rock sandstone near Stemlersville.

\section{LEHIGHTON ANTICLINE}

The Lehighton anticline, in the southeastern part of the area, has been eroded down into rocks of the Marcellus and Hamilton formations which are deeply incised by Wild Creek. The anticline has been cut more deeply by the Lehigh River at Lehighton, which is just south of the project area near Jamestown (pl. 1). The fold is asymmetrical; its south limb dips about $30^{\circ}$ southeast near Wild Creek; its north limb dips about $72^{\circ}$ to the northwest near the Wild Creek reservoir. Near Walcksville the north limb is overturned and dips about $75^{\circ}$ to $85^{\circ}$ to the southeast, but near Jamestown it dips steeply to the northwest. The anticline trends approximately N. $65^{\circ} \mathrm{E}$. and is paralleled by adjoining folds.

There may be some drag folding in the Marcellus and Hamilton rocks, but such folds are difficult to identify because of the lack of satisfactory exposures in which the attitude of the bedding can be determined. Drag folds in the Beaverdam Run member of the Catskill formation on the north limb of the Lehighton anticline are exposed near Walcksville and near the Lehigh River north of Jamestown. Small drag folds with an amplitude of about 8 feet and longitudinal thrust and gravity faults with as much as 6 feet of measurable displacement occur in the Trimmers Rock sandstone on the south limb of the Lehighton anticline just south of the project area in new roadcuts along U.S. Route 209. Similar folds and faults may be expected on the south flank of the anticline within the mapped area. 
Closely spaced flow cleavage in beds of the Marcellus and the Hamilton and in the Trimmers Rock dips to the southeast and ranges from about $30^{\circ}$ to vertical. Some of the beds have slaty cleavage and were quarried for slate; but in many places a second set of cleavage planes at a small angle to the major well-developed set produces a rhombic or bladed fracture pattern and the rock breaks in slivers rather than in flat slabs. Cleavage planes are generally not well developed in the silty beds of the bioherms in the Marcellus and Hamilton formations.

Steeply dipping joint sets transverse and parallel to major folds cut the beds; locally, some joints are horizontal. On the south limb of the anticline, in places where the cleavage planes parallel bedding and closely spaced joints are well developed in thin sandy and silty beds, the rocks fracture into thin elongate parallelepipeds. Some of the joint surfaces are encrusted with quartz.

Tension fractures filled with quartz and siderite occur on both limbs of the anticline near Walcksville and Wild Creek and near Big Creek. Trace amounts of pyrite and chalcopyrite occur in these fractures in several places. Near Walcksville, galena, sphalerite, pyrite, and chalcopyrite occur both in tension fractures and in thin quartz veinlets along bedding-plane surfaces.

\section{MOUNT PISGaH-CaLL MoUNTAIN SYNCLINE}

This syncline is the eastward extension of the Panther Valley syncline of the Southern anthracite field. Its axis trends approximately N. $67^{\circ}$ E. from Mount Pisgah to Call Mountain and on through Dottersville. The plunge of the syncline between Call Mountain and Mount Pisgah is about $12^{\circ}$ to the southwest. The top of the Mauch Chunk crops out at about 1,000 feet above sea level on Mount Pisgah, and the base of the Honesdale, which is about 6,000 feet lower stratigraphically, crops out about 1,300 feet above sea level on Call Mountain, nearly 10 miles northeast of Mount Pisgah.

The south limb of the syncline is locally overturned and is nearly vertical or dips steeply to the northwest over long distances, but to the northeast the dips become more gentle. The beds of the Trimmers Rock sandstone and the lower members of the Catskill formation that are overturned near Walcksville and dip about $72^{\circ} \mathrm{NW}$. near Wild Creek have dips less than $50^{\circ} \mathrm{NW}$. along Little Creek north of Kresgeville.

The north limb of the Mount Pisgah-Call Mountain syncline dips about $30^{\circ}$ or less to the southeast, with more gentle dips as each successive lower unit spoons out along the axis of the syncline. At the site of the new reservoir on Wild Creek at the base of Call Mountain, the beds in the trough of the syncline dip gently. About 
half a mile north of Dottersville, the beds dip about $38^{\circ} \mathrm{SW}$.; but the beds are flat in the area about $1 \frac{11}{4}$ miles farther to the east.

\section{UPPER WILD CREEK-JONAS ANTICLINE}

A poorly defined anticline trends from the upper part of Widd Creek, through Jonas, and along the foot of the Pocono Plateau escarpment. There are only a few dip measurements available on which to base this interpretation. Dips of about $5^{\circ} \mathrm{SE}$. at the head of Cross Run and $38^{\circ} \mathrm{SE}$. on the north side of Dottersville contrast with dips of $15^{\circ}$ to $32^{\circ} \mathrm{NW}$. along Pohopoco Mountain. Bedrock is not exposed along the center of the anticline.

\section{BROAD MOUNTAIN ANTICLINE}

The Broad Mountain anticline (sec. $B-B^{\prime}$, pl. 1) extends westward from the western part of the mapped area and is expressed topographically as Scrub Mountain. The anticline has a few minor flexures on the top, and dips are only slightly steeper on its north limb than on its south limb.

The Pocono formation extends across the Broad Mountain anticline, except in the area along the Lehigh River and to the east along Bear Creek, where the Cherry Ridge redbed member of the Catskill formation is exposed. The dip of the upper part of the Pocono along the Lehigh River west of East Mauch Chunk (Jim Thorpe) is a little less than $30^{\circ} \mathrm{SE}$. Near Penn Haven Junction and a short distance to the west along Black Creek, the upper beds of the Pocono dip $34^{\circ}$ to $39^{\circ} \mathrm{NW}$.

A broad shallow syncline on the top of Broad Mountain at the headwaters of the first creek on the west side of the Lehigh River north of Bear Creek is a minor flexure within the Broad Mountain anticline. The south limb dips about $10^{\circ}$ to $14^{\circ} \mathrm{N}$. and the north limb dips about $5^{\circ}$ to $16^{\circ} \mathrm{S}$. Exposures of bedrock suitable for measurement of dips are sparse, and other minor folds in the Broad Mountain anticline may be concealed.

Small distinct anticlinal folds within the Broad Mountain anticline are exposed in the Catskill formation in the valley of the Lehigh River, near Penn Haven Junction, south of Butcher Hollow, and near Bear Creek. Uranium occurs in the folds near Penn Haven Junction and Butcher Hollow.

\section{STONY CREEK SYNCLINE}

A narrow syncline parallels the north side of the Broad Mountain anticline. Its axis is about 1,000 feet north of Black creek, where it extends along the Lehigh River to Stony Creek and continues northeastward between Christman and Stony Creek School. Most of the syncline is underlain by the upper member of the Pocono, but a narrow $675114-63-5$ 
belt of the Mauch Chunk formation is preserved att he Lehigh River and widens west of the river.

\section{BALD MOUNTAIN-UNIONVILLE ANTICLINE}

A narrow anticline extends from the western edge of the project area along Bald Mountain and the ridge at Unionville to Millstone Mountain. The anticline is capped by the Pocono formation, but an inlier of Catskill is exposed along the Lehigh River west of Unionville. Dips on the south limb of this anticline are about $33^{\circ}$ to $50^{\circ}$, and on the north limb are $14^{\circ}$ to $25^{\circ}$.

Two small anticlinal folds in the beds of the Catskill formation, similar to those containing the uranium occurrences south of Penn Haven Junction, are exposed at railroad-track level along the Lehigh River between Stony Creek and Drakes Creek, but no radioactive rock was found at either locality. Small thrust faults occur at each of the minor anticlines. The updip continuation of these faults cannot be traced very far on the steep slope. They probably merge with bedding-plane slip surfaces.

\section{DRAKES CREEK SYNCLINE}

On the north side of the Bald Mountain-Unionville anticline, a narrow syncline extends from the western edge of the project area, northeastward to Panther Creek and perhaps to Keipers Run, near the northern edge of the mapped area. The syncline plunges about $2^{\circ} \mathrm{SW}$.

The base of the Pocono crops out at about 1,600 feet above sea level near Panther Creek, and the base of the Mauch Chunk crops out about 1,100 feet above sea level on the north side of Bald Mountain, about $51 / 2$ miles to the west of Panther Creek. Assuming a thickness of about 550 feet for the Pocono, its base would be about 550 feet above sea level at Bald Mountain, and the plunge would be about 200 feet per mile.

\section{SUMMER MOUNTAIN ANTICLINE}

The Summer Mountain anticline is a narrow fold that extends for about 6 miles from Panther Creek to the narrow neck of the ridge about 1 mile east of the Rockport bend in the Lehigh River. Dips on the north limb range from about $24^{\circ}$ to $31^{\circ}$ and on the south limb from $9^{\circ}$ to $28^{\circ}$. There are minor flexures in the beds in the area between the railroad tunnel and Rockport. The relatively steep dips on the north limb of the anticline persist to the north edge of the project area, but the dip of the south limb becomes more gentle near Panther Creek.

\section{LARRYTOWN SYNCLINE}

A broad and relatively shallow syncline in the Larrytown Poor Farm area between Rockport and the hill north of Leslie Run extends 
northeastward to the northern edge of the project area. There are some minor undulations in the beds just west and north of the confluence of Mud Run and the Lehigh River, and in the Pocono and Mauch Chunk formations along the Lehigh River north of the project area.

\section{POCONO PLATEAU}

The area north and northeast of Stony Ridge and north of Pohopoco Mountain is a plateau. Although practically no outcrops of bedrock on which reliable dip measurements can be taken have been found in this area, the authors are reasonably certain that the beds dip gently, probably less than $15^{\circ}$. The dips are gentle in the coarse-grained red sandstone and red-matrix conglomerate of the Cherry Ridge member at Stony Ridge and in the extreme northeastern part of the mapped area as well as at several places a short distance north of the mapped area. The slope of the terrain probably reflects the dip of the bedrock. If the dips were very steep, it is likely that some of the more resistant beds would form hills large enough to protrude above the surface of the mantle of glacial till.

Mud Run, near Meckesville, is probably near a synclinal axis. The northwestward-dipping conglomerate beds on Stony Ridge and the conglomerate at Pimple Hill and Lake Mountain, which are about 5 miles to the north and a few hundred feet higher above sea level, are in the Cherry Ridge redbed member of the Catskill formation. This indicates a reversal of the dip somewhere between Stony Ridge and Lake Mountain, or a very great increase in thickness of the Cherry Ridge redbed member.

\section{RELIEF OF STRESS DURING FOLDING}

In areas where the formations are folded as tightly as in the Lehighton quadrangle, it is not unusual to find places where the stresses produced in folding caused the rocks to rupture. In the project area, major displacements of the formations are parallel to bedding, along bedding-plane slip surfaces or faults. No major faults that cross complete formations and only relatively few minor intraformational faults have been recognized in the area. Drag folds, flow cleavage, fracture cleavage, joints, tension fractures, irregular fractures, and minor faults are other features that developed in response to deformational stresses.

\section{BEDDING-PLANE SLIPPAGE, FAULTS, AND DRAG FOLDS}

During major folding of thin-bedded rocks, relatively minor slippage along individual bedding planes may produce a large combined displacement within a thick formation. In a simple fold where the beds maintain their relative positions near the axis and bedding-plane 
slippage takes place on the limbs, the amount of combined displacement at a point where the limbs are vertical is the difference in length of arcs described in a $90^{\circ}$ segment of fold by points on the top and bottom surface of the formation and is therefore a function of the thickness of the formation. The equation for this amount would be $S=\frac{\pi R}{2}$, where $R$ equals the thickness.

A thick section of beds of the Trimmers Rock sandstone and the Walcksville and Beaverdam Run members of the Catskill formation on the north limb of the Lehighton anticline, exposed along the northeastern extension of the Pennsylvania Turnpike near Walcksville, will serve as an example of the amount of displacement that could be involved, the number and spacing of bedding planes in a formation, and the average displacement on indivdual bedding planes. The beds are overturned slightly and dip steeply to the southeast. In a section 2,325 feet thick, 92 major zones of bedding-plane slippage were noted, and 18 more were inferred; this is approximately one bedding-plane slip surface for about 21 feet of beds. If the Lehighton anticline is considered to be a simple fold, the theoretical displacement between points on the top and base of the section where the beds are vertical would be $\pi \times 2,325$, or about 3,650 feet, but the displacement on individual slip surfaces would average only about 33 feet. Where the beds are overturned, displacements would be greater.

Factors such as drag folding, stretching, tension fracturing, faulting asymmetric folding, and overriding of beds make the actual amount of displacement differ from that theorized, and it is not possible to calculate the amount of movement that actually took place along individual bedding-plane surfaces. Nevertheless, there is no question that there has been such movement in the Lehighton quadrangle. The bedding-plane surfaces are commonly encrusted with quartz, and the quartz is slickensided. Many of the slickenside surfaces have sets of grooves and steps at different angles, indicating more than one period and direction of movement. Gouge zones also occur along bedding-plane surfaces. A few deeply weathered zones between beds in the Pocono formation on Bear Mountain may represent planes of major displacement. It appears on the basis of the abundance of these slickensided and gouged surfaces that the movement of beds by displacement along bedding planes is the major mechanism by which the dimemsions of the beds have been adjusted to compensate for deformational stresses.

The distribution of zones or surfaces of bedding-plane slippage and some other features of the rock formations exposed along the Lehigh River between Jamestown and Mount Pisgah are given as follows: 


\begin{tabular}{|c|c|c|c|c|}
\hline Stratigraphic interval & $\begin{array}{l}\text { Approximate } \\
\text { thickness of } \\
\text { section in feet }\end{array}$ & $\begin{array}{c}\text { Number of zones } \\
\text { or surfaces of } \\
\text { bedding-plane } \\
\text { slippage }\end{array}$ & $\mid \begin{array}{c}\text { Dip of beds } \\
\text { (degrees) }\end{array}$ & $\underbrace{\text { Number of }}_{\substack{\text { minor } \\
\text { faults }}}$ \\
\hline $\begin{array}{l}\text { Main body of red beds in } \\
\text { Mauch Chunk formation }\end{array}$ & 1.500 & & & \\
\hline Pocono formation & $\begin{array}{l}1,000 \\
1,100\end{array}$ & $41+$ & $\begin{array}{l}2 y-02 \\
52-84\end{array}$ & $?$ \\
\hline $\begin{array}{l}\text { Cherry Ridge member of Cats- } \\
\text { kill formation }\end{array}$ & 950 & 33 & $70-84$ & 1 \\
\hline $\begin{array}{l}\text { Honesdale and Damascus mem- } \\
\text { bers of Catskill formation, } \\
\text { combined }\end{array}$ & 5,000 & $65+$ & $60-90$ & 4 \\
\hline $\begin{array}{l}\text { Beaverdam Run member, } \\
\text { Walcksville sandstone mem- } \\
\text { ber of Catskill formation, and }\end{array}$ & & & & \\
\hline $\begin{array}{l}\text { Trimmers Rock sandstone } \\
\text { combined }\end{array}$ & 3,000 & $20+$ & $67-90$ & 2 \\
\hline
\end{tabular}

Additional bedding-plane slip surfaces probably exist in the concealed intervals in the section; so the numbers listed for the various formations are minimums rather than totals. There are probably a great many more concealed slip zones in rocks of the lower part of this section, which are relatively thin bedded, than in the Mauch Chunk formation, which is better exposed and which has massive beds more than 100 feet thick between some bedding-plane slip surfaces. Suitable sections of the transition zone between the Mauch Chunk formation and younger rocks and of beds of the Marcellus and the Hamilton are not exposed, and the distribution of bedding-plane. slip surfaces could not be determined in these units. Bedding-plane slip surfaces are not well developed in rocks of the Marcellus and Hamilton formations where they are exposed; a probable explonation of the reason for this is given in the section on cleavage.

Examples of bedding-plane slip surfaces, faults, joints, and fractures are illustrated by sketches in figure $2 A$. The fault shown in figure $2 B$ has a net slip of about 50 feet and a throw of about 25 feet. The south side moved upward relative to the north side, and a large vector of this movement is in the direction of bedding-plane slippage on the south limb of the Bald Mountain anticline. The amount of displacement indicates the order of magnitude of bedding-plane slippage in some of the unfaulted beds on the limbs of folds.

About 650 feet north of the fault shown in figure $2 B$ another thrust fault, but one with only about 3 feet of displacement, occurs on the north limb of a minor anticline. The movement on this fault is also in the same direction as movement on the bedding-plane slip surfaces. The faults cannot be traced very far and it is likely that they merge with bedding-plane slip surfaces or terminate in shaly beds interlayered with beds of sandstone. The fault shown in figure $2 B$ may extend across the Lehigh River to the minor anticline exposed west of the 


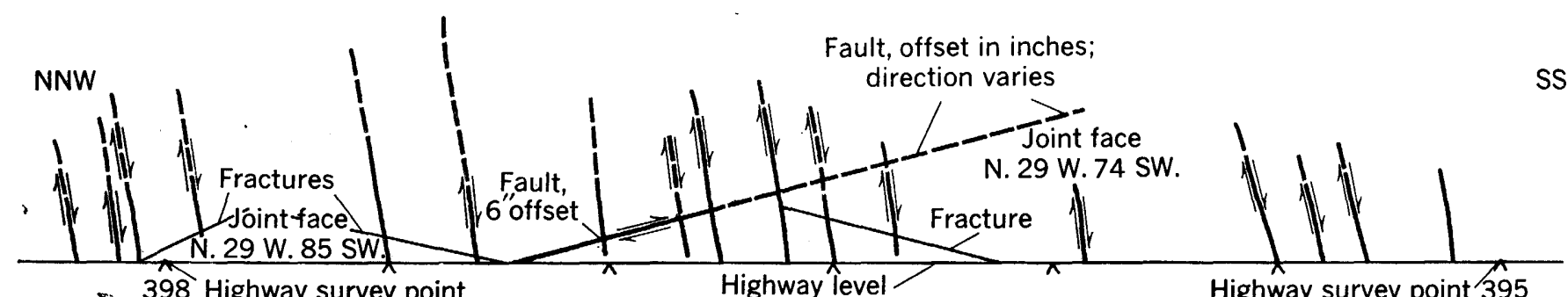

- 398 Highway survey point

Highway level

Highway survey point 395

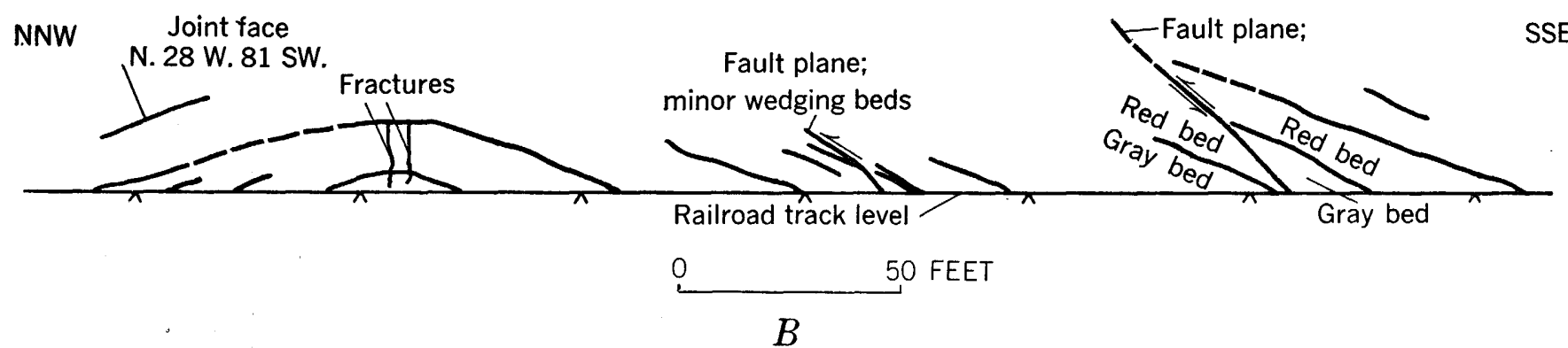

Figure 2.- $A$, Sketch of bedding-plane slip surfaces, minor faults, joints, and fractures on the east face of a roadcut along the northeastern extension of the Pennsylvania Turnpike near Walcksville, Carbon County, $\mathrm{Pa}$; and $B$, Sketch of faulted minor fold in the Bald Mountain-Unionville anticline exposed on the east side of Lehigh River along Lehigh Valley Railroad near Unionville, Carbon County, Pa. 
river, for the rocks there are fractured, but the amount, if any, of displacement there has not been determined.

Drag folding, another feature that indicates relative direction of movement and gives some measure of the minimum amount of movement, is well exposed in beds of the Beaverdam Run member along the Lehigh River.

\section{Cleavage}

Flow cleavage and fracture cleavage are well developed in the finegrained rocks of some of the formations in the project area. In almost all the Marcellus and Hamilton rocks flow cleavage or slaty cleavage is well developed, and in places it is so closely spaced that the rock is slate. The cleavage in these rocks on the north side of the axis of the Lehighton anticline dips about $40^{\circ}$ to $60^{\circ}$ S.E. Near the center of the Hamilton outcrop area the cleavage generally dips $50^{\circ}$ to $74^{\circ} \mathrm{SE}$., but locally along Wild Creek a cleavage set dips from $81^{\circ}$ to vertical. Near Pohopoco Creek the dip of the cleavage becomes more gentle, and dips as low as $24^{\circ}$ S.E. have been observed. The dip of the cleavage is approximately parallel to the dip of the bedding near the base of the Trimmers Rock sandstone south of Pohopoco Creek.

Thin beds of shale and siltstone in most of the younger formations have well-developed fracture cleavage which dips at a steep angle to the bedding. The fracture cleavage is inclined so that the acute angles between the cleavage planes in the shale and bedding planes between the shale and adjoining rocks point in the general direction of relative movement of the adjoining beds.

The contrast between the effects of structural deformation in the Marcellus and Hamilton formations and those in the younger formations is worthy of further discussion. No evidence that the Marcellus and the Hamilton have undergone any separate period of major deformation that did not also involve the younger formations has been recognized by the authors. Therefore, it appears that the development of flow cleavage in the Marcellus and the Hamilton and of bedding-plane slip surfaces and fracture cleavage in the younger rocks are related phenomena.

The explanation for the extensive development of flow cleavage in the Marcellus and the Hamilton and for the only minor development of cleavage in the younger formation may be found in the character of the rocks. The Marcellus and the Hamilton are a relatively homogeneous section of fine-grained rock that was folded contemporaneously with the more heterogeneous layers of younger rocks. The younger formations consist largely of coarser grained material with interlayered beds of fine-grained material. The flow cleavage in the Marcellus and Hamilton is superimposed on a major fold and may be considered as being, in effect, a large-scale fracture cleavage developed 
in the whole formation because the rock was so homogeneous that it reacted to folding as a thin bed of shale between massive sandstone beds would react. The direction of dip of the flow cleavage in the Marcellus and the Hamilton would therefore indicate that there was a northwestward relative movement of the overlying formations. The asymmetry of the Lehighton anticline with steep and locally overturned north limbs would tend to bear out this line of reasoning.

The thick and more competent sandstone beds of the younger formations moved as units. Their bedding-plane surfaces were principally bedding-plane fault surfaces on which gouge zones and slickensides were developed. Thin shale beds between the massive sandstone beds developed fracture cleavage inclined at a moderately high angle to bedding, and, where the movement was sufficiently great, the fracture cleavage was destroyed and a bedding-plane cleavage was developed in the shale. There was sufficient cover on most of the formations to cause seemingly brittle beds of rock to deform plastically, and even thick massive beds of coarse-grained pebbly sandstone are locally warped extensively in drag folds.

The plastic deformation of the sandstone may have involved much mechanical destruction of the matrix minerals, for the pebbles and coarse sand grains of these rocks do not appear to be stretched or deformed plastically or to have been rotated so as to aline their long axes in any preferred direction that would be contrary to their orientation when the sediments were deposited.

\section{JoINTS}

There are 2 well-developed major joint sets in the project area; 1 set trends east-northeast, the other trends north-nortbwest. Another set that trends north-northeast is not so prominent. The joint symbols on plate 1 in some areas represent a single observed joint and in other areas, such as along the Lehigh River, represent many joints along a cliff or steep bluff where the rock faces are well exposed.

The trend of the east-northeast set of joints is generally about $\mathrm{N}$. $65^{\circ} \mathrm{E}$., approximately parallel to the strike of the major folds, but it varies from about $\mathrm{N} .45^{\circ} \mathrm{E}$. to about $\mathrm{S} .85^{\circ} \mathrm{E}$. The dip of these joints in most places is between $50^{\circ}$ and vertical, but some east-northeastward-trending joints have dips as low as $11^{\circ}$. The dip of the eastnortheastward-trending joints is to the southeast in many places, but northwesterward dips also occur, and the distribution of northward- or southward-dipping joints is not restricted to any particular part of the project area.

The other set of well-developed major joints trends north-northwest, mostly about N. $25^{\circ} \mathrm{W}$. to N. $40^{\circ} \mathrm{W}$. but ranges from about N. $2^{\circ} \mathrm{W}$. to about N. $50^{\circ} \mathrm{W}$. These joints have dips of $70^{\circ}$ to $90^{\circ}$ in most places. 
A few that have much lower dips have been noted. Most of these joints dip to the southwest, but some dip northeast.

Joints that trend north-northeast and dip steeply to the northwest or southeast occur in several places in the project area. Most of these have dips between $70^{\circ}$ and vertical; a few have more gentle dips.

The major joint systems in the project area are believed by the authors, to have been developed at the end of the period of major folding, for they have fairly uniform trends despite the many different positions in which they occur with respect to other structural forms. In addition, the joint surfaces are smooth planes with no gouge zones or breccia, which might have formed if the jointed rocks had undergone further deformation.

Smooth-surfaced well-developed joints have not been noted by the authors in the Pottsville and younger rocks, but this may be due to the nature of the rocks and to poor exposures of these rocks in the project area. Large fractures or rough joints do occur in these formations and are probably part of the major joint systems.

Joints trending north-northwest and others trending northeast make prominent cliff faces and craggy outcrops on thick quartzitic beds along the steep-sided Lehigh River valley. Joint faces as much as $\mathbf{5 0}$ feet long and 30 feet high are exposed near Penn Haven Junction. Some of these joints are encrusted with quartz and large euhedral crystals of clear quartz, some 2 or 3 inches long, are found in some places. Smaller crystals, some doubly terminated and others that are elongate with one good termination, are exceptionally clear. Some have phantom crystal outlines within a euhedral crystal.

Quartz-encrusted joints are exposed at the uranium occurrence near Penn Haven Junction, and quartz crystals can be found in the weathered rock. The joints were probably opened below the zone of oxidation, because the uraninite and clausthalite in the rock have not been decomposed to form secondary minerals along the joints. The quartz that fills or partly fills the joints has not been crushed or brecciated. Either it formed very late, or the joints have remained stable for a long time.

\section{FRACTURES}

Irregular fractures in the rock formations are quite numerous and probably played an important part in relief of stresses during the folding of the rocks. Bedding-plane partings are developed on crossbedding, and fractures are developed around lenses or channels and merge with more regular bedding-plane surfaces. Some of these resemble faults, but the displacement, if any, cannot be determined. In a few places, large fractures that cross thick beds at an angle and merge with bedding-plane fractures between dissimilar beds have been noted, but the parts of the fractured beds do not appear to have been 675114-63-6 
displaced. Brecciated zones along bedding planes occur locally. These have quartz and chlorite between the rock fragments.

The conglomeratic beds generally have irregular fractures around lenticular bodies of the rock between lenses or beds of sandstone. The basal conglomerate member of the Mauch Chunk-Pottsville transition zone exhibits this feature at the uranium occurrence on Mount Pisgah.

\section{ELLIPSOIDAL STRUCTURES}

Several types of ellipsoidal structures have been noted in sandstone in the project area. One, the "storm roller" described by Willard (1957, p. 2303), consists of spheroidal masses of concentric sandy shells, some of which contain marine fossils. Examples can be seen in an outcrop of the Beaverdam Run member of the Catskill formation a few hundred feet south of Beaverdam Run, on the north-sloping hill on U.S. Route 309, north of Jamestown. Similar rolls are exposed in the Trimmers Rock sandstone near Walcksville.

Another type of ellipsodial structure that is common in the Devonian rocks may be due to concentric weathering of roughly equidimensional masses of rock between fractures, joints, and bedding planes. These rocks, when exposed in weathered outcrops, have shells of sandstone that are generally stained on the surface with a blue-black or brown iron oxide or iron and manganese oxide. The outer shells spall off readily.

Similar masses of rock, but in a preliminary stage of development, have been noted in the Pocono formation. Thick massive beds of jointed and fractured sandstone have a round central area with a concentric brown ring of iron oxide staining and with curved fractures that tend to conform, in part, to the curvature of the iron-stained zone.

Ellipsoidal structures are an important feature of the uranium occurrences at Mount Pisgah and near Penn Haven Junction, which are described in a later section (p. 77-84). Some have concentric zones of uraniferous rock. They are similar in part to the weathered concentric masses in the Devonian rocks and the partly developed ones in the Pocono.

Another ellipsoidal structure that has been noted only in a quarry in the red sandstone of the Mauch Chunk formation along U.S. Route 209, on the south side of Broad Mountain a short distance west of the project area, may help to explain the development of some of the similar structural features found in the area. Those in the Mauch Chunk formation are elongate blunt ellipsoidal bodies that lie with their long axes parallel to the strike of the beds. They are roughly round in smallest cross section and have no zones of discoloration on their peripheries. The structural features are in a single thick sandstone bed between other thick beds of sandstone. 
They vary from 3 or 4 feet in length and about 1 foot in cross section to 10 or 12 feet in length or more and 4 or 5 feet in cross section. The intervening rock is apparently the same as that in the ellipsoidal structures. Their general appearance suggests that they have developed due to folding and perhaps to a crinkling and tension fracturing of the beds parallel to the strike, and they may be an early form of boudinage-type of structural feature in sedimentary rocks.

\section{METAMORPHISM}

The rocks in the project area are well indurated and very tough. Petrographic studies show that most of the rocks have low porosity because the interstices between the granular components are filled with clayey and micaceous matrix minerals. The major components of the matrix, identified by X-ray spectrometer analysis, are illite, chlorite, and quartz in all the rock formations. The illite is a $2 \mathrm{M}$ muscovite-type mineral (Yoder and Eugster, 1955, p. 225-280). In the X-ray trace of one sample of red shale from the Damascus and in one sample of shale from the Trimmers Rock, small peaks suggestive of 1 M-type muscovite were noted in addition to the 2 M-type muscovite. The general homogeneity of the clay minerals may be due to the metamorphism of the micaceous minerals to the 2 M-type structure. The youngest rocks in the project area, which would have had the least lithostatic load, have been metamorphosed sufficiently to convert the coaly materials to anthracite. The oldest exposed rocks have been converted to slate. It appears, therefore, that the 2-Mtype muscovite and chlorite are stable mineral phases of both these grades of metamorphism.

\section{GEOLOGIC HISTORY}

A thick section of Lower Devonian and older Paleozoic rocks that crop out to the south are believed to overlie rocks of Precambrian age beneath the project area. No drilling in the project area has been deep enough to penetrate beds statigraphically lower than those that crop out; so no direct information is available about the subsurface rocks.

The oldest rocks at the surface in the northern part of the Lehighton quadrangle and adjoining areas are composed of fine-grained sediments that were deposited in a marine environment in Middle Devonian time. Bioherms of these rocks indicate that at times the waters were shallow. In the early part of the Late Devonian epoch, coarser grained sediments alternating with fine-grained sediments were deposited in marine waters. The sea retreated and arenaceous sediments on which plant life developed were deposited and formed the basal member of the Catskill formation. This offlap was followed by an onlap of the sea, and arenaceous and argillaceous sediments were 
again deposited in a marine environment. Later, possibly in Chemung time (Willard, 1939 , p. 291-300), the sea again retreated, and sediments were deposited under terrestrial conditions. The deposition of a thick section of arenaceous beds began and formed the main body of the Catskill formation of Late Devonian age.

Deposition of sediments under terrestrial conditions continued into Early Mississippian time, but the development of red sediments ceased for a while, and beds of the Pocono formation of Mississippian age were deposited as relatively coarse grained gray quartzose sediments. No intersystemic hiatus is evident between beds of Devonian and Mississippian ages in the project area. Gradational changes in sedimentation took place at the beginning of Late Mississippian time, after which the nature of the sediments and their environment of deposition changed rapidly, and a thick section of red sandy, silty, and clayey beds accumulated, with thin interlayered beds of limy sandstone and sandy limestone.

Most sediments of the continental Late Devonian and Early Mississippian rocks were derived from preexisting sedimentary and low-grade metamorphic rocks. Minerals derived from igneous or high-rank metamorphic rocks and calcareous material are more abundant in the red beds of Late Mississippian age, but probably the bulk of the sedimentary material still came from preexisting clastic sedimentary rocks. Plantlife grew on these beds, but it probably was not very abundant locally as plant fossils are not abundant. Ripple marks, mud cracks, and imprints of rain are preserved in these rocks.

After the thick section of red beds had accumulated in Late Mississippian time, the nature of the sediments changed abruptly, and a period of transition began in which coarse gray sands and gravels were deposited and plant life was more abundant locally. At intervals the accumulation of red sediments recurred. These were derived, at least in part, from preexisting red sedimentary rocks.

The final interval of accumulation of red sediments is considered to be the end of the Mississippian period. Deposition of the coarse gravels and sands that form the Pottsville formation of Pennsylvanian age began with no greater hiatus or contrast in sediments than that between red and gray beds of the Late Mississippian transition zone. Plantlife was more abundant, or at least more evidence of it remains in the carbonaceous material of the Pennsylvanian rocks than in the older rocks. Thin beds of coal accumulated between layers of coarsegrained gray rocks, and finally a period began in which thick beds of coal accumulated. These coal beds and the intervening fine- and coarse-grained gray and gray-black beds are the post-Pottsville rocks of Pennsylvanian age. They are the youngest consolidated rocks of the project area. 
Most of the sediments of the Mauch Chunk-Pottsville transition beds and of the Pottsville and post-Pottsville beds were derived from preexisting sedimentary rocks and from low-rank metamorphic rocks. These older sedimentary rocks were partly quartzitic sandstone and partly shale and siltstone. Some limestone and chert pebbles are also found. The metamorphic rocks were phyllite, slate, and sericitic schist. Vein quartz is also abundant in the sedimentary rocks. Minerals derived from igneous rocks are not known to be abundant in the Pottsville and post-Pottsville rocks.

The Devonian sediments were derived from areas to the southeast (Willard, 1939, p. 274-276). The Pocono, Mauch Chunk, and Pottsville formations also had sources to the southeast and each of these is known to thin to the northwest. The abrupt termination of thick sections of the Mississippian and Pennsylvanian rocks in the southwestern part of the project area permits only speculation about their former extent and character in areas to the east and south. Quartzitic sandstone of the older Silurian formations that crop out to the south are a possible source of the quartzose material in the younger formations, but the beds of Silurian age also terminate abruptly in thick sections, and their previous extent to the southeast is also unknown.

The fact that the coaly material in the youngest rocks of the project area and in younger Pennsylvanian rocks in adjoining areas to the west has been converted into anthracite suggests that still younger rock once covered the area. How thick a section would have been required to create conditions under which anthracite could form is not known. The coal-bearing beds in the area immediately to the west of the mapped area are known to be greatly contorted, and, unless these contortions are drag folds, it seems unlikely that they were overlain by a very thick section of rocks, or some of the younger rocks would have been infolded with the coal-bearing beds.

If the beds of Mauch Chunk, Pottsville, and post-Pottsville ages once extended over the Broad Mountain anticline, which they probably did, a section of rock more than half a mile thick has been eroded from the top of Broad Mountain. No trace of the red beds remains, but some of the coarse pebbles and other components of the younger post-Pottsville rocks could lave been derived from the Pottsville and from beds of early post-Pottsville age eroded from areas between the coal basins.

Permian rocks have not been reported in northeastern Pennsylvania. The nearest rocks younger than the Pennsylvanian are the Triassic rocks of the Piedmont province in southeastern Pennsylvania. These were derived from rocks in the area between the anthracite fields and the Piedmont province and from areas to the east or southeast (Mc- 
Laughlin, 1944, p. 62-69). It thus appears unlikely that rocks of Triassic age were deposited above the Pennsylvanian rocks in the project area.

Downwarping of the area of deposition relative to the source area of the sediments was probably a fairly continuous process, and there appears to have been no major hiatus between Middle Devonian and Pennsylvanian time in the project area. The conformity of the formations up through the post-Pottsville rocks indicates that intense folding occurred in Pennsylvanian time or later. The development of cleavage in beds of the Marcellus and Hamilton formations and jointing in all the formations probably took place near the end of the period of intense folding. The jointing probably is post-Pennsylvanian and may be Triassic or younger. Well-developed joint sets with similar trends occur in Triassic rocks in southeastern Pennsylvania (Avery Drake, oral communication, 1958).

The regional drainage pattern furnishes some information about the post-Pennsylvanian history of the project area. The course of the Lehigh River is generally across the strike of the ridges, and long stretches of the river parallel the north-northwesterly set of joints and the north-northeasterly set of joints. Most major bends in the course of the river follow large structural features.

Younger rocks that may have overlain the project area could have been left in the valleys after the area was eroded to a general peneplain or rough base level and thus influenced the direction of flow of the river across the major structural features. The trends of joint structures and the trend of beds of less resistant rocks around major structural features are believed by the authors to have been more important factors in determining the course of the river.

It is interesting that the present major drainage pattern is directed to a low area in the general direction from which the sediments that make up the rocks in the project area came; thus, the relative topographic positions of these areas were reversed between Pennsylvanian and Pleistocene time.

The effects of glaciation in Pleistocene and Recent times are evident in the form of glacial till, rejuvenated streams, and relatively soilless high areas. The lithostatic load imposed by the ice sheets may have caused some minor depression of the rock strata, and a readjustment for the loss of this pressure may have caused a slight rise in the strata. The quartz-encrusted slickenside surfaces with more than one set of slickensides may be evidence of adjustment to the loading and unloading of glaciers on the rock strata or to minor tectonic deformation. 


\section{PALEONTOLOGY}

Marine fossils occur in great variety and abundance in some beds of the Marcellus and Hamilton formations of Middle Devonian age, and in lesser variety in rocks of the Susquehanna group of Late Devonian age, in the Lehighton quadrangle area. Collections of fossils from various localities in the area were made by the authors and identified by G. A. Cooper, of the U.S. National Museum. The fossils and the localities in which they were found are listed in table 8 and the sample sites are located on plate 1 . The fossils in table 8 are merely a few of the many different types that occur at these places. Localities 35,51 , and 90 are excellent fossil-collecting sites, where many specimens of a great number of different fossils with well-preserved detailed markings may be obtained.

Most of the fossils are Marcellus and Hamilton types, which occur through a wide stratigraphic range. A brachiopod considered to be an index fossil of the Tully formation at the top of the Middle Devonian or at the base of the Upper Devonian, as discussed in the section on stratigraphy, has been found in two places: at localities $26 \mathrm{~A}$ and 44 (pl. 1). These two places are near the position at which the contact between the Marcellus and the Hamilton and the Susquehanna would be drawn, on the basis of differences in the rock types.

TABLE 8.-Devonian marine fossils from the northern part of the Lehighton, Pa., quadrangle and some adjoining areas and localities in which they occur

Rock unit: Dmh Marcellus and Hamilton formations, undivided;

Dtr Trimmers Rock sandstone of Susquehanna group

Deb Beaverdam Run member of Catskill formation of Susquehanna group.

[Fossils identified by G. A. Cooper, U.S. Natl. Mus., written communication, 1958. See locality deserip. tions at end of table]

\begin{tabular}{|c|c|c|}
\hline Name & Locality (No. on pl. 1) & Rock unit \\
\hline Actinoptera sp... & $25,51_{-}$ & Dmh, Dtr \\
\hline Ambocoelia umbonata. & $22,44,51$ & $\mathrm{Dmh}$ \\
\hline Athyris $\mathrm{sp}_{\ldots} \ldots \ldots$ & $27,28,47,51$ & Dmh \\
\hline Blastoid plate & $51 \ldots$ & $\overline{D m h}$ \\
\hline Brachyspirifer $\mathrm{sp}$ & $27,34,35,47,51,75,90$ & Dmh, Dtr \\
\hline Bryozoa & 35 & Dmh \\
\hline Camarotoechia sp & $29,51,71,76,92$ & Dmh, Dtr \\
\hline Charionella? sp. & $51-$ & Dmh \\
\hline Chonetes vicinus & $\begin{array}{l}22,24,28,34,46,47,51,71,76 \\
\quad 90 .\end{array}$ & Dmh,Dtr \\
\hline Coenites sp. & $34 \ldots$ & Dtr \\
\hline Corals & & Dtr \\
\hline Cranaena sp & $27-----$ & Dmh \\
\hline $\begin{array}{l}\text { Crinoid debris } \\
\text { Cypricardella } \mathrm{sp}\end{array}$ & $25,30,34,73,91 \ldots$ & $\begin{array}{l}\text { Dtr } \\
\text { Dmh, Dtr }\end{array}$ \\
\hline Cyrtina $\mathrm{sp}_{-}$ & $\begin{array}{l}20,28,34,46,01 \\
22,38\end{array}$ & Dmh, Dtr \\
\hline Dolatocrinus sp. & $51 \ldots$ & $\mathrm{Dmh}$ \\
\hline Douvillina sp... & $22,27,28,36,51$ & Dmh, Dtr \\
\hline Echinocoeliasp & 44 & Dmh \\
\hline $\begin{array}{l}\text { Elytha fimbriata } \\
\text { Favosites sp }\end{array}$ & $27,32,33,51,75,90$ & $\begin{array}{l}\text { Dmh } \\
\mathrm{Dmh}\end{array}$ \\
\hline
\end{tabular}


TABLE 8.-Devonian marine fossils from the northern part of the Lehighton, Pa., quadrangle and some adjoining areas and localities in which they occur-Continued

Rock unit: Dmh Marcellus and Hamilton formations, undivided;

Dtr Trimmers Rock sandstone of Susquehanna group;

Dcb Beaverdam Run member of Catskill formation of Susquehanna group.

\begin{tabular}{|c|c|c|}
\hline Name & Locality (No. on pl. 1) & Rock unit \\
\hline Favosites sp. (branchi & $33_{-}$ & Dmh \\
\hline Fenestellid bryozoan. & $51 \ldots$ & $\mathrm{Dmh}$ \\
\hline Fimbrispirifer? sp & & $\mathrm{Dmh}$ \\
\hline Gennaeocrinus sp & 27,51 & $\mathrm{Dmh}$ \\
\hline Grammysioidea $\mathrm{sp}$ & & $\mathrm{Dmh}$ \\
\hline Greenops sp & $38,51,71$ & Dmh, Dtr \\
\hline Heliophyllum sp.... & $28,32,33$ & $\mathrm{Dmh}$ \\
\hline Hypothyridina venust & $44 \ldots$ & $\mathrm{Dmh}$ \\
\hline Hyolithes sp_........ & $26 \mathrm{~A}$ & $\mathrm{Dmh}$ \\
\hline Leiorhynchus sp.... & $\begin{array}{l}22,25,26,26 \mathrm{~A}, 29,31,38,44 \\
\quad 47,71 \text {. }\end{array}$ & Dmh, Dtr \\
\hline mesacostale & 26,47 & Dmh, Dtr \\
\hline mesastriale_- & 22,7 & Dmh, Dtr \\
\hline Leiopteria sp & $46 \ldots$ & Dtr \\
\hline Longispina mucronata & 27,51 & Dmh \\
\hline Modiella pygmaea & $26 \mathrm{~A}, 73$ & Dmh, Dcb \\
\hline Modiomorpha $\mathrm{sp}$ & $51 \ldots$ & Dmh \\
\hline Mucrospirifer sp.-- & $22,24,26$ & Dmh, Dtr \\
\hline Nucleospira concinna & $22,27,36,51,75$ & Dmh, Dtr \\
\hline Nucula $\mathrm{sp} \ldots \ldots$ & $27 \ldots \ldots$ & Dmh \\
\hline varica & $47--$ & Dmh \\
\hline Palaeoneilo sp & 27,31 & Dmh \\
\hline $\begin{array}{l}\text { Paracyclas } \mathrm{sp}_{\mathrm{S}} \ldots \ldots \\
\text { Parallelodon } \mathrm{sp} .\end{array}$ & $26 \ldots$ & $\begin{array}{l}\text { Dtr } \\
\text { Dmh }\end{array}$ \\
\hline $\begin{array}{l}\text { Pelecypods too distorted to iden- } \\
\text { tify }\end{array}$ & 22,31 & $\mathrm{Dmh}$ \\
\hline Pentamerella sp & & Dmh \\
\hline Petrocrania sp_- & 22 & $\mathrm{Dmh}$ \\
\hline Phacops rana & $22,32,34,5$ & Dmh, Dtr \\
\hline Phaethonides gemmaer & $27-\cdots-$ & Dmh \\
\hline Platyceras $\mathrm{sp}_{-} \ldots$ & 28,51 & $\mathrm{Dmh}$ \\
\hline Plethomytilus oviform & $27-=$ & Dmh \\
\hline Pleurodictyum $\mathrm{sp}_{-}$ & 32,51 & Dmh \\
\hline Productella $\mathrm{sp}_{-}$ & 25,26 & Dtr \\
\hline $\begin{array}{l}\text { Protoleptostrophia per } \\
\text { Pseudaviculopecten } \mathrm{sp}\end{array}$ & $\begin{array}{l}22,27,51,90 \\
27\end{array}$ & $\begin{array}{l}\mathrm{Dmh} \\
\mathrm{Dmh}\end{array}$ \\
\hline $\begin{array}{l}\text { Pseudaviculopecten } \mathrm{sp} \\
\text { Rhipidomella } \mathrm{sp} .+-\end{array}$ & $32 \ldots \ldots$ & $\mathrm{Dmh}$ \\
\hline cyclas......... & 22,51 & Dmh \\
\hline Schizodus sp. & 31 & Dmh \\
\hline Schuchertella $\mathrm{sp}$ & 27,51 & $\overline{D m h}$ \\
\hline Sphenomya cuneata. & $26 \mathrm{~A}$ & Dmh \\
\hline Spinatrypa spinosa.- & $22,23,27,32,44,75,90$ & $\mathrm{Dmh}$ \\
\hline Spinocyrtia? sp_- & 47 & Dmh \\
\hline Spiriferoids sp & $23,26,76$ & Dmh, Dtr \\
\hline Spirifer sculptilis... & $51 \ldots \ldots$ & Dmh \\
\hline tullius. & 51. & Dmh \\
\hline Spyroceras crotalum & & Dmh \\
\hline Stropheodonata $\mathrm{sp}$ & 27 & Dmh \\
\hline concava $=$ Megastro & & Dmh \\
\hline Sulcoretepora incissurata & $27,51 \ldots$ & Dmh \\
\hline Syringopora sp..... & $35-51-55$ & Dmh \\
\hline Taeniopora exigua - & $34,51,75$ & Dmh, Dtr \\
\hline Tellinopsis subemarg & 73 & Dcb \\
\hline
\end{tabular}


TABLE 8.-Devonian marine fossils from the northern part of the Lehighton, Pa., quadrangle and some adjoining areas and localities in which they occur-Continued

Rock unit: Dmb Marcellus and Hamilton formations, undivided;

Dtr Trimmers Rock sandstone of Susquehanna group;

Dcb Beaverdam Run member of Catskill formation of Susquehanna group.

\begin{tabular}{|c|c|c|}
\hline Name & Locality (No. on pl. 1) & Rock unit \\
\hline $\begin{array}{l}\text { Tentaculites sp } \\
\text { Tropidoleptus carinatus } \\
\text { Tylothyris? sp } \\
\text { Vertumnia undosus }\end{array}$ & $\begin{array}{l}23,24,26 \ldots- \\
32,51, \ldots \\
51,1, \ldots\end{array}$ & $\begin{array}{l}\text { Dmh, Dtr } \\
\text { Dmh } \\
\text { Dmh } \\
\text { Dmh }\end{array}$ \\
\hline
\end{tabular}

HK6-22 Quarry in north Weissport-Long Run area

HK6-23 5,000 ft west of Forest Inn and $500 \mathrm{ft} \mathrm{south}$ of road junction $602 \mathrm{ft}$.

HK6-24 $1,000 \mathrm{ft}$ south of HK6-23.

HK6-25 $300 \mathrm{ft}$ south of Route 209 at west end of Kresgeville.

HK6-26 $5,000 \mathrm{ft}$ northeast of Forest Inn and 1,400 ft west of road junction $966 \mathrm{ft}$.

HK6-26A 750 ft west of $\mathrm{HK} 6-26$

HK 6-27 $3,300 \mathrm{ft}$ northeast of mouth of Sawmill Run, 1,000 ft northeast of road junction $506 \mathrm{ft}$ and $100 \mathrm{ft}$ north of highway.

HK $6-28 \quad 4,000 \mathrm{ft}$ north of HK $6-27$.

HK6-29 Quarry about 1,500 ft east of station 395 on Turnpike and $250 \mathrm{ft}$ north of road junction $779 \mathrm{ft}$.

HK6-30 Road junction 1,250 ft south of Upper Pine Run School.

HK6-31 Road cut 2,500 ft north-northwest of Trauchsville BM $947 \mathrm{ft}$.

HK6-32 2,000 ft east-northeast of Kibler School and $75 \mathrm{ft}$ north of highway.

HK6-33 On Wild Creek below lower reservoir and $250 \mathrm{ft}$ south of highway.

HK6-34 Along gravel road opposite farm house $4,570 \mathrm{ft} \mathrm{north}$ of Kresgeville.

HK6-35 East side of paved road, north of bridge across Little Creek about 3,000 ft northnorthwest of junction of Dottersville road with U.S. Route 209 in Kresgeville.

HK6-36 East side of Dottersville-Kresgeville road about $5,700 \mathrm{ft}$ north-northwest of Kresgeville and about 2,900 ft north-northwest of highway bridge over Little Creek.
HK6-38 On secondary road 7,600 ft west-northwest of Kresgeville and 4,750 $\mathrm{ft}$ east-southeast of road junction $1,050 \mathrm{ft}$.

HK6-44 On east side of Bauer Creek about $2,000 \mathrm{ft}$ north of bighway and south of secondary road be tween junctions $1,069 \mathrm{ft}$ and $834 \mathrm{ft}$.

HK6-46 East end of dam (lower) Wild Creek Reservoir.

HK6 47 Quarry at north edge of Lehighton.

HK6-51 West bank of Pine Run 1,200 ft soutbwest of Lower Pine Run School.

HK6-71 Float in field on top of hill 1,000 ft northnorthwest of road junction $955 \mathrm{ft}, 4,000 \mathrm{ft}$ east of Trauchsville.

HK6-73 Float in field 1,600 ft east-northeast of point on highway 10,700 ft north of Kresgeville.

HK6-75 $200 \mathrm{ft}$ west of Bauer Creek on south side of Harrity-Kibler School highway.

HK6-76 On east bank of Bauer Creek 3,500 ft north of Kibler School-Kresgeville highway.

HK6-77 1,100 ft north-northwest of road junction $834 \mathrm{ft}$ of Kibler School-Kresgeville highway.

HK6-90 About 900 it west of Pine Run along Big Creek-Lovett School Road.

HK6-91 Near Walcksville at highway location $396+20$ on northeast extension of Pennsylvania Turnpike.

HK6-92 Near Walcksville at highway location $396+66$ on northeast extension of Pennsylvania Turnpike.

Subdivision of the Marcellus and Hamilton formations and the Trimmers Rock sandstone on the basis of faunal differences may be possible but would involve a regional study and was not attempted as part of this project.

A slightly curved fossil spine or bone about 5 inches long, which tapers from about $3 / 4$ to $1 / 2$ inch wide, was found by F. A. Fitch $3 \mathrm{~d}$ in gray sandstone of the Cherry Ridge member of the Catskill formation on the north side of the Penn Haven Junction uranium occurrences east of the Lehigh River. The fossil was identified by Dr. D. H. Dunkle, of the U.S. National Museum (oral communication, 1957), as a fish or shark spine, probably from a fresh-water creature that from the nature of the cell structure may represent Acanthodii gyrocanthus. X-ray spectrometer analysis of the white fossil material 
shows that francolite, a form of carbonate apatite, and quartz are the major constituents.

\section{WATER RESOURCES}

Water is the most important commodity that is utilized from the project area. The water supply for the city of Bethlehem, Pa., and for the Bethlehem Steel Co. is impounded in a reservoir on Wild Creek behind a dam in the gap in Indian Hills, west of Kibler School. Another reservoir is being built upstream on Wild Creek at the foot of Call Mountain to supplement the storage facilities. The annual consumption of water by the city of Bethlehem and by the Bethlehem Steel Co., as reported in the fifth annual message of Mayor E. E. Schaffer to the members of the council and citizens of Bethlehem, Pa., January 1955, was $3,584,169$ gallons and 2,377,941,000 gallons respectively.

The water supplies of the local communities are also obtained locally, mostly from wells. These have been described by Lohman (1937).

\section{MINERAL RESOURCES}

\section{STONE AND SLATE}

Flagstone for paving and sandstone and conglomerate have been quarried locally for use in construction work on retaining walls, bridge abutments, and the old canal along the Lehigh River. No rock was being quarried commercially in the project area in the period between 1953 and 1958, but rock excavated locally along the right-of-way of the northeastern extension of the Pennsylvania Turnpike was used for fill in nearby places along the turnpike.

Small amounts of slate were quarried locally in the southern part of the project area but were apparently not of commercial significance. The quarries are relatively small and some may have been little more than test pits.

\section{COAL}

Anthracite coal has been produced from strip mines that extend from the coal basin to the west into the western edge of the project area, but the production from within this area has been insignificant and there probably are no commercially important beds of unmined coal in the area.

\section{URANIUM}

Two deposits that are of potential commercial value as sources of uranium are known in the area. These are the Penn Haven Junction occurrences along the Lehigh River south of Penn Haven Junction and the Mount Pisgah occurrence, which has been prospected on the north side of the nose of Mount Pisgah along U.S. 
Route 309 near Jim Thorpe (pl. 1, $4^{\mathrm{w}}, 4^{\mathrm{E}}$, and 2). Other occurrences of uranium are along Mauch Chunk ridge southeast of Jim Thorpe and south of Butcher Hollow along the Lehigh River, about 4 miles north of $\operatorname{Jim}$ Thorpe (pl. 1, $1^{\mathrm{w}}, 1^{\mathrm{E}}, 3^{\mathrm{w}}$, and $3^{\mathbf{E}}$ ). These occurrences have been described recently by Dyson (1954), Montgomery (1954), Klemic and Baker (1954), McCauley (1957), and Klemic (1962). A general description of each of the uranium occurrences is given here, along with additional information that has become available for publication since the writing of the reports listed above.

\section{PENN HAVEN JUNCTION OCCURRENCES}

The Penn Haven Junction uranium occurrences are exposed on the east and west sides of the gorge of the Lehigh River about 2,000 feet south of Penn Haven Junction (pl. $1,4^{\mathrm{W}}$, and $4^{\mathrm{E}}$ ). The deposit is in a small anticlinal structure on the north limb of the Broad Mountain anticline. A map of the uranium occurrences is shown on plate 2 , with cross sections that show the distribution of radioactive rock and of fractures and bedding planes in the rock.

Uranium occurs in gray low-rank graywacke sandstone in the Cherry Ridge redbed member of the Catskill formation of Late Devonian age. The rock is tough fine- to coarse-grained sandstone with a micaceous and chloritic matrix. It has low porosity and apparently has low permeability.

The uranium occurs in zones that parallel bedding in general but also cross the bedding. Uranium also occurs in concentric zones on curved or ellipsoidal structures that are similar to rolls in the uranium deposits of the Colorado Plateau. The uraniferous rock around one such roll has been cut by a major joint that is encrusted with quartz. The uraninite is stable in the ground waters that permeate the rock formation except under surface conditions. Secondary uranium minerals are not very abundant even though some of the rock is quite rich in uranium.

\section{URANIFEROUS ROCK}

Petrographic studies were made of a suite of thin sections from thin beds of rich uraniferous fine- to medium-grained sandstone from the western uranium occurrence near Penn Haven Junction (pl. $\left.1,4^{\mathrm{w}}\right)$. This rock is interlayered with coarser grained uraniferous rock and with fine- to coarse-grained rock that is similar in appearance but barren of uranium. The thin sections were cut to give complete coverage across the beds - a total thickness of about 8 inches. The upper bed is a lensing layer, possibly representing an edge of a channel a few inches deep, with some heavy mineral layering in the channel filling. The lower part is a bed about 5 inches thick, with 
a few heavy mineral layers. The sections are labeled $A$ to $G$ and I to $\mathrm{M}$, from top to bottom. A list of the sections and of the abundance of the various mineral components in each section as determined by point counts is given in table 9 .

Uranium occurs in the form of uraninite, as very fine black or dark-gray specks about 5 microns in diameter and slightly larger. The uraninite is mostly interstitial to the clastic grains as aggregates of black particles around the borders of the grains, between the grains and matrix; and it also occurs disseminated in the matrix material.

TABLE 9.-Composition of thin sections of uraniferous rock of the Catskill formation near Penn Haven Junction, Carbon County, $P a$.

[Accessory minerals: A, abundant; C, common; R, rare. Percentage estimates based on point counts by J. C. Warman]

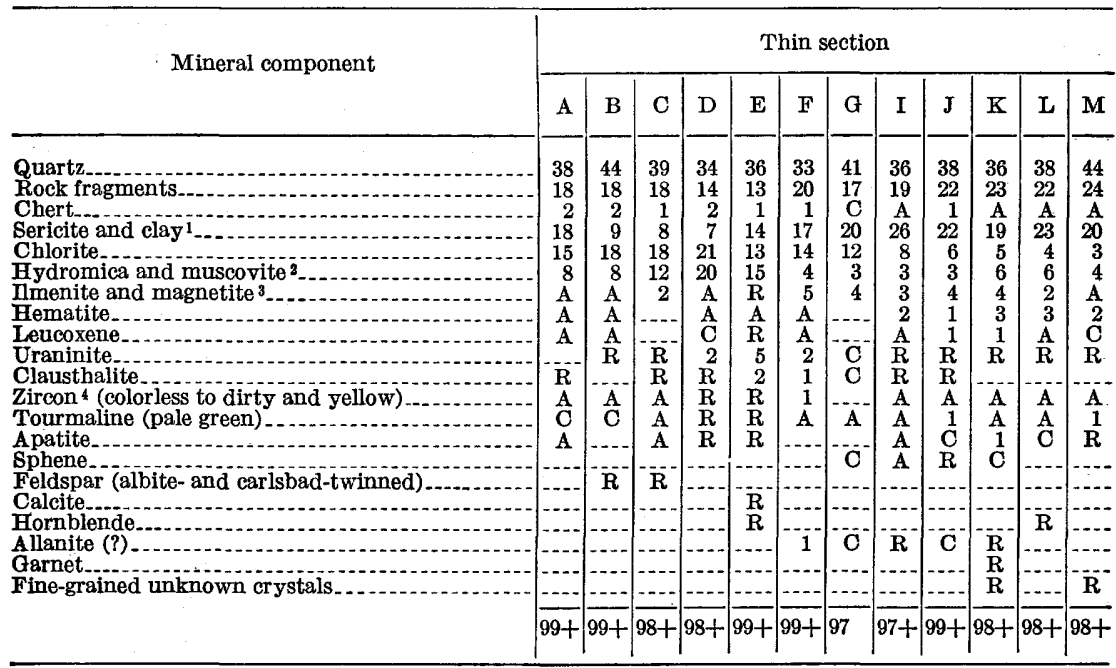

1 Clay-size micaceous matrix material.

Micaceous material larger than clay size and in oriented curved bundles.

Magnetic separation tests of samples of these rocks indicate that magnetite is relatively rare.

- Minerals of high refractive index and similar in appearance to subhedral fragments of zircon were counted as zircon. Some of the rounded grains may be monazite.

Small cracks alined parallel to bedding occur in zones in the clastic granular minerals but are not recognizable in the matrix minerals. The small cracks in the clastic grains do not contain uraninite, and autoradiographs of thin sections show that the cracks are not radioactive and therefore do not contain secondary uranium minerals. Larger chlorite-filled cracks do contain secondary uranium minerals in some sections of the rock.

The uraninite is most abundant in parts of the rock that contain heavy-mineral layers. Tiny particles of uraninite located by autoradiographs of thin sections are clustered around the clastic grains of the heavy minerals and disseminated in the rock. Thin layers rich in ilmenite, magnetite, leucoxene, and pyrite and other layers rich in 
zircon and partly decomposed allanite (?) are paralleled by and included in layers and zones rich in uraninite, but all of these minerals also occur in a more disseminated manner in the rock.

Kasolite $\left[\mathrm{Pb}\left(\mathrm{UO}_{2}\right) \mathrm{SiO}_{4} \cdot \mathrm{H}_{2} \mathrm{O}\right]$ and uranophane $\left[\mathrm{Ca}\left(\mathrm{UO}_{2}\right)_{2} \mathrm{Si}_{2} \mathrm{O}_{7} \cdot 6 \mathrm{H}_{2} \mathrm{O}\right]$ are two of the secondary minerals found at the Penn Haven Junction occurrence. Others that may be present have not been identified. Fluorescent secondary uranium minerals are rare or absent.

Clausthalite (PbSe) occurs in fine irregular particles and is distributed in a manner similar to uraninite. The clausthalite, however, is coarse enough to be detected by its metallic glint on freshly broken surfaces. The greatest concentration of clausthalite appears to be in the most uraniferous parts of the deposit. Thin bands rich in uraninite and others rich in clausthalite occur within a fraction of an inch of each other in thin sections of this rock. Both minerals are also disseminated in the rock. In some samples clausthalite is more abundant than uraninite, but in most of the rock uraninite is more abundant. Small amounts of pyrite are associated with the clausthalite as inclusions and as separate grains, and from the shapes and relations of these minerals, it is likely that they crystallized in their present position in the rock, for they have angular extensions that fill the available spaces in the matrix. Some of the red earthy material that has been called hematite in the uraniferous rock may be a selenium bloom from weathered clausthalite.

Spectrographic analyses and preliminary petrographic descriptions of uraniferous rock from the Catskill formation in the project area have been published in a previous report (Klemic and Baker, 1954). The clausthalite was originally thought to be galena, but no galena has been identified in X-ray spectrometer analyses of the heavy mineral separates in which clausthalite has been identified (Robert Coleman, written communication, 1956).

Samples of the uraniferous rock assay as much as 0.56 percent uranium, and some samples contain as much as 0.066 percent selenium, which would be about 0.24 percent clausthalite.

Feldspar is not abundant in the rock. Sericite and chlorite are the major matrix minerals. Some muscovite is present and small amounts of calcite cement the rock.

\section{DISTRIBUTION AND EXTENT}

The distribution of the radioactive rock is shown in plate 2 . The radioactivity of the rock and the position of various features of the deposit were measured carefully. The outlines of the radioactive zones as shown do not coincide exactly with the outlines of the zones of uraniferous rock but extend beyond the uraniferous rock a little because of diffusion of the radioactivity away from its source. 
Uraniferous rock occurs over widths of 300 feet in cross sections of the small fold on both sides of the Lehigh River. The sections are about 400 feet apart. The well-developed roll structure exposed in the northern part of the section ( $\mathrm{pl} .2$ ) on the west side of the river is unique, but the long zone that parallels bedding and turns up across the bedding has a counterpart on the east side of the river in about the same position on the fold. This may have been part of a continuous mineralized zone. If such a zone, about 400 feet long, existed before the river cut through the deposit, the deposit may extend for a considerable distance in from the outcrop on both sides of the river, for there is only a little difference in the dimensions of the strongly radioactive zone that curves upward across the bedding in both sections. The part of the zone that parallels bedding is larger and more strongly radioactive on the west side than on the east.

A rather striking feature of the distribution of the radioactive rock on the east side of the river (pl. 2) is that it follows up the dip of the bedding, then drops about 16 feet and again curves upward to follow the bedding. This pattern of distribution has the appearance of the outline of the bases of a series of channels, but features of the rock such as pebbly zones or other layered zones continue along the bed across the radioactive zones. Except for the two small and weakly radioactive zones about 15 feet higher stratigraphically, it appears that there was a level in the fold as it is now situated above which the uranium was not deposited, or above which uranium has been removed in some manner. The continuity of the zones of radioactivity that turn downward are due in part to the deposition of secondary uranium minerals on the surface, but some of the zones contain only small amounts of secondary minerals and the strong radioactivity is probably due to interstitial uranium in the rock. A feature such as an interface between ground waters of slightly different composition, or water-oil, or oil-gas, or water-gas surfaces may have permitted deposition of uranium below but not above the contact. This does not explain the small zones above the main zone.

A few other features of the outcrops on both sides of the river are worthy of comment. Secondary uranium minerals are not abundant in the deposit but are more abundant on the outcrop east of the river than on the west. The eastern outcrop is along a few parallel major joints that trend about $\mathrm{N} .30^{\circ} \mathrm{W}$. and dip about $71^{\circ} \mathrm{SW}$. These form smooth cliff faces 30 or more feet high in massive sandstone beds, and they continue much higher. The smooth joints are spaced about 2 to 6 feet from each other. Much of the outcrop on the east side of the river appears to be naturally exposed and the rock is weathered on the surface. On the west side of the river, however, most of the face of uraniferous rock has been exposed in a cut made to widen the area 
for another set of railroad tracks. Although the rock at the face of the cut may have been within 10 or 20 feet of the surface before the cut was made, it is relatively unweathered, and uraninite occurs near the surface. Only small amounts of secondary minerals occur in the rock and these are near bedding-plane or fracture surfaces. The rock therefore must be relatively impermeable.

Before the river cut through it, the deposit was below the water table in the valley. The surface above which little uranium is present at outcrop may represent a long-lasting water level that existed prior to the downcutting of the river valley by the postglacial runoff waters. Uranium above this old valley water table may have been oxidized and leached away. Secondary minerals may thus be relatively scarce because uranium was carried elsewhere rather than being deposited on the surfaces or in the interstices of rocks in which it was oxidized.

The zones of uraniferous rock near Penn Haven Junction and on Mauch Chunk Ridge occur in the Cherry Ridge redbed member of the Catskill formation. The deposit near Penn Haven Junction is a few hundred feet closer stratigraphically to the base of the Pocono than the uraniferous rock is on Mauch Chunk Ridge, and unless the upper beds of the Cherry Ridge member thin to the north of Jim Thorpe, the uranium at Penn Haven Junction occurs higher in the Cherry Ridge member in that area than it does at Mauch Chunk Ridge-an assumption that appears reasonable to the authors.

The Penn Haven Junction uranium occurrence has not been prospected by test mining or by extensive drilling. A few shallow holes drilled by Eastern Uranium, Inc., along the cliff on the west side of the river cut radioactive rock in beds that are known to contain uranium at outcrop, but no deep drilling has been done at the deposit, and its potentialities have not been measured. The width of the outcrop of the zone of uraniferous rock, the pattern of distribution of uranium, and the position of the deposit on a minor structural feature, are very similar in two places a few hundred feet apart. Because of these features and because the minor fold may extend for a few miles in the favorable strata of the Catskill formation in the Broad Mountain anticline, the authors believe that conditions are favorable for the existence of a large uranium deposit at the Penn Haven Junction locality.

The potential economic value of this deposit depends upon many factors. Aside from factors related to price and marketing of the ores, there are problems of sampling the deposit, and others of mining rights. The part of the deposit east of the Lehigh River is on State game lands on which mining is not permitted. The outcrop of the western part of the deposit is along the right-of-way of the Lehigh Valley Railroad, but the area to the west of the railroad is privately 
owned. Access to the deposit would appear to be most practical from the railroad right-of-way, because the hillside to the west slopes at about $40^{\circ}$ and the relatively level mountain top is several hundred feet higher above sea level than the outcropping zone of radioactive rock at track level.

\section{BUTCHER HOLLOW OCCURRENCE}

South of Butcher Hollow, about 4 miles north of Jim Thorpe, uraniferous rock has been found on both sides of the Lehigh River (pl. $1,3^{\mathrm{W}}, 3^{\mathrm{E}}$ ). Talus conceals most of the bedrock on the east side. The outcrop on the west side is along the right-of-way of the Lehigh Valley Railroad; the adjoining area to the west and the land on the east side of the river are on State game lands.

The Butcher Hollow occurrence is exposed in a small anticlinal fold similar to that at the Penn Haven Junction occurrence (Klemic and Baker, 1954). The uranium is in gray sandstone and siltstone of the Cherry Ridge member of the Catskill formation, in approximately the same stratigraphic position as the Penn Haven Junction occurrence. At the Butcher Hollow occurrence, there is more siltstone and micaceous sandstone in the minor anticline and the uraniferous rock is more weathered. Secondary uranium minerals are not abundant. A sketch showing the distribution of radioactive rock and the fracture systems along the outcrop on the west side of the river is shown on plate 2 .

No new sampling was done at this occurrence, but the results of spectrographic analysis made of a sample during an earlier study are given in table 10. For additional results of spectrographic analyses, the reader is referred to reports by Klemic and Baker (1954) and Klemic (1962).

A sample of rock known to contain 0.055 percent uranium was found to contain 0.022 percent selenium. The selenium may be in the form of clausthalite, but the sample was not examined specifically for clausthalite.

The Butcher Hollow uranium occurrence does not contain large strongly radioactive zones at outcrop. This may be due to the fact that the rock is weathered and the uranium has been leached away. The distribution of radioactive rock around a barren zone as shown on plate 2 gives a false appearance of a roll structure. The rock along bedding-plane fractures and irregular smaller fractures contains secondary uranium minerals, but the less fractured part of the rock is barren. The most strongly radioactive rock found at this outcrop is a porous and punky light-brownish-gray lens a few inches thick and about 6 inches long, with disseminated secondary minerals. The distribution of radioactivity in the outcrop suggests that much of the 
radioactivity is caused by secondary uranium minerals that have formed along fractures. No samples of unweathered uraniferous rock have been obtained from this occurrence, but both uraninite and clausthalite may well be found in unweathered rock deeper in the hillside.

\section{MAUCH CHUNK RIDGE OCCURRENCE}

The uranium occurrence on Mauch Chunk Ridge, about 0.4 mile south of the courthouse in Jim Thorpe, is exposed along the south side of U.S. Route 309 and extends spottily for about three-quarters of a mile along strike to the east side of the railroad bridge that crosses the Lehigh River about a mile east of Jim Thorpe (pl. 1, $1^{\mathrm{w}}, 1^{\mathrm{E}}$ ). The occurrence is along the right-of-way of the Central Railroad of New Jersey and on privately owned property. It has been described by Dyson (1954), Montgomery (1954), Klemic and Baker (1954), and Klemic (1962).

The uranium on Mauch Chunk Ridge is in steeply dipping gray sandstone in the lower part of the Cherry Ridge member of the Catskill formation, about 900 feet below the base of the Pocono formation on the south limb of the Mount Pisgah-Call Mountain syncline. Uranium occurs in a few beds, but 2 beds about 25 feet apart stratigraphically are the most strongly radioactive. Where the rock is radioactive, the upper bed is 4 to 8 feet thick and the lower bed is about 4 to 6 feet thick.

The rock is a low-rank graywacke sandstone with micaceous surfaces. Uranium occurs in tiny dark specks a few microns in diameter disseminated in the rock. Small amounts of autunite, torbernite, and uranophane have been found in these rocks, and Montgomery (1954, p. 107) reported meta-autunite, possibly metauranocircite, and metatorbernite. Small amounts of malachite staining were noted in the radioactive rock on the east side of the Lehigh River.

The uraniferous rock on Mauch Chunk Ridge was sampled by test drilling by the Lehigh Coal and Navigation Co. in 1954, but no development work was done afterwards. The part of this occurrence east of the Lehigh River was prospected by Mr. Raymond Zimmerman of Weissport, $\mathrm{Pa}$.

Samples of rock that contain as much as 0.13 percent uranium have been obtained from this occurrence, but most of the rock sampled contains less uranium.

\section{MOUNT PISGAH OCCURRENCE}

This uranium occurrence is on the north side of the nose of Mount Pisgah, near Jim Thorpe, on property owned by the Lehigh Coal and Navigation Co. Uraniferous rock in the basal conglomeratic bed of the Mauch Chunk-Pottsville transition zone crops out from the

$675114-63-7$ 
trough of the syncline westward for a distance of about 2,000 feet. The most strongly radioactive rock is exposed near road level in cliffs along the south side of U.S. Route 309 (pl. 1, No. 2).

The reader is referred to reports by Wherry (1915), Dyson (1954), and Montgomery (1954) for their descriptions and impressions of this deposit. The reports by Dyson and Montgomery contain some information from core drilling and test mining by the Lehigh Coal and Navigation Co. in 1953.

The uranium-bearing conglomeratic bed strikes about N. $82^{\circ} \mathrm{E}$. and dips $20^{\circ}$ to $40^{\circ} \mathrm{SE}$. Uranium in an unidentified black form and in brightly colored secondary minerals occurs in two zones about 10 feet apart stratigraphically, but the distance between these zones is variable. Most of the test mining and sampling was from the lower zone, which is the thicker one in the outcrop along the highway. The rock contains channels, crossbedded zones, and lenses of conglomerate and sandstone of varying thickness. Bedding-plane surfaces and partings in some places are oriented with respect to these minor features, and on a small scale they vary noticeably from the main trend of the formation. The general distribution of uranium along the line of outcrop is parallel to the bedding.

The fossil logs or plant stems that are oriented southwestward and the southwestward elongation of some zones of uraniferous rock suggest that there may be a zone of southwesterly trending channels in the rock. The length of the uraniferous zone along strike suggests a westerly or southwesterly elongation of the deposit; however, its extension downdip is not known, and it may be a blanket-type deposit.

The occurrence of uranium-rich zones in rolls and around curved ovoid bodies of barren rock was noted during the test-mining operations. In one place, in gray sandstone, a layer of sandstone rich in the black uranium mineral curved over the top and around one end of an ovoid mass of barren sandstone, and the uraniferous zone ended abruptly beneath the roll, although the concentric rock layer continued under the roll with no change in the appearance of the rock.

The unidentified uranium mineral, in the form of black particles a few microns in diameter, occurs interstitially in graywacke sandstone and conglomerate with a sericitic and chloritic matrix and abundant calcite cement. Descriptions of these rocks are given on pages 48-51. Some uranium is in sericitic and chloritic shale. Uranium is generally most abundant in rocks with a dark matrix, but some of the dark rock is barren of uranium.

As in the uraninite-bearing rock at the Penn Haven Junction occurrence, thin black layers of rock are very rich in uranium and lesser amouts of uranium are disseminated above and below the rich layers. These layers parallel the bedding for distances of a few feet; they 
may extend farther, but their limits were not determined during the test mining. Some of the thin black layers may contain a few percent of uranium. One specimen with black material assayed 1.8 percent uranium and 0.04 percent selenium. No clausthalite has been found by the authors in the Mount Pisgah uranium deposit.

The uraniferous rock is fractured irregularly and some of the fractures are sealed by quartz and calcite. Thin zones of clastic grains that are crossed by parallel cracks have been observed in thin section. Unidentified black material is found in narrow fractures in pebbles, but much of this material is not radioactive. Some of it may be radioactive owing to secondary uranium minerals or to radon and its daughter products. Narrow fractures sealed by quartz and calcite cross uraniferous zones in the rock and appear to be younger than the black uranium mineral.

Brightly colored secondary uranium minerals that have been identified in the Mount Pisgah deposit include carnotite, tyuyamunite, liebigite, uranophane, and betauranophane. The uranium carbonate, andersonite, and the carbonate-sulfate, schroeckingerite, have also been reported (Montgomery, 1954, p. 106-107). Carnotite and tyuyamunite indicate the presence of vanadium, which also occurs in an unidentified black or gray form in the uraniferous rock.

The secondary minerals are in weathered zones and on fracture surfaces of the rock. Black "ore" is more abundant than rock rich in secondary uranium minerals. Most of the rock is well cemented and relatively impermeable, but a few weathered porous lenses rich in secondary uranium minerals were exposed in mining. The secondary minerals in these lenses may have resulted from oxidation of primary uranium minerals in the same rock. The lenses were near the surface, and ground water moving from open fractures or bedding-plane partings could have caused the oxidation, if the rock in the lenses were poorly cemented and more permeable than the adjoining rock. Secondary uranium minerals also occur on fracture surfaces and in partings of rock that is otherwise barren of uranium.

\section{SPECTROGRAPHIC ANALYSES}

The results of spectrographic analyses of samples of uraniferous sandstone from each of the various uranium occurrences in the project area are listed in table 10 for comparison. Others are included in another report (Klemic, 1962).

\section{ORIGIN}

The origin of the uranium occurrences in the project area has been discussed by various writers. Wherry $(1915$, p. 147-151) considered the deposit on Mount Pisgah to be a placer-type deposit. Montgomery (1954, p. 108-110) stated that the uranium may have been brought 
TABLE 10.-Results of spectrographic and chemical analyses of uraniferous rock from uranium occurrences in Carbon County, $P a$.

[Spectrographic analyses, analysts: K. E. Valentine, Charles Annell, K. V. Hazell, H. W. Worthing. Chemical analyses, analysts: E. Campbell, J. Budinsky, R. Moore]

\begin{tabular}{|c|c|c|c|c|}
\hline \multirow[b]{3}{*}{$\begin{array}{l}\text { Sample... } \\
\text { Lab. no.. }\end{array}$} & \multicolumn{4}{|c|}{ Uranium occurrences } \\
\hline & $\begin{array}{l}\text { Mauch Chunk } \\
\text { Ridge }\end{array}$ & Butcher Hollow & $\begin{array}{l}\text { Penn Haven } \\
\text { Junction }\end{array}$ & Mount Pisgah \\
\hline & $\begin{array}{l}\text { HK3-37 } \\
115028\end{array}$ & $\underset{115034}{\mathrm{HK} 3-43}$ & $\begin{array}{l}\text { HK3-50 } \\
115037\end{array}$ & $\underset{150414}{\text { MC-PVS }}$ \\
\hline $\begin{array}{r}\text { Percent } \\
\mathrm{x} 0 \ldots . .1\end{array}$ & $\mathrm{Si}$ & Si_... & Si_...... & \\
\hline x..... & $\begin{array}{l}\text { Al_........ } \\
\text { Fe....... }\end{array}$ & Al $\mathrm{Fe} . . . . . . . . .$. & $\mathrm{Al} \ldots$ & $\begin{array}{l}\text { Al, Fe. } \\
\text { U,'Ca. } \\
\text { V', P. }\end{array}$ \\
\hline x...... & $\begin{array}{l}\mathrm{K}, \mathrm{Mg} \\
\mathrm{Ca}, \mathrm{Ti}\end{array}$ & $\begin{array}{l}\mathrm{Mg}, \mathrm{Ca} \\
\mathrm{U}, \mathrm{Ti} .\end{array}$ & $\begin{array}{l}\mathrm{Mg}, \mathrm{Ca} \\
\mathrm{Ti}, \mathrm{Pb}_{2} \\
\mathrm{U}\end{array}$ & $\begin{array}{l}\text { Mn, Ba. } \\
\text { Na, Mg. } \\
\text { As, Ti. }\end{array}$ \\
\hline $.0 x \ldots$ & 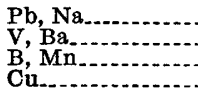 & $\begin{array}{l}\mathrm{Pb}, \mathrm{Mn} \\
\mathrm{Ba}, \mathrm{Na} \\
\mathrm{B}, \mathrm{V}\end{array}$ & $\begin{array}{l}\mathrm{Ba}, \mathrm{Mn} \\
\mathrm{V}, \mathrm{Na} \\
\mathrm{B}, \mathrm{Co}\end{array}$ & $\begin{array}{l}\text { Pb, B. } \\
\text { Li. }\end{array}$ \\
\hline $.00 x$ & $\begin{array}{l}\text { Ni, Cr. } \\
\text { Sr, Ga } \\
\text { Y, Zr... }\end{array}$ & $\begin{array}{l}\text { Co, } \mathrm{Cu} \\
\text { Ni, Cr... } \\
\text { Y, } \\
\text { Ga }\end{array}$ & $\begin{array}{l}\mathrm{Zr}, \mathrm{N1} \\
\mathrm{Cu}, \mathrm{Y} \\
\mathrm{Cr}, \mathrm{Gr} \\
\mathrm{Sr}\end{array}$ & \\
\hline $.000 x$ & $\mathrm{Be}, \mathrm{Yb}_{\ldots}$ & Yb & Yb........ & \\
\hline $\begin{array}{l}\text { Percentage uranium.-- } \\
\text { Percentage selenium.- }\end{array}$ & $\begin{array}{l}0.13 \\
0.038\end{array}$ & 0.22 & $\begin{array}{l}0.30 \\
0.066\end{array}$ & $\begin{array}{l}1.8 \\
0.040\end{array}$ \\
\hline
\end{tabular}

in by hydrothermal solutions or may have been extracted and concentrated from detrital minerals by hydrothermal solutions. Dyson (1954, p. 128-134) discussed the various factors that must be considered in trying to account for the origin of the deposits. The stratigraphic relations of uranium occurrences in sedimentary rocks in Pennsylvania were described by the senior author (Klemic, 1962).

The uranium occurrences in the project area are believed by the senior author to have formed by epigenetic concentration of uranium that may have been deposited syngenetically in the host formations. These conclusions are based on the following factors:

1. The ultimate source of the uranium is unknown; however, the uranium occurs in sedimentary rocks, and it is possible that it was precipitated chemically from the waters in which the sediments were deposited.

2. Uranium occurs in about the same stratigraphic horizons in widely separated localities in Pennsylvania and in southeastern New York. This suggests syngenetic deposition.

3. The distribution of radioactive rock in the Penn Haven Junction uranium occurrence, as shown on plate 2, suggests partial structural control of the deposition of uranium. It occurs in and 
around features of the rock that are believed to be of post sedimentary origin, such as the ellipsoidal structures and the minor anticlinal fold. If the uraniferous rock once extended from one side of the river to the other, as the authors believe, then stratigraphic control was also pronounced, for the uraniferous zone maintains its stratigraphic position along the strike of the small anticline. Uraniferous rock also occurs around ellipsoidal structures in the Mount Pisgah deposit, and uraniferous zones cross the bedding and vary abruptly in uranium content with no apparent relation to other features of the rocks.

4. The uraninite occurs in tiny particles around clastic grains and in the matrix of the rock in a manner that suggests that it was precipitated from solution.

5. The clausthalite in the uraniferous rock at the Penn Haven Junction occurrence has a distribution quite similar to that of uraninite. The clausthalite particles have shapes that indicate epigenetic origin.

The final deposition of uraninite in these rocks probably occurred in Pennsylvanian time or later, but prior to the development of the major sets of northwestward-trending joints, some of which cut uraniferous rock around roll structures.

Hydrothermal solutions or ground waters below the zone of oxidation may have moved and concentrated the uranium, but no positive evidence for hydrothermal solutions from a magmatic source has been recognized. Although subsidence of the area during sedimentation is likely to have been slow enough to permit the maintenance of a relatively normal temperature gradient, there may have been significant changes in the temperature of the rocks and their enclosed waters. The structural deformation that occurred in this area at the close of Paleozoic time probably altered the movement of subsurface waters. During folding and metamorphism, waters in the interstices of deeply buried and downfolded reservoir rocks may have become heated. If such waters were released by faulting and fracturing or by dissolving of cementing materials in the rock, they might move upward and permeate overlying rocks. During the course of the movement, hydrothermal redistribution and concentration of uranium in permeable beds that contained syngenetic uranium might readily occur.

The above interpretation of the origin of the deposits is in general agreement with that of Montgomery but is more restrictive in that the source of the uranium is considered to have been the sediments that make up the rock. The crystalline rocks of areas to the east are considered a possible source of some of the uranium that was deposited with the sediments. Thorium is relatively abundant with respect to uranium in radioactive minerals in the crystalline rocks, and uranium 
deposits that were placer or detrital concentrations of these minerals would contain noticeable amounts of thorium. Uranium deposits formed by epigenetic concentration of uranium that was previously deposited as a syngenetic precipitate in the sediments would, however, probably be relatively low in thorium, as these deposits are.

\section{GEOCHRONOLOGY}

Age studies of samples of uranium and lead in sandstone from the Penn Haven Junction and Mount Pisgah uranium occurrences were made by L. R. Stieff and T. W. Stern using lead and uranium isotope ratios.

Corrections were made for original common lead using $\mathrm{Pb}^{208}$ as an index. Samples were corrected using lead isotope ratios in galena from Pennsylvanian rock a few miles west of the mapped area (sample HK8-1, lab. No. GS/584/57) and separates of clausthalite from uraninite-rich rock from the Penn Haven Junction uranium occurrence (pl. 1, 4 ${ }^{\mathrm{w}}$, sample HK6-SE2, lab. No. GS/512/56). The uraniferous sandstone at the Penn Haven Junction uranium occurrence contains an excess of lead due to the presence of clausthalite, which is difficult to separate. This requires a large correction for lead in the samples, and the corresponding possibility of large errors.

Calculated trial ages in millions of years

\begin{tabular}{|c|c|c|c|c|c|}
\hline $\begin{array}{c}\text { Sample } \\
\text { No. }\end{array}$ & Lab. No. & Locality & $\mathrm{Pb}^{206 / \mathrm{U}^{238}}$ & $\mathrm{~Pb}^{207} / \mathrm{U}^{235}$ & $\mathrm{~Pb}^{207} / \mathrm{Pb}^{200}$ \\
\hline MCPV-8 & GS/346/54 & $\begin{array}{l}\text { Mount Pisgah, Carbon County, Pa. } \\
\text { Mauch Chunk-Pottsville transition } \\
\text { zone. }\end{array}$ & 314 & 325 & 413 \\
\hline HK6-PV & $\begin{array}{l}\mathrm{GS} / 538 / 56 \\
\mathrm{GS} / 403 / 55\end{array}$ & Penn Haven Junction, Carbon County, & $\begin{array}{l}300 \\
220\end{array}$ & $\begin{array}{l}312 \\
245\end{array}$ & 302 \\
\hline PHJ & GS/586/56 & $\begin{array}{l}\text { Pa. Catskill formation. } \\
\text {. }\end{array}$ & 438 & 428 & 368 \\
\hline
\end{tabular}

The calculated trial age of the uraniferous material in the Mount Pisgah deposit, about 300 million years, is about 35 percent greater than the estimates of the age of Late Mississippian rocks currently used by the U.S. Geological Survey. Analyses of these discordant trial ages using graphic and algebraic methods described by L. R. Stieff and T. W. Stern (1961) yield concordant ages of 115 million years and 135 million years, respectively, for the Penn Haven Junction and Mount Pisgah deposits (Stern and others, 1960).

\section{URANIUM POTENTIAL.}

On the basis of the stratigraphic distribution of uranium in the project area, the lower part of the Cherry Ridge member of the Catskill formation and the basal beds of the Mauch Chunk-Pottsville transition zone may be considered as favorable host formations for 
uranium. The known uranium occurrences in these formations are at the best exposures of the favorable beds in the project area. Elsewhere those beds are very poorly exposed. The formations have relatively steep dips in many places so that drainage from the outcropping or near-surface parts of these beds would mix with the ground waters, and uranium that might be taken into solution from these rocks would be carried into the ground water and removed, instead of being precipitated as secondary minerals on the surface. Thus, although large areas along the zone of outcrop of the lower part of the Cherry Ridge member have been reconnoitered for uranium, no uranium occurrences other than those in well-exposed rocks along the Lehigh River have been found in the project area.

In most of the area underlain by the Cherry Ridge member, the favorable host rocks are a few hundred to a few thousand feet below the surface. Excavations that cut the favorable zone below the zone of weathering are good places to examine for uranium. Secondary uranium minerals and a black mineral that may be uraninite have been found in freshly exposed rocks of the upper part of the Catskill formation in roadcuts along the northeastern extension of the Pennsylvania Turnpike in Carbon County about 3 miles and 4 miles northwest of the place where the turnpike crosses the northern border of the Lehighton quadrangle (Klemic, 1962).

The uranium occurrence at Penn Haven Junction is one of the most favorable sites for development work for uranium in the project area. Rock more than 1 foot thick that may contain more than 0.1 percent uranium occurs on both sides of the Lehigh River, and the inferred zone of uraniferous rock can reasonably be expected to extend a few hundred feet into the hillside on either side of the river. The minor fold in which the uranium occurs is part of the Broad Mountain anticline and may extend for a considerable distance along the strike of this large fold. There may have been a concentration of uranium along the structure, as suggested by the distribution of radioactive rock at outcrop. Regardless of the origin of this deposit, uraniferous rock is at the surface along the river valley in minor anticlines. The uraniferous rock is relatively rich at the site of the Penn Haven Junction occurrence, and the adjoining parts of the bed may also be rich in uranium on the flanks of the structure if the uranium was deposited syngenetically in the formation. If, however, there has been an epigenetic concentration of uranium in a favorable structure in the uraniferous bed, the possibility that the concentration may be greater at some other place along the structure than it is at outcrop should be considered.

The potential for uranium in the Mauch Chunk-Pottsville transition zone is good, but outcrops of these rocks are limited within the 
project area and the rocks dip and plunge deeper beneath the surface to the west.

The complete results of test-mining operations at the Mount Pisgah occurrence have not been made public and no further development work has been done. The tests did reveal the presence of "black ore" in the deposit in addition to the carnotite- and tyuyamunite-bearing ore. The fact that no further development was carried on at the deposit suggests that the results were not satisfactory under existing economic conditions with respect to uranium, however, the deposit has not been completely mined out. Reconnaissance in adjoining outcrop areas of the basal conglomerate of the transition zone gave negative results, and it appears that subsurface exploration originating from or near the test mining sites is the most practical method of testing the extension of the uraniferous rock.

The authors believe that if the need for uranium becomes greater and the marketing conditions for uranium in the northeastern United States improve, the Penn Haven Junction and Mount Pisgah uranium occurrences should be prospected more thoroughly.

\section{GALENA, SPHALERITE, CHALCOPYRITE, AND PYRITE}

Minor amounts of galena, sphalerite, chalcopyrite, and pyrite occur with dolomite and quartz in small irregular cross fractures and along bedding-plane partings in sandstone of the Trimmers Rock near Walcksville (pl. 1, No. 7). This rock is exposed near highway survey point 401 in a roadcut along the northeastern extension of the Pennsylvania Turnpike. The sulfide minerals are sparse in the roadcut but were slightly more abundant in some of the rock that was excavated. Galena occurs in crystals that are as much as half an inch across. Sphalerite is less abundant than galena in the rocks that were examined; it occurs in small pale honey-colored to dark-brown subhedral crystals. Chalcopyrite occurs sparsely in small irregular flakes. Pyrite in small aggregates of tiny crystals is disseminated in the rock near the mineralized fractures.

The sequence of deposition of the minerals was as follows:

1. Quartz was deposited in the open fractures. Some of this quartz was sheared by movement of the fractured rock and euhedral quartz crystallized as overgrowths on the sheared quartz.

2. The sulfides were deposited on the quartz as open-space fillings. The lead, zinc, copper, and iron sulfides probably were deposited contemporaneously, but some galena may have continued to form after the other sulfides had been deposited. Small isolated inclusions of galena occur in clear quartz. These may have formed while the quartz was crystallizing, but most of the galena is clearly younger than the quartz. 
3. Dolomite was deposited on the quartz and sulfides. Much of the dolomite weathers to a cream or rust color, which suggests that it may contain iron as an impurity. Some of the rust stain may, however, be due to the oxidation of iron-bearing sulfides.

4. Smithsonite formed residually from oxidized sphalerite, and thin films of cerussite formed on wezthered galena. Limonite formed from weathered iron-bearing sulfides.

A semiquantitative spectrographic analysis of a sample of galena from the Walcksville locality is given in table 11. The purity of the galena suggests that it crystallized at low temperature.

The isotopic composition in atom percentage of a sample of this galena as reported by L. R. Stieff and T. W. Stern is given below:

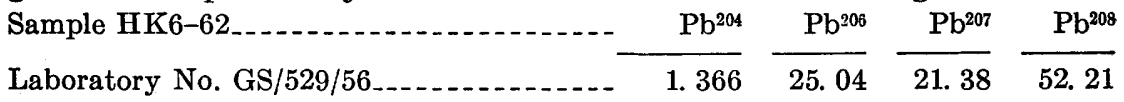

This galena is almost identical in isotopic composition with galena that occurs as fracture fillings in Pennsylvanian rocks a few miles west of the mapped area and is Pennsylvanian or post-Pennsylvanian in age. The analysts report that these galenas do not appear to be abnormally enriched in radiogenic lead, and that they compare closely in isotopic composition with samples of galena from Tertiary lead deposits in Colorado.

TABLE 11.-Semiquantitative spectrographic analysis of a sample of galena from fracture fillings in Upper Devonian rocks near Walcksville, Carbon County, Pa.

[Analysts: K. V. Hazel and H. W. Worthing]

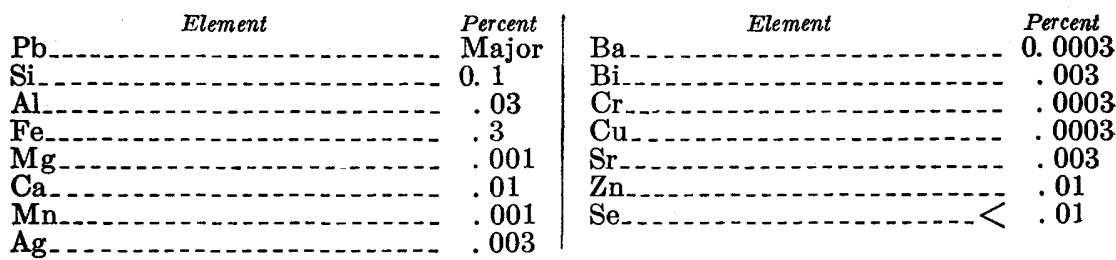

Looked for but not detected: $\mathrm{Na}, \mathrm{K}, \mathrm{Ti}, \mathrm{P}, \mathrm{As}, \mathrm{Au}, \mathrm{B}, \mathrm{Be}, \mathrm{Cd}, \mathrm{Ce}$, $\mathrm{Co}, \mathrm{Cs}, \mathrm{Dy}, \mathrm{Er}, \mathrm{Eu}, \mathrm{Ga}, \mathrm{Gd}, \mathrm{Ge}, \mathrm{Hf}, \mathrm{Hg}, \mathrm{Ho}, \mathrm{In}, \mathrm{Ir}, \mathrm{La}, \mathrm{Li}, \mathrm{Lu}$, Mo, Nb, Nd, Ni, Os, Pd, Pr, Pt, Rb, Re, Rh, Ru, Sb, Sc, Sn, Sm, Ta, Te, Tb, Th, Tm, U, V, W, Y, Yb, Zr.

\section{COPPER MINERALS}

In addition to the minor amounts of chalcopyrite in the Devonian rocks near Walcksville, trace amounts of malachite occur there and at other places shown on plate 1. Minute amounts of torbernite occur in the uraniferous rock on Mauch Chunk Ridge $\left(1^{\mathrm{w}}\right)$, and traces of malachite occur in the uraniferous rock to the northeast, at the foot of Bear Mountain $\left(1^{E}\right)$. Malachite and azurite have been noted at 
the base of the Mauch Chunk formation on the west side of the Lehigh River at Penn Haven Junction (loc. 5) and on the north side of Mud Run (loc. 6).

These minor occurrences may be indications of concealed copper sulfides in fissure fillings, or they may be traces of copper leached from unmineralized rocks or from weakly uraniferous rocks. The background radioactivity of some beds near the base of the Mauch Chunk formation on the slope north of Penn Haven Junction and on the south side of Mud Run is slightly higher than average.

\section{REFERENCES CITED}

Ashburner, C. A., 1883, The geology of the Panther Creek Basin or the eastern end of the southern field: Pennsylvania 2d Geol. Survey Rept. of Progress AA, $407 \mathrm{p}$.

1884, Sketch of the geology of Carbon County, Pennsylvania, in Mathews, Alfred, and Hungerford, A. N., History of the counties of Lehigh and Carbon in the Commonwealth of Pennsylvania: Philadelphia, Pa., p. 650-656, map.

Ashley, G. H., 1923, A geologic time scale: Eng. and Min. Jour.-Press, v. 115, no. 25 , p. 1106-1109.

- 1935, Studies in Appalachian Mountain sculpture: Geol. Soc. America Bull., v. 46 , no. 9, p. 1395-1436.

Barrell, Joseph, 1907, Origin and significance of the Mauch Chunk shale: Geol. Soc. America Bull., v. 18, p. 449-476.

1935, What is Pocono?: Am. Jour. Sci., 5th ser., v. 29, p. 133-143.

Behre, C. H., Jr., 1933, Slate in Pennsylvania: Pennsylvania Geol. Survey, 4th ser., Bull. M16, 400 p.

Cooper, G. A., and Williams, J. S., 1935, The Tully formation of New York: Geol. Soc. America Bull., v. 46, no. 5, p. 781-868.

Dyson, J. L., 1954, Relation of stratigraphy and structure to uranium occurrences near Mauch Chunk, Pennsylvania: Pennsylvania Acad. Sci. Proc., v. 28, p. 124-134.

Gault, H. R., Dalhausen, J. K., and Yeakel, Lloyd, 1957, Note on a partial section of the Pottsville-Mauch Chunk transition near Jim Thorpe, Pennsylvania: Pennsylvania Acad. Sci. Proc., v. 31, p. 114-119.

Genth, F. A., 1875, Preliminary report on the mineralogy of Pennsylvania: Pennsylvania 2d Geol. Survey Rept. B., p. 144.

Grabau, A. W., 1908, Notes on character and origin of Pottsville formation, New York: Acad. Sci. Ann., v. 18, p. 294.

Johnson, Douglas, 1931, Stream sculpture on the Atlantic slope, a study in the evolution of the Appalachian rivers: New York, Columbia Univ. Press, $142 \mathrm{p}$.

Klemic, Harry, 1962, Uranium occurrences in sedimentary rocks in Pennsylvania: U.S. Geol. Survey Bull. 1107-D, p. 243-287.

Klemic, Harry, and Baker, R. C., 1954, Occurrences of uranium in Carbon County, Pennsylvania: U.S. Geol. Survey Circ. 350,8 p.

Krynine, P. D., 1948, The megascopic study and field classification of sedimentary rocks: Pennsylvania State Coll. Mineral Industries Expt. Sta., Tech. Paper $130,165 \mathrm{p}$.

Lesley, J. P., 1885, A geological hand atlas of the sixty-seven counties of Pennsylvania: Pennsylvania 2d Geol. Survey Rept. 10, 112 p., maps. 
Lohman, S. W., 1937, Ground water in northeastern Pennsylvania: Pennsylvania Geol. Survey, 4th ser., Bull. W4, 300 p.

McCauley, J. F., 1957, Preliminary report on sedimentary uranium occurrences in the State of Pennsylvania: Pennsylvania Geol. Survey, 4th ser., Progress Rept. 152, $22 \mathrm{p}$.

McLaughlin, D. B., 1944, Triassic stratigraphy in the Point Pleasant district, Pennsylvania: Pennsylvania Acad. Sci. Proc., v. 18, p. 62-69.

Montgomery, Arthur, 1954, Uranium minerals of the Mauch Chunk area, Pennsylvania: Pennsylvania Acad. Sci. Proc., v. 28, p. 102-110.

Pennsylvania Bureau of Topographic and Geological Survey, 1960, Geologic map of Pennsylvania.

Read, C. B., 1955, Floras of the Pocono formation and Price sandstone in parts of Pennsylvania, Maryland, West Virginia, and Virginia: U.S. Geol. Survey Prof. Paper 263, 32 p., 20 pls.

Rogers, H. D., 1836, First annual report of the State geologist: Harrisburg, Pa., 22 p.

Smith, A. D. W., 1895, Report on the anthracite region: Pennsylvania 2d Geol. Survey Final Rept. 3, pt. 1, p. 1916-2152.

Stieff, L. R., and Stern, T. W., 1961, Graphic and algebraic solutions of the discordant lead-uranium age problem: Geochim. et Cosmochim. Acta, v. 22, p. 176-199.

Stern, T. W., Stieff, L. R., Klemic, Harry, and Delevaux, M. H., 1960, Leadisotope age studies in Carbon County, Pennsylvania, in: Short papers in the geological sciences: U.S. Geol. Survey Prof. Paper 400-B, p. B45-B48.

Stevenson, J. J., 1902, Notes on the Mauch Chunk of Pennsylvania: Am. Geologist v. 29, p. 242-249.

Stose, G. W., and Ljungstedt, O. A., 1931, Geologic map of Pennsylvania: Pennsylvania $2 \mathrm{~d}$ Geol. Survey.

U.S. Weather Bureau, 1930, Climatic summary of the United States: Climatography of the United States: no. 10-89.

1958, Climatic summary of the United States-supplement for 1931 through 1952: Climatography of the United States, no. 11-32.

Wherry, E. T., 1912, A new occurrence of carnotite: Am. Jour. Sci., 4th ser., v. 33, no. 198 , p. $574-580$.

1915, Carnotite near Mauch Chunk, Pennsylvania: U.S. Geol. Survey Bull. 580, p. 147-151.

White, C. D., 1900, The stratigraphic succession of the fossil floras of the Pottsville formation in the southern anthracite coal field, Pennsylvania: U.S. Geol. Survey 20th Ann. Rept., pt. 2, p. 749-930.

1934, The age of the Pocono: Am. Jour. Sci., 5th ser., v. 27, p. 265-272.

White, I. C., 1881, The geology of Susquehanna County and Wayne County: Pennsylvania 2d Geol. Survey Rept. G5, 243 p., map.

1882, Geology of Pike and Monroe Counties: Pennsylvania 2d Geol. Survey Rept. G6, 407 p., map.

Willard, Bradford, 1935, Portage group in Pennsylvania: Geol. Soc. America Bull., v. 46, no. 8, p. 1195-1218.

- 1936, Continental upper Devonian of northeastern Pennsylvania: Geol. Soc. America Bull., v. 47, no. 4, p. 565-608.

- 1939, The Devonian of Pennsylvania: Pennsylvania Geol. Survey, 4th ser., Bull. G19, 481 p.

- 1957, Devonian section near Bowmanstown, Pennsylvania: Am. Assoc. Petroleum Geologists Bull., v. 41, no. 10, p. 2298-2311. 


\section{GEOLOGY AND URANIUM OF LEHIGHTON QUADRANGLE}

Winslow, Arthur, 1887, The Lehigh River section: Pennsylvania 2d Geol. Survey Ann. Rept., pt. 4, p. 1363-1371.

Wood, G. H., Jr., Trexler, J. P., Arndt, H. H., Yelenosky, Andy, and Soren, Julian, 1956, Subdivision of Pottsville formation in Southern anthracite field, Pennsylvania: Am. Assoc. Petroleum Geologists Bull., v. 40, no. 11, p. 2669-2688.

Yoder, H. S., and Eugster, H. P., 1955, Synthetic and natural muscovites: Geochim. et Cosmochim. Acta, v. 8, p. 225-280. 


\section{INDEX}

[Where several page numbers appear, major references are in italic]

A

Accessory minerals

$18,27,30,32,35,49,51,54,78$

Acknowledgments.

Analomink red shale

Andersonite.

Anthracite coal.

Arkose.

Autunite.

Azurite.

Background radioactivity

Bald Mountain

Bald Mountain anticline

Bald Mountain-Unionville anticline

Bear Creek $3,26,32,33,35,37,38,42,43,62$

Bear Mountain $26,29,68$

Beaverdam Run

Beaverdam Run member........ 10, 13, 14, 19, 23,
$27,28,30,57,62,63,64,65,68,73,74,75$

Beds, overturned

$27,28,30,57,62,63,64,65,68,73,74,75$

Bedding-plane slippage

$56,60,61,62,63$

Bedding-plane slippage, faults, and drag folds.

Berry Run

Betauranophane

Blbliography

Big Creek

Bioherms

$10,13,58,69$

Black Creek

$5,43,51,59$

Black ore 85,90

Broad Mountain

$5,42,43,56,59,68$

Broad Mountain anticlin $5,59,71,77,81,89$

Butcher Hollow

$59,77,82$

Butcher Hollow uranium occurrence

C

Call Mountain $3,5,30,32,56,58,76$

Carnotite 85,90

Carpsrocus Creek

Catskill formation....... 9,10,13,14, 15, 19, 26, 28, 30, $33,37,54,57,58,59,60,62,68,69,70,73,75,77,79$, $81,82,83,88$.

Centerfield coral zone

Centerfield limestone

Chalcopyrite 10

Chemical analyses............... 7,80

Chemung series

Chemung time

Cherry Ridge redbed member ... 13, 19, 20, 30, 31; 32 , $33,37,59,61,75,77,81,82,83,88,89$

Clausthalite $67,79,83,85,87,88$ -Clay mineral fractionations
Page

Clay-size mineral components............. 12

Cleavage................................... 56, 61,65

Climate and vegetation....................... 6

Coal

Colorado Plateau............................ 77

Conglomerate, red matrix.................. 35

Copper minerals........................... 91

Cross Run................................... 59

D

Damascus redbed member.................... 13,

$19,22,27,28,29,30,31,63$

Delaware River flags......................... 14

Devonian age, Late.................. 13, 19, 69, 73, 77 Middle_....................................... 72,73

Devonian formations........................ 8,

Devonian sediments........................ 71

Devonian series, Middle....................... 10

Upper............................... 9, 13, 26

Distribution and extent of radioactive rock.-. 79

Drag folds....................................... 57,61, 65

bedding-plane slippage, and faults........ 61

Drainage........................................... 5

Drakes Creek $\ldots . . . \ldots \ldots$

Drakes Creek syncline........................ 60

\section{$\mathbf{E}$}

Ellipsoidal structures......................... 68,87

Engler Run ............................. 33

Faults............................ 56, 57, 60, 61, 63, 64 drag folds, and bedding-plane slippage...-. 61

Field and laboratory methods................ 7

Fish or shark spine......................... 75

Flow cleavage

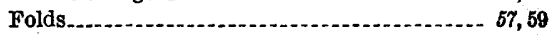

Fort Littleton formation, Trimmers Rock member........... 9

Fossils, marine....................... 27, 68,73, 75

Fracture cleavage............................. 61,65

Fractures_...................... 61, 63,67

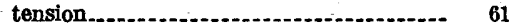

Francolite

\section{G}

Galena.............. 68, 88, 90, 91

Galena, sphalerite, chalcopyrite and pyrite _... $\quad 90$

Geochronology

Geologic history................................ 69

Glacial features........... 5

Graywacke, low-rank ................... 18 ,

$27,29,31,34,41,48,50,77,83$ 


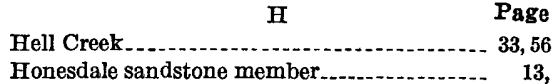

$19,21,22,29,30,35,36,63$

Hydrothermal solutions

\section{I}

Illinoian drift 86,87

Illinoian glacial stage.

Index fossil.

Indian Hills.

Isotopic composition of galena.

\section{$J$}

Jerseyan drift

Jerseyan glacial stages

Jim Thorpe . ................................. $5,6,8,26,32,33,37,40,43,44,51,59,77,81,82,83$ Joints . . . . . . . . Joint sets................................. 56, 58, 72

Julian Spring. 35

$\mathbf{K}$

Kasolite $61,64,66,67,79,80$

Keipers Run

Kettle Hill

Kresgeville

L

Larrytown syncline

Lead and uranium isotope ratios

Lehigh River. $5,6,8,9,14,15,26,28,29,31,32,33,35,36,37,43$, $44,47,51,52,56,57,59,61,62,65,66,72,75,76$, $77,80,82,83,89,92$.

Lehighton. 3,57

Lehighton anticline............. 5, 19, 27, $57,62,65,66$ overturned beds overturned north limb

$5,19,27,67,62,65,66$

Leslie Run

Liebigite.

Little Bear Creek

Little Bear Creek

33,58

Iocation and accessibility.................. 3

Low-rank graywacke - $18,27,29,31,34,41,48,50,77,83$

Ludlow ville facies.

\section{$\mathbf{M}$}

Mahantango formation.

Malachite

Marcellus and Hamilton formations, undivided...................... $9,10,11$, $12,13,15,19,30,57,58,63,65,72,73,75$

Marine fossils .............................. 27, 68,73

Matrix minerals...................... 18, 27, 32,49,66

Mauch Chunk.

Mauch Chunk formation................... 10, $37,44,52,58,60,61,63,68,71,92$ main body of red beds.

Mauch Chunk Ridge ...................... 20,

$21,30,32,35,42,43,77,81,83,91$

Mauch Chunk Ridge uranium occurrence.... 76, $77,89,88,90$

Mauch Chunk-Pottsville transition zone..... 44, $45,49,54,68,71,83,88,89$
Page

Meta-autunite

Metamorphism.............................. 69

Metatorbernite

Metauranocircite

Millstone Mountain ........................... 56, 60

Mineral resources.

Mississippian age........................... 70

Mississippian formations................... 8, 71, 88

Mississippian-Pennsylvanian boundary _...-- 10

Mississippian series, Lower................... 37

Upper............ 44

Moscow facies.................... 10

Mount Pisgah $\ldots \ldots \ldots$ 44, 45, 47, $49,51,52,53,54,55,58,62,63,68,76,83,85,86$ Mount Pisgab uranium occurrence.......... 76 ,

$89,85,87,88,90$

Mount Pisgah-Call Mountain syncline _..... . 58, 83 Mud Run_...................... 5, 35, 36, 43, 52, 61, 92 Mud Swamp................................. 35

N

Nesquehoning

Nesquehoning Creek.

New Milford red shale....................... 14

o

Origin of uranium occurrences.......... $85,86,87,89$

\section{$\mathbf{P}$}

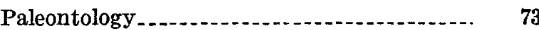

Panther Creek. .............. 5, 35, 56, 60

Panther Valley syncline .................... 58

Penn Haven Junction .................. 5, 7, 36, 40, $43,51,52,59,60,67,68,77,81,87,88,89,92$ Penn Haven Junction uranium occurrences... $\quad 75$, $76,77,79,82,84,86,87,88,89,90$ Pennsylvanian age ..................... 52,54,70, 91 Pennsylvanian formations, lower............. 8 Pennsylvanian rocks........................ 71, 72 Pennsylvanian system............... 52 Pennsylvanian time......................... 72,87 Pennsylvania Turnpike.................. 3 , $15,16,23,24,56,57,62,64,90$ Permian rocks Piedmont province..... 71 Physiography .................... 3 Pine Creek

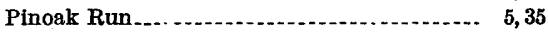
Pleistocene and Recent surficial material..... 55 Pleistocene time......... 72 Pocono formation ............................ 8,10, $13,19,33,35, s 7,44,59,60,61,62,68,70,71$ Pocono Plateau.......................... 3, 32, 56,61 Pocono-Catskill contact.................... 42 Pocono Mountain ...................... 7, 43, 56 Pocono Plateau escarpment................... 59 Pohopoco Creek .............. 5, 11, 13, 19,65 Pohopoco Mountain ........... 3, 5, 33, 35, 55, 56, 59, 61 Portage group of Willard............... 9,14,15 Post-Pennsylvanian age ...................... 91 Post-Pottsville rocks.................... 54, 70, 71, 72 Pottsville formation.... $8,10,44,47,50,52,55,70,71$ Previous geologic work....................... 8 Purpose and scope of investigations........... 
Quartz crystals

\section{Q}

Quartz pebble conglomerate

Quartzite

Quartzitic sandstone

Quaternary

Quaternary glaciers

Quaternary glacial material

$\mathbf{R}$

Radioactive rock $77,79,80,82,83,84$

Radiometeric analyses..

Recent and Pleistocene surficial material

Recent time.

Relief of stress during folding.

Roll structures

s

Schooley peneplane

Schroeckingerite

Scrub Mountain

Selenium

Sequence of deposition of minerals

Silkmill Run

Silurian formations

Skaneateles facies

Slate.

Spectrographic analyses

Sphalerite

Starrucca sandstone

Stone and slate

Stony Creek

Stony Creek syncline

Stony Ridge

Stratigraphic nomenclature

Stratigraphy

Structure

Summer Mountain

Summer Mountain anticlin

Susquehanna group

Susquehanna series of Ashley

Syncline near Jonesville.

$\mathbf{T}$

Tertiary lead deposits

Thin sections of uraniferous rock

Thorium

Torbernite
Triassic rocks.

Page

Trimmers Rock member, Fort Littleton formation.

9

Trimmers Rock sandstone ............. 10,11,13,

$14,15,19,28,57,58,62,63,65,68,69,73,74,75,90$

Tully formation .............................. 11, 73

Tumbling Run member, Pottsville formation. 10

Type section, Cherry Ridge redbed member..

Pocono formation ........................ 37

Walcksville sandstone member........... 26

Tyuyamunite . ........

\section{U}

Unidentified uranium mineral................ 84

Upper Wild Creek-Jonas anticline............. 59

Uraniferous rock ....................... 33, 35, 36,

Uraninite_......................... 67,77,78, 79, 83, 87

Uranium ....... 8 $8,59,75,76,77,78,81,82,85,87,89,90$

Uranium minerals, secondary _- $79,80,82,83,84,85,89$

Uranium occurrences..... $2,47,60,68,76,77,85,86,89$

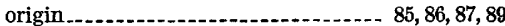

Uranium potential............................ 88

Uranophane.............................. 79, 83,

V

Valley and Ridge province................... 3,56

Vanadium

W

Walcksville sandstone member .......... 10 $13,14,15,19,24,26,27,28,57,62$

Water resources.............................. 76

Wild Creek $\ldots \ldots \ldots \ldots, 13,18,57,58,59,65,76$

Wild Creek reservoir....................... 6

Willard's Mahantango formation.............. 10

Wisconsin-age drift

Wisconsin glacial stage ................... 6

Wisconsin glacial till. . ........................ 56

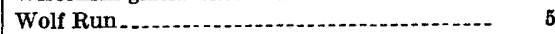

\section{$\mathbf{X}$}

X-ray spectrometer analyses................. 7, 19,79

\section{$\mathbf{Y}$}

Yellow Run

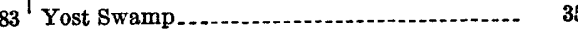


The U.S. Geological Survey Library has cataloged this publication as follows:

\section{Klemic, Harry, 1920-}

Geology and uranium occurrences of the northern half of the Lehighton, Pennsylvania, quadrangle and adjoining areas, by Harry Klemic, James C. Warman, and Alfred R. Taylor. Washington, U.S. Govt. Print. Off., 1963.

v, 96 p. maps (2 fold. col. in pocket) diagr., tables. $24 \mathrm{~cm}$. (U.S. Geological Survey. Bulletin 1138)

Prepared on behalf of the U.S. Atomic Energy Commission.

Bibliography : p. 92-94.

(Continued on next card)

Klemic, Harry, 1920-

Geology and uranium occurrences of the northern half of the Lehighton, Pennsylvania, quadrangle and adjoining areas. 1963. (Card 2)

1. Geology-Pennsylvania-Carbon Co. 2. Uranium ores-Pennsylvania-Carbon Co. 3. Ore-deposits-Pennsylvania-Carbon Co.

I. Warman, James C., 1927- , joint author. II. Taylor, Alfred Raleigh, 1928- , joint author. III. Title: Lehighton, Pennsylvania, quadrangle. (Series) 